\title{
Kernos
}

Revue internationale et pluridisciplinaire de religion grecque antique

$29 \mid 2016$

Varia

\section{Epigraphic Bulletin for Greek Religion 2013 (EBGR 2013)}

\section{Angelos Chaniotis}

\section{(2) OpenEdition \\ Journals}

Electronic version

URL: http://journals.openedition.org/kernos/2402

DOI: 10.4000/kernos.2402

ISSN: 2034-7871

\section{Publisher}

Centre international d'étude de la religion grecque antique

Printed version

Date of publication: 1 October 2016

Number of pages: 269-316

ISSN: 0776-3824

\section{Electronic reference}

Angelos Chaniotis, « Epigraphic Bulletin for Greek Religion 2013 (EBGR 2013) », Kernos [Online], 29 |

2016, Online since 01 October 2018, connection on 17 November 2020. URL : http://

journals.openedition.org/kernos/2402 ; DOI : https://doi.org/10.4000/kernos.2402

This text was automatically generated on 17 November 2020 .

Kernos 


\title{
Epigraphic Bulletin for Greek Religion 2013 (EBGR 2013)
}

\author{
Angelos Chaniotis
}

1 Continuing the practice that I have adopted in the last years, in this 26th issue of the EBGR I have placed emphasis on the presentation of corpora, new finds, and new readings, restorations, and interpretations rather than on publications that are dedicated to religious phenomena and adduce inscriptions. In addition to new finds published in 2013, I have made some additions to earlier issues (publications of 20082012).

2 This issue summarizes the content of important corpora from Dodona (37) and Ankyra (75), a useful collection of inscriptions from Olympia that were found after the publication of $\mathrm{IVO}$ (107), and large groups of inscriptions from the sanctuary of Demeter and Kore in Corinth (110)), Mysia (114), and Phrygia and Lykaonia (118). The oracular tablets from Dodona constitute the most important epigraphic material published in 2013; despite some weaknesses in the publication, these texts will greately contribute to the study of Greek divination, religion, and religious mentality. Among the new texts, I mention a dedication from the Kibyratis which attests a divine triad, Herakles/ Kakasbos, his newborn son Hosios kai Dikaios, and the Golden Maiden (35). Other significant finds include inscriptions that mention Tiripates, a young Anatolian god (61), the cult of Ge Kataphyge (80), the cult of Pantheion (114), and the introduction of the cult of a 'new hero' (114).

3 The principles explained in Kernos 4 (1991), p. 287-288, and Kernos 7 (1994), p. 287, also apply to this issue. Abbreviations that are not included in the list are those of L'Année Philologique and J.H.M. STRUBBE (ed.), Supplementum Epigraphicum Graecum. Consolidated Index for Volumes XXXVI-XLV (1986-1995), Amsterdam, 1999, as well as of later volumes of the SEG. If not otherwise specified, dates are BCE. Matthew Peebles (Columbia University) has improved the English text. 


\section{Abbreviations}

\begin{tabular}{|c|c|}
\hline AST 28 & 28. Araştırma Sonuçları Toplantısı. 24-28 mayis 2010, Istanbul, Ankara, 2011. \\
\hline $\begin{array}{l}\text { Cities and } \\
\text { Priests }\end{array}$ & $\begin{array}{l}\text { M. HORSTER and A. KLÖCKNER (eds.), Cities and Priests. Cult Personnel in Asia Minor and } \\
\text { the Aegean Islands from the Hellenistic to the Imperial Period, Berlin, } 2013 .\end{array}$ \\
\hline Hymnes & $\begin{array}{l}\text { R. BOUCHON, P. BRILLET-DUBOIS, N. LE MEUR-WEISSMAN (eds.), Hymnes de la Grèce antique. } \\
\text { Approches littéraires et historiques. Actes du colloque international de Lyon, 19-21 juin } \\
\text { 2008, Lyon, 2012. }\end{array}$ \\
\hline KST 32 & 32. Kazi Sonuçlari Toplantısı. 24-28 mayis 2010, Istanbul, Ankara, 2011. \\
\hline Stephanèphoros & $\begin{array}{l}\text { K. KONUK (ed.), Stephanèphoros. De l'économie antique à l'Asie Mineure. Hommages à } \\
\text { Raymond Descat, Bordeaux, 2012. }\end{array}$ \\
\hline
\end{tabular}

\section{Selected Topics}

\section{Geographical areas (in the sequence adopted by SEG)}

Attika: Athens 7. 23-25. 29. 43. 60. 67-68. 74. 104. 109. 112. 117. 121. 128; Eleusis 24. 85; Piraeus 14. 93. Peloponnese: Corinthia: Corinth 15. 110; Kenchreai 100. Argolis: Argos 15. 64. 92. 95. 117; Hermione 24; Mykene 49. Troizenia: Troizen 25. 48. Epidauria: Epidauros 46. 97. 127. Lakonia: Sparta 62. Messenia: Messene 66. 78. 115-116; Thalame 40; Thouria 10-11. Arkadia: Phigaleia 12. Elis: Olympia 32. 65. 72. 79. 107. Megaris: Megara 13. 126. Boiotia 54; Akraiphia 97; Thebes 53-55; Thespiai 103. Delphi 104. Phokis 59; Antikyra 101. Thessaly: Demetrias 120; Larisa 122; Pherai 24. Epirus: Dodona 37. 94. Dalmatia 70. Macedonia 130; Aiane 97; Amphipolis 38; Dion 118. Thrace 108; Augusta Traiana 56. Moesia Histria 86. North Shore of the Black Sea: Olbia 18. Delos 3. Rhodes 50; Lindos 91. Anaphe 87. Thera 31. Kos 26. 31. 57-58. 78. 111. Naxos 71. Paros 88-89. Siphnos 90. Amorgos: Minoa 69. Euboia: Eretria 117. Crete 33. 124; Palaikastro 27. Italy: Caere 17; Rome 20. Sicily: Tauromenion 77. Sardinia 21. Malta 26. Moesia superior: Viminacium 63. Asia Minor: Karia: Aphrodisias 78; Gergakome 52; Halikarnassos 25. 31. 41; Iasos 19; Knidos 28. 97; Labraunda 9; Lagina 3. 119; Mylasa 3. 96. 117; Nysa 98; Panamara 3; Stratonikeia 78; Tralleis 42. 51. 66. Ionia: Ephesos 61. 66. 73. 99; Erythrai 3; Klaros 39. 76; Kolophon 39; Magnesia on the Maeander 51; Miletos 3. 30. 117; Priene 78. 97. Lydia 99; Philadelpheia 66. Troas Alexandreia/Troas 117. Mysia 114; Kyzikos 81. 97. 117. Bithynia 16; Hadrianoi 16. 83; Nikomedeia 5. Galatia Ankyra 75; Germia 129. Phrygia 118; Aizanoi 66; Akmonia 47; Hierapolis 102; Motella 97; Phaselis 123. Pisidia Antiocheia 6; Hadrianoi 80; Komana 36. Lykia 4. 106; Arykanda 125; Kibyra 34-35; Myra 84; Neisa 113; Patara 22. Lykaonia 118. Isauria 44. Kilikia 82. Cyprus 64. 73. 105. Syria: Emesa 8. Arabia: Epiphaneia 53. Egypt: Alexandria 1. 66. 73. 105.

afterlife 24.97.121 

116 (Tegea); Alexandreia kai Antiocheia 76 (Ionian Koinon); Antigoneia 116; Antonieia 117 (Athens); Asklepieia 75 (Ankyra). 118 (Akmonia); Aspis 64. 111 (Argos); Augusteia Aktia 75 (Ankyra); Basileia 116; Dionysia 7. 74 (Athens); Eleusinia 116; Eleutheria 116; Epitaphia 68 (Athens); Euergesia 117 (Asia); Hekatombaia 64 (Argos); Heraia 64.116 (Argos); Isthmia 111. 116; Isthmia kai Kaisareia 15 (Corinth). 116 (Messene); Klaria 39. 76; Klaudeia 111 Rhodes; Koina 111 (Asia, Macedonia, Thessaly); Lykaia 111. 116; Marcellia 117 (Syracuse); Moukieia 117 (Asia); mousikos agon 75 (Ankyra); Mouseia 103 (Thespiai); Naia 94. 116 (Dodona); Nemea 111. 116; Olympia 79. 107. 116; Pythia 116; Smintheia Pauleia 117 (Alexandreia/ Troas); Soteria 116-117; Sulleia 117 (Athens); Thargelia 23. 67 (Athens); Titeia 117 (Argos) altar 9. 16. 30. 36-37. 40. 69.114. 118. 129; domestic 16.105; shared by several gods 75 amulet 45.66

anatomical votive 118

ancestors 55

angel 66

animal see s.v. cat, dolphin, eagle, snake

Arsinoe Philadelphos 41. 105

association, cult 3.30.81. 108; of technitai 38

asylia 66

banquet 25. 57.75

bath 3

Bellerophontes 25

body-soul 8

calendar 64; sacrificial c. 112

cat 1

cave 51.59

choregia 23.67

Christianity, use of pagan expressions by 118

cleromancy 37

crime, and religion 37

cult, endowment of 57; finances of 57; of benefactor 117-118; of Roman official 117; see also s.v. hero cult, imperial cult, ruler cult

cult personnel agonothetes 15-16. 75. 99. 104. 116. 118; alytarches 107; alytas 107; amphipolos 37; archeuo 57; archiereia of the imperial cult 118; in Asia 4; in Galatia 75; in Lykia 22. 113; archiereus of the imperial cult 107; in Asia 118; in Athens 104; in Galatia 75; in Lykia 113; archineokoros 119; athlothetes 64; bouzyges 104; dadouchos 104; epimenios 31; epispsondorchestes 107; exegetes 107; hagnistes 103; Helladarches 75; hiereia 3. 34. 66. 78. 90. 99. 110. 118; hiereus 3. 5. 16. 29. 31. 36. 38. 47. 51. 57. 60. 78. 86. 90. 104. 107. 113-116; of the civic imperial cult 22; hieromnamon 37. 49. 64; hierophantes 37. 75. 104; hieropoios 26; hierourgos 75; kouretes 118; mantis 37. 107; neokoros 35. 75. 110; neopoios 66. 99; panegyriarches 16. 118; prophetes 16.83 ; propolos 25; sebastophantes 75 ; spondaules 107; 
spondophoros 107; theokolos 107; thoinarmostria 116; thyoskoos 37; zakoros 112; see also s.v. priest, priesthood

cult regulation 11. 16. 19. 40. 71. 104. 107. 112

curse, see s.v. imprecation

curse tablet 20.93.100.110

Damaskios 8

death 8.118

dedication, negotiation for 37; label on 59.94

dedication, agent of official 104; priest 35. 36. 60. 66. 114. 118; priest/priestess after his/ her term in office 18. 39. 103; slave 114; soldier(s) 70.73.82; victor in contest 94.111

dedication, motives for: after a dream 63. 97; after war 49-50; for well-being of family members 88. 114. 129; in accordance with oracle 50; thanksgiving 62; upon divine command 16; see also Greek words

dedication, object of: column 16. 39; disk 32; dolphin pillar 30; incense burner 21; sundial 54; throne 62; torch 109; vases 107; weapons 49. 107; cf. s.v. anatomical votive

defixio see s.v. curse tablet

deities Aion 104. Amynos 104. Aphrodite 26. 34-35. 37. 66. 75. 116. Apollo 16. 37. 51. 52. 66. 104. 111-112. 127; Apotropaios 126; Asgelatas 87; Chalazios 64; Delios 89; Delphinios 30; Enagros 64 Ergates 64; Erithaseos 64; Erithaseus 64; Erithios 64; Erythibios 64; Genetas 103; Horites 64; Horomedon 64; Karneios 28; Klarios 39. 76; Lairbenos 97; Mylantios 64; Paianios 114; Parnopios 64; Pasparios 64; Propylaios 118; Ptoios 97; Pythios 23; Sitalkas 64; Smintheus 64; Thargelios 64; Thoraios 64. Ares 50. 60. 75. Aristeus 118. Artemis 35. 37. 66. 78. 92. 99. 107. 114; Alphiaia 110; Delia 89; Eileithyia 103; Elaphebolos 70; Klaria 76; Kynegetis 106; Orthosia 50; Soteira 69. Asklepios 10-11. 16. 75. 88. 97. 104. 118. 127; Kyrios 129; Paianios 114; Soter 129. Athena 12.37-38. 47. 101. 110. 116; Areia 50. 60; Korra? 12; Lindia 91; Pallas 127. 129; Polias 37; Soteira 50. Basileus 75. 107. Basilissa 75. Baubo 24. Charites 114. Daimon Agathos D. Pater 75. Demeter 24. 37. 46. 58. 65-66. 75. 78. 97. 104. 107. 110. 115116; Chamyne 65; Chthonia 24. Dikaios kai Hosios 35. Diktynna 33. 39. Dione 37. Dionysos 3. 17. 53. 75. 81. 107-108. 110. 112. 116. 118; Helios D. 114; Karpophoros 86; Kathegemon 114. Dioskouroi Soteres 75. Eileithyia 128; Artemis E. 103. Elpis 35. Ennodia 37. Enyalios 49-50. Enyo 50. Eubouleus 24. Eukles 24. Ge 24. 110; Kataphyge 80. Hades 24. Hekate 3. 6. 112. 114. 119. Helios 54; H. Dionysos 114; Zeus H. Sarapis 75. Hera 3. 37. 64. 66. 72. 92. Herakles 26. 35. 37. 50. 77. 107; Archegetes 26. Hermaphroditos 25. Hermes 13-14. 26. 47. 68. 75. 77. 97; Chthonios 110. 122. Hestia 37. 66. Horai 114. Hygieia 10-11. 16. 48. 75. 88. 104. 118. 127; Kyria 129. Kore 24. 35. 65. 78. 97-98. 104. 107. 110; Neotera 110. Korybantes 3. Kouretes 25. 33. 118. Kybele 24. 52. 61. 97. Leto 35; Meter 118. Meter 24. 61. 118; Hagia 61; Karia 52 Oreia 24; Patroia 61; Phrygia 19; Tetraprosopos 118. Meter Theon 19. 36. 46. 75. 120; Epekoos 36. Muse 35. Nemesis/ Nemeseis 114. 118. Nike 35. 50. Nymphs 37. 43. 59. 118; Oceanids 42. Paian 110. Pan 59. 97. 107. Pantheion 47. 114. Parthenos Chrysea 35. Pasiphae 62. Persephone 24. 110. Plouton 97. 98. 104; Basileus 65. 107. Poseidon 37; Asphaleios 50. 114; Helikonios 76. Potamos 114. Protogonos 24. Rhea 37. Salmakis 25. Selene 75. Thea Rhome 75-76. Themis 37. Theoi Dodeka 106; Megaloi 116; Patrioi 75. Theos Hypsistos 80. 118. Tyche 37. 75. Tritopatreis 55. Zeus 3. 25. 27. 33. 37. 46. 75. 104. 106-107. 114. 118; Akouseos 118; Alsenos 118; Ampelites 27; Anadotes 27; Bouleus 24; Chamonaios 37; Demetrios 27; Dodonaios 
37; Dodoneus 37; Epekoos 34; Epidotes 27; Eubouleus 24; Helios Sarapis 75; Homoloios 122; Hyetios 27; Hypsistos 118; Ithomatas 115-116; Kataibates 40. 88; Keraunios 47. 82; Kersoullos 16; Kretagenes 39; Ktesios 16. 27; Labraundos 9; Megas 118; Megistos 28. 75. 118; Naios 37; Olympios 32. 107; Ombrios 27; Oporeus 27; Pandemos 114; Patrios 118; Phytalmios 27; Pronaios 37; Soter 12. 50; Stratios 118

deities, Anatolian Angdistis 118; Kakasbos 35; Meter Amlasezene 118; Meter Zizimene 118; Tiripates 61; Zeus Salarameus 118

deities, Egyptian 73; Boubastis 1; Isis 37. 73. 75; Sarapis 75

deities, Iranian Mes 75. 118. 129; Ouranios 75

deities, Oriental Atargatis 3; Attis 118

deities, Phoenician 26; Melquart 26

deities, Thracian Thracian Rider 56

deity, birth of 25. 35. 118; conflict between gods 46; epiphany in dream 97. 114; facial expression 97; patron of family 103; patron of fertility 27. 64; patron of water 27; river god 114; taboo on name of god 24; tribe named after d. 75; victory in athletic contest given by a god 79. 107; see also c.v. epiphany

deme, cult 7.57. 112

Dionysiac technitai 38.75

disease 37. 66. 118; as divine punishment 37; see also s.v. healing

divination 37.62.66.97; see also s.v. necromancy, oracle, sign

dolphin 30

double-axe 118

dream 97. 114. 129

eagle 130

ear 120

earth-born 25

Eleusis, cult in 24.85

endowment 57

Endymion 25

epiphany 76. 91; epiphanic dream 97

euergetism 3

family 3.31

fertility 7

festival 90. 116; Asgelaia 87; Erithaiea 64 (Argos); Thesmophoria 24. 118; see also s.v. agonistic festival

festival, finances of 64

food offering 112

foundation, of city 25. 55; cult f. 31.114

funerary cult 37. 99. 114. 118. 121-122. 125; funerary relief dedicated to the gods 84; cenotaph 97 


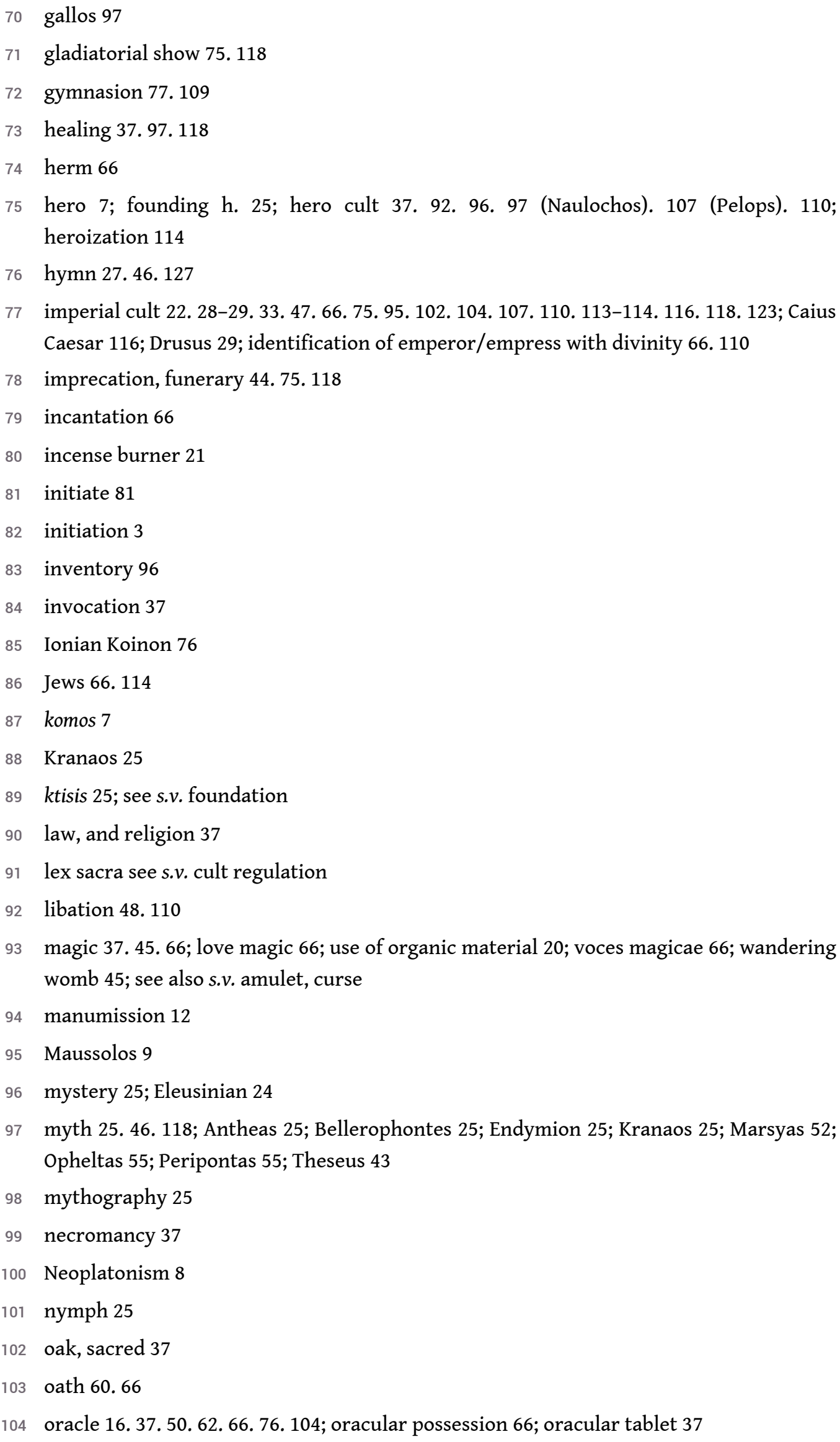


Orphism 24.124

piety 47

poetry 25

pollution 37 (hiereia, hiereus)

propitiation 37

reform 58

river god 114

Sibylla 37

sign, divine 76

snake 16.118

song 110

soul 8.118

spring 25 37

personification see s.v. deities (Aion, Elpis, Nike)

prayer 1.37.56. 66; prayer for justice 100. 110; prayer for the soul 118

priest, crowing of 38 ; family of 4 ; honorific statues for 78 ; see also s.v. cult personnel

priesthood 37. 57; appointment 57; appointment by lot 57-58; demoteles 90; elite and p. 57 ; eponymous 86 ; for life 19.36 .47 .75 .118 ; iteration 75 ; jointly held by man and woman 3. 99; jointly held by couple 3. 75 . 113; jointly held by family members 99; marital status 66; perquisites 19. 31; sale of 19. 57-58

procession 19. 75-76

punishment, divine 37

purification 3. 91; purifier 103

purity 24 ; moral p. 102

Pythagoreans 66

rhapsodos 94.118

rituals, see s.v. banquet, initiation, libation, mystery, procession, purification, sacrifice, theoria, theoxenia; vow; see also Greek words

ruler cult 9. 41. 73. 90. 105; joint dedication to kings and gods 73

sacrifice 7. 11. 19. 37. 40. 75-76.112. 116; sacrificial calendar 112

sacrilege, theft of sacred money 37; theft of statue 37

sanctuary 51-52; administration of 39; banking activities 64; boundary stone of 52. 8889. 110; federal 33; finances 64; privileges of 39; leasing of offering tables 98; prohibition against animals 71; recipient of fine 12; restoration of 104; revenues 64. 98; sacred land 37; sacred money 33. 37 ; subsidiary cult in 92

statue 16. 47. 72. 78. 91. 107. 114. 116; appearance of a god in a dream in the form of his statue 97 ; crowning of 75 ; falling in love with s. 91 ; sacrifice in front of s. 116; stealing of

statuette 1.6.36.65.107 
table, offering 98

temple 35. 118; death in 91; opening of $t$. during festival 90

theoria 37.76

theoxenia 104

Theseus 43

torch-race 109

tree, see s.v. oak

vision 97. 114

vow 1.75. 82.114.118.129. 130

water 25

woman 45

\section{Greek Words (a Selection)}

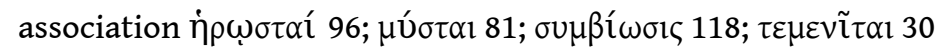

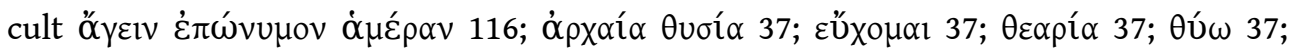

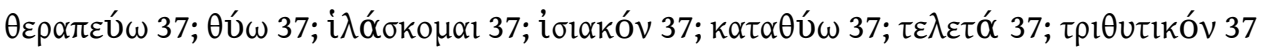

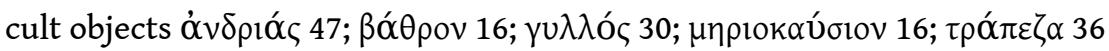

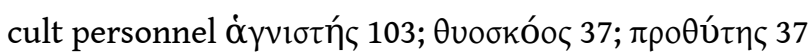

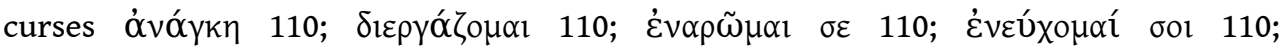

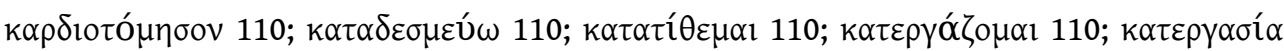

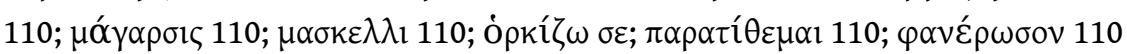

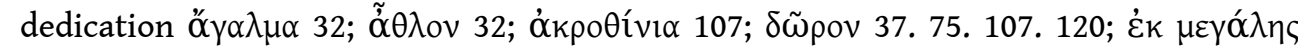

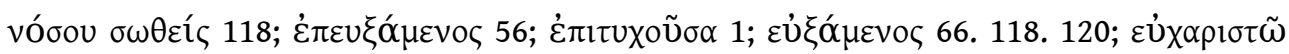

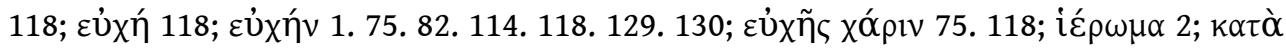

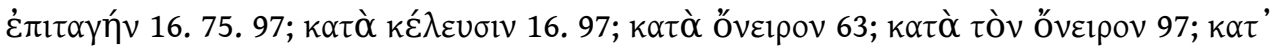

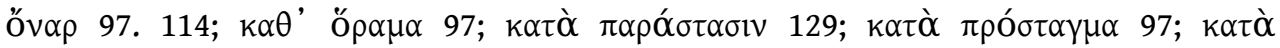

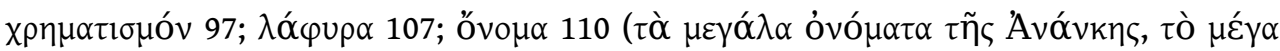

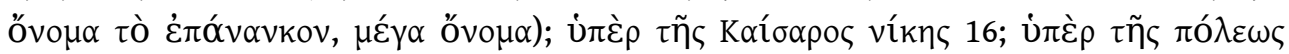

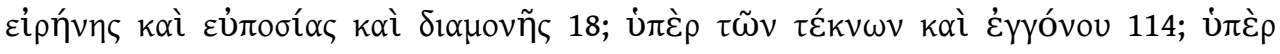

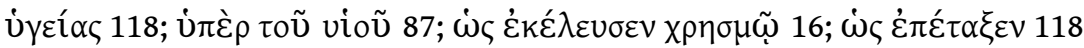

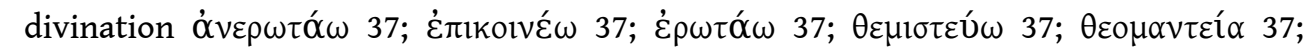

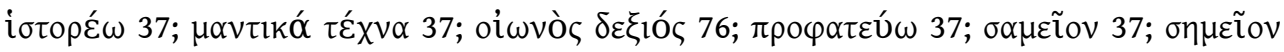

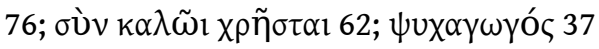

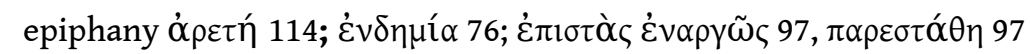

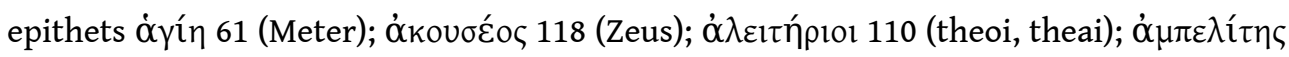

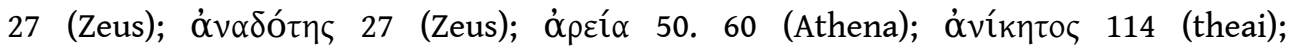

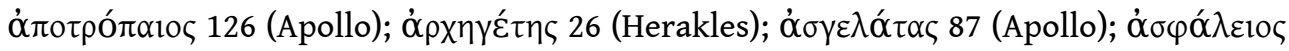

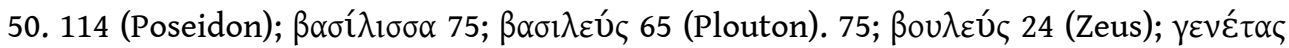

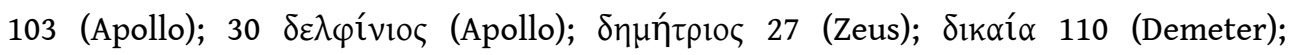

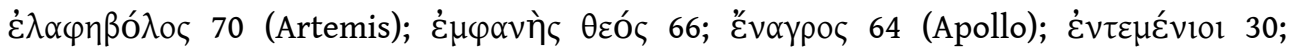
$\dot{\varepsilon} \pi \eta ́$ кооৎ 35. 56; 2. 36 (Meter Theon). 34 (Zeus). 75 (Asklepios, Hygieia, Basilissa, 


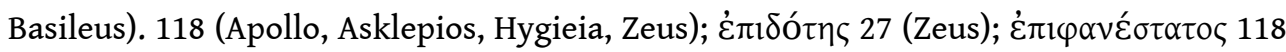

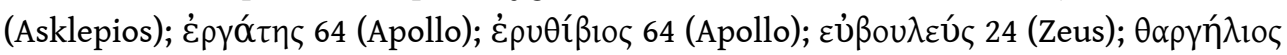

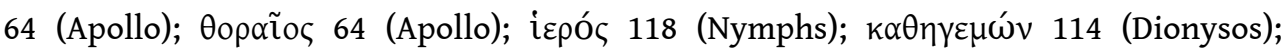

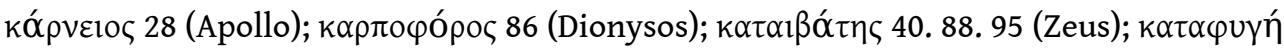

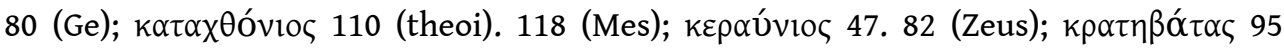

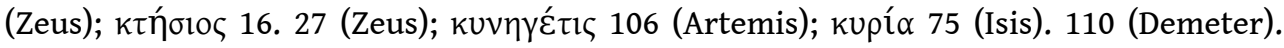
129 (Hygieia); kúploৎ 110 (theoi katachthonioi). 129 (Asklepios); $\mu \varepsilon ́ \gamma \propto \varsigma$ 75 (Sarapis, Zeus

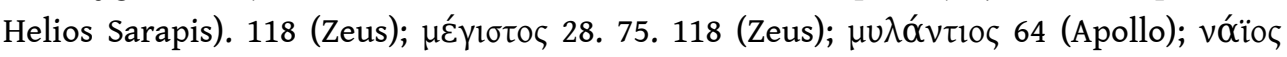

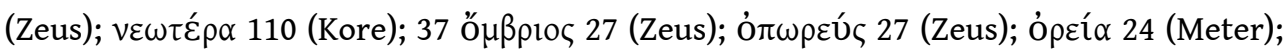

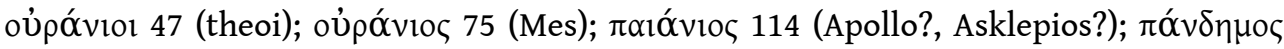

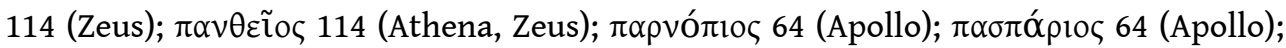

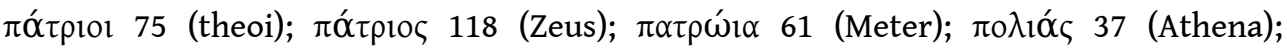

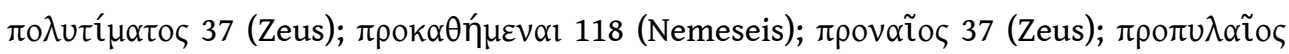

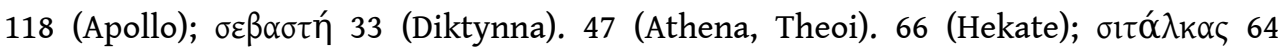

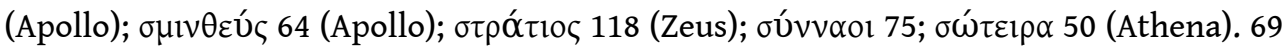

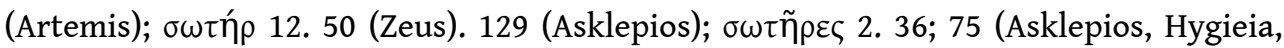

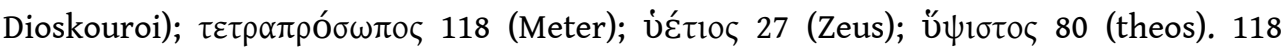

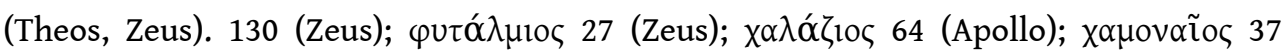

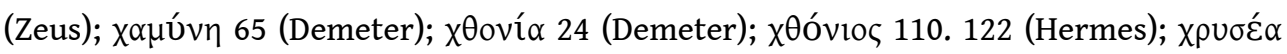
35 (Aphrodite, Artemis, Elpis Kore, Leto, Muse, Nike, Parthenos); ஸ்pírnৎ 64 (Apollo);

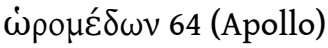

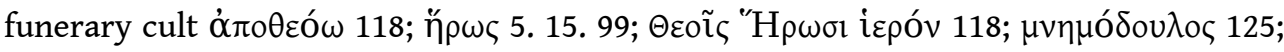

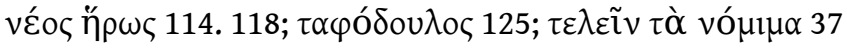

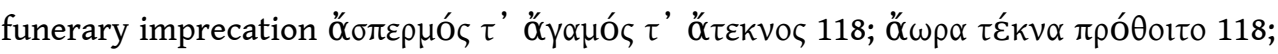

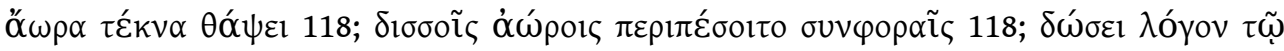

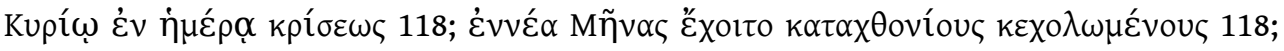

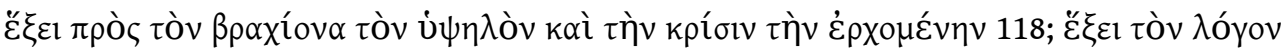

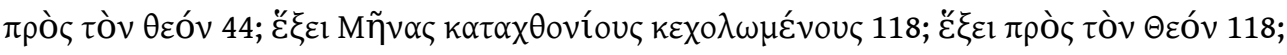

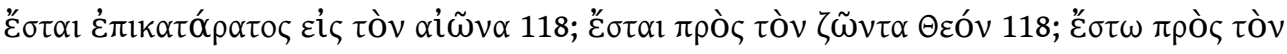

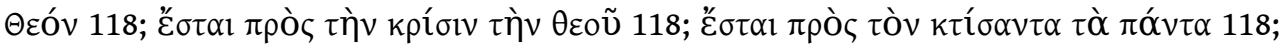

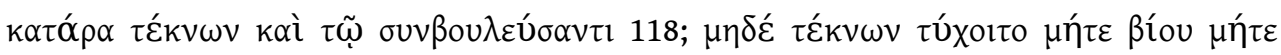

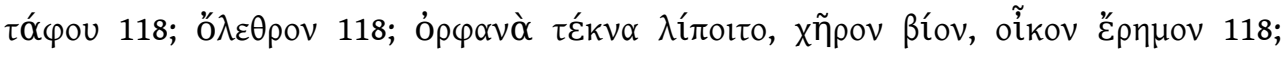

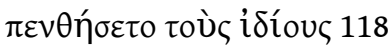

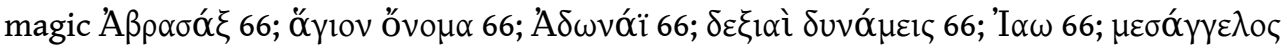

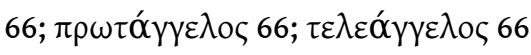

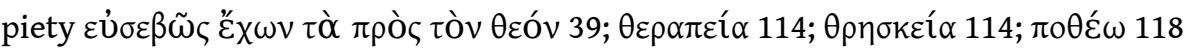

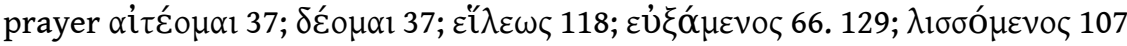

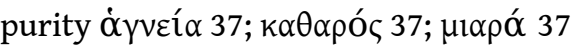

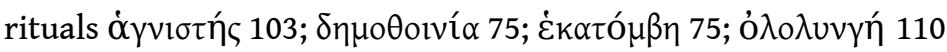

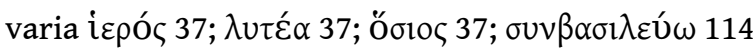

1) M. ABD EL-MAKSOUd, A. ABD EL-FATTAH, M. SeIF EL-Din, "La fouille du Boubasteion d'Alexandrie : présentation préliminaire”, in A. HERMARY, C. DUBOIs (eds.), L'enfant et la mort dans l'Antiquité III. Le matériel associé aux tombes d'enfants, Arles, 2012, p. 427-446: Three early Hellenistic inscribed statuettes were found in the recently excavated 
sanctuary of Boubastis in Alexandria (p. 436-439). They were dedicated to Boubastis by men and women in fulfillment of their vows. The statuette of a cat was dedicated by

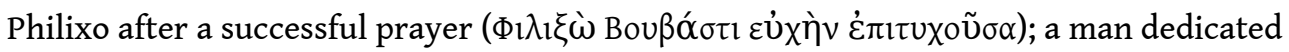

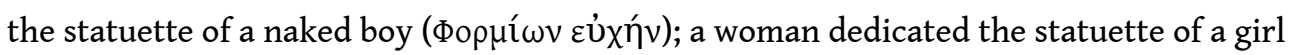

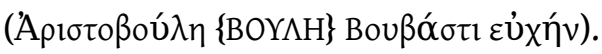

2) Vacat.

3) D. ACKERMANN, "Les prêtrises mixtes : genre, religion et société", in Cities and Priests, p. 7-39: Only a few cults in ancient Greece had priesthoods that were jointly held by a man and a woman. Focusing on the evidence for the cults of the Korybantes in Erythrai (I.Erythrai $206+$ SEG XLVII 1628), Dionysos in Miletos (I.Milet III 1222), Zeus and Hera in Panamara, and Hekate in Lagina (I.Stratonikeia 205, 242, 683), and Atargatis in Delos (SEG LII 761), A. sees multiple reasons for this phenomenon. Cults connected with the initiation of both men and women (e.g. the cult of the Korybantes) required priests of both genders to supervise the purification baths of the initiates. Cult associations consisting of both men and women (e.g. those of Dionysos) had both a priest and a priestess. In Stratonikeia, where the priesthood was occupied by a man and his wife, the joint office was connected with the euergetism of elite families. The role of the family in the cult of Atargatis possibly explains the existence of a mixed priesthood here as well.

166 4) M. ADAK, “Claudia Iasonis, eine Asiarchin aus Lykien”, Hermes 141 (2013), p. 459-475 [BE 2014, 448]: Ed. pr. of an honorific inscription for Claudia Iasonis of Pinara, who served as high priestess of Asia; her brother and father had served as high priests in Lykia (Lydai, early 2nd cent. CE). Iasonis, descendant of a prominent Lykian family, must have been married to a man from Asia.

167 5) M. ADAK, K. STAUNER, "Eine Honoratiorenfamilie aus Nikomedeia", Tekmeria 10 (2013), p. 143-151 [BE 2014, 476]: Ed. pr. of a posthumous honorary inscription for Fl. Ulpius Demokritos, ท̌ $\rho \omega \varsigma$, member of the elite of Nikomedeia; among other services, he held the office of a priest (ca. $200 \mathrm{CE}$ ).

168 6) N.E. AKYÜREK §̧AHIN, “Antalya Müzesi'nden iki Hekataion”, Adalya 14 (2011), p. 237-257 [BE 2012, 53; SEG LXI 1183]: Ed. pr. of a dedication from Antiocheia in Pisidia (2nd/3rd cent.); two pairs of brothers dedicated a statuette of the three-bodied Hekate.

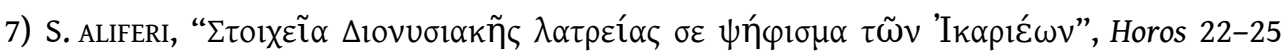
(2010-2013), p. 145-153: A. presents an improved edition of a decree of the Athenian deme of the Ikarieis honoring a demarchos for his services (SEG XXII 117, ca. 350-300). The demarchos had offered the customary sacrifices to all the gods and heroes and

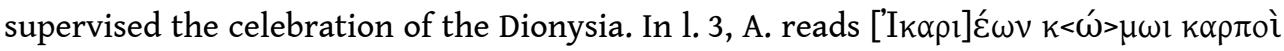

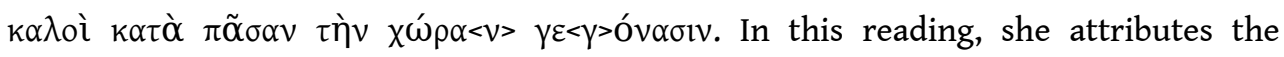
fertility of the land to the performance of the komos.

8) J. ALIQUOT, "Fin de parcours : une épitaphe d'Émèse et le sort de Damascius au retour de Perse", Topoi 18.1 (2013), p. 283-294: A grave epigram from Emesa (IGLS V 2336, 538 CE), which is also preserved in the Greek Anthology (7.553), has been identified as a work of the Neoplatonic philosopher Damaskios. The epigram states that a woman (Zosime?), who during her life was a slave only with regard to her body, found freedom in death ( $\dot{\eta}$

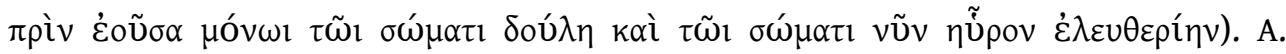
presents a new critical edition and commentary, especially of the very common idea that death means liberation in general and liberation of the soul in particular. Although 
this inscription is generally regarded as evidence that after his exile in the Sassanian court (532 CE) Damaskios did not return to Athens but lived in Emesa, A. points out that one cannot exclude the possibility that the epigram had been composed much earlier, e.g. in Damaskios' youth, and was later copied and used to mark the Emesian woman's grave.

9) W. AMELING, "Ein Altar des Maussollos in Labraunda", ZPE 187 (2013), p. 215-219 [BE 2014, 20 and 434]: An honorary decree for Olympichos (Labraunda, ca. 150-100; SEG LVIII 1220; EBGR 2008, 73) stipulates that a marble altar 'similar to the one for Maussolos in the sanctuary of Zeus Labraundos' should be erected for Olympichos. A. argues that the altar for Maussolos provides evidence for a civic cult of the Karian dynast in Mylasa; it is one of the few examples of ruler cults before Alexander the Great.

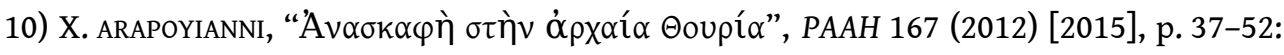
In a report on the excavations in the sanctuary of Asklepios and Hygieia in Thouria [cf. EBGR 2012, 6-8), A. mentions the discovery of a graffito on a Hellenistic vase dedicated to Asklepios ([A $\sigma \kappa] \lambda \alpha \pi \mathrm{r}[--])$.

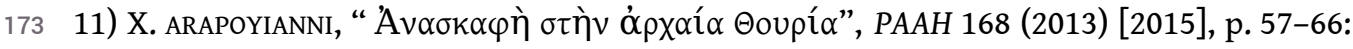
Continuing the reports on the excavations in the sanctuary of Asklepios and Hygieia in Thouria [cf. EBGR 2012, 6-8 and supra $\mathrm{n}^{\circ} 10$ ), A. mentions the discovery of a long cult regulation (49 lines) which concerns the cult of Asklepios and sacrifices offered to Asklepios and other gods in the sanctuary. The text will be published by A. Makri and X. Arapoyianni.

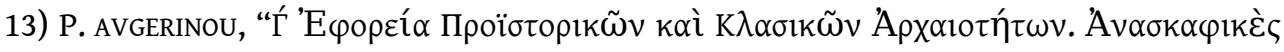

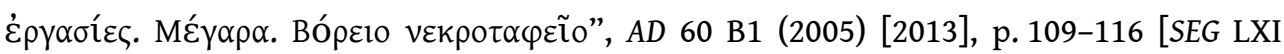
324]: A. reports the discovery of a vase with a graffito (Megara, late 6th cent.). The vase was dedicated to Hermes (i $\alpha \rho o ̀ c: ~ h \varepsilon \rho \mu \tilde{\alpha}: \dot{\varepsilon} \mu \mathrm{l}$ ).

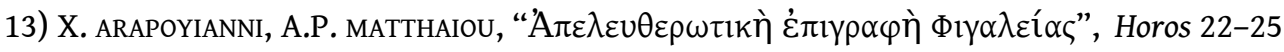
(2010-2013), p. 289-307: Ed. pr. of a bronze tablet inscribed with a manumission record, found in the sanctuary of Athena and Zeus Soter in Phigaleia (ca. 460-450). The text mentions a fine payable to Athena by any violator of the manumission. The text

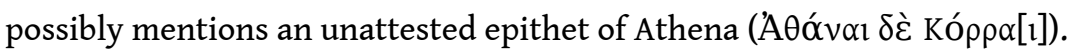

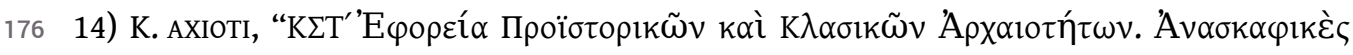

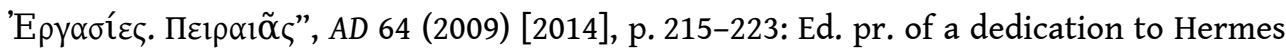
$(\Delta \eta \mu \eta ́ \tau \rho ı \varsigma ~ ' E \rho \mu \varepsilon \tilde{) ~ f o u n d ~ i n ~ a ~ l a t e ~ C l a s s i c a l / e a r l y ~ H e l l e n i s t i c ~ h o u s e ~ i n ~ P i r a e u s . ~}$

15) J.-S. BALZAT, B.W. MILlIS, "M. Antonius Aristocrates. Provincial Involvement with Roman Power in the Late 1st Century B.C.", Hesperia 82 (2013), p. 651-672: Ed. pr. of a Latin honorific inscription for Marcus Antonius Aristokrates, agonothetes of the Isthmia and Kaisareia, set up by the tribe Iulia (Corinth); the general assumption is that the Kaisareia began in $30 \mathrm{BCE}$; this may be the earliest attestation for the return of the control of the Isthmia to Corinth. As Aristokrates was a friend and supporter of Mark Antony (Plut. Ant. 69.1), his agonothesia suggests that he must have reconciled himself with Octavian. He was honored in Athens (IG II ${ }^{2}$ 3889) and in Argos. In Argos, an

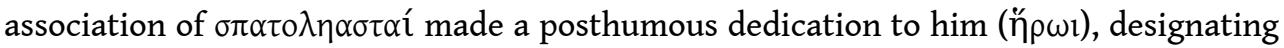
him as ktistes (IG IV 581); a gymnasiarchos donated a statue of Aristokrates to this association (SEG LIII 293). 
178 16) F. BATtistoni, P. ROTtenhÖFER, "Inschriften aus dem Raum Keles und Orhaneli (Provinz Bursa, Türkei)”, EA 46 (2013), p. 101-165 [BE 2014, 398, 475]: B.-R. present inscriptions from Olympene and Abrettene (Bithynia), both new texts and revised editions of published texts; new texts are marked with an asterisk; all texts date to the Imperial period. In the introductory section of their article (p. 105-108), they give an overview of cults and rituals in this area. They discuss the dating with reference to a prophetes (cf. I.Hadrianoi 6, 12, 19, 23-26, 29, 30, 32-34; MAMA IX 60; SEG LVIII 1451; new inscriptions $\left.\mathrm{n}^{\text {os }} 18,19,21^{*}, 22^{*}, 48\right)$ [see also infra $\mathrm{n}^{\circ} 83$ ], the existence of an oracular site in the sanctuary of Zeus Kersoullos at Tazlaktepe (cf. I.Hadrianoi 24), and the existence of a sanctuary (of Asklepios and Hygieia?) at Barakli (cf. I.Hadrianoi 16). We

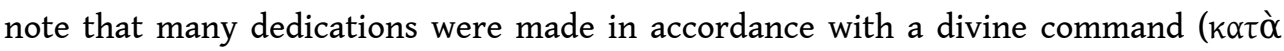

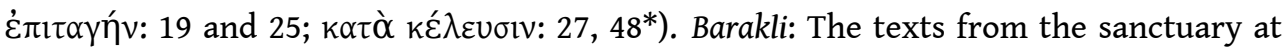

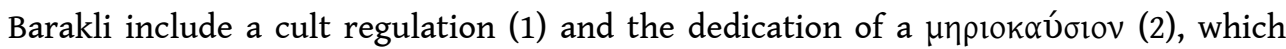
have already been presented in EBGR 2012, 55; in another fragmentary text (3, ca. 2nd

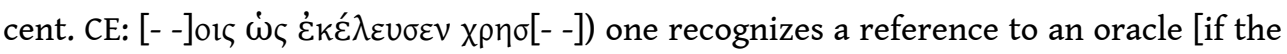

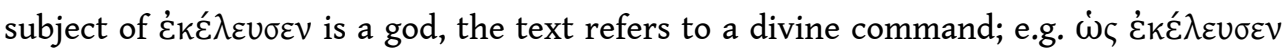
$\chi \rho \eta \sigma[\mu \tilde{\omega}])$. Keles: A man and his wife dedicated an altar to Zeus Ktesios in their house (6,

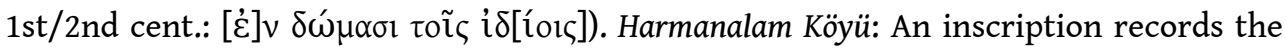
dedication of an altar $\left(10^{*}\right)$. Dedeler: The statue of a snake was dedicated to an anonymous deity $\left(11^{*}\right)$. A mason dedicated a $\beta \alpha ́$ ópov to an anonymous god (12). Akçapinar: Dedications to Apollo (16=I.Hadrianoi 13) and Zeus Kersoullos (17= I.Hadrianoi 3). Belenören: Dedications to Zeus Kersoullos $\left(18^{*}-27^{*} ; \mathrm{n}^{\text {os }} 18-19\right.$ are votive columns). Haydar: A column was dedicated to Zeus Kersoullos for the victory of

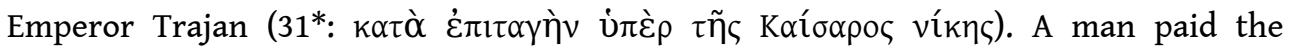
expenses for the construction of a pavement in the sanctuary of Zeus Kersoullos (32*); another dedication, probably to the same god, was made on behalf of two individuals (33*). Menteşe: An epitaph mentions the offices of a man who served, among other things, as panegyriarches and agonothetes, and of a relative who became priest $\left(35^{*}, 2 \mathrm{nd} /\right.$ 3rd cent.). For a dedication from Orhaneli that mentions a prophetes (36), see infra $\mathrm{n}^{\circ} 83$.

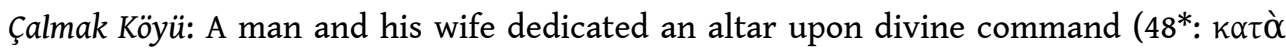

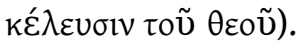

179 17) V. BELELLI, "Un'iscrizione greca dipinta e i culti della Vigna Parrocchiale a Caere", Studi Etruschi 74 (2011), p. 91-124 [BE 2012, 81]: Ed. pr. of a cup from Caere (early 5th cent.), inscribed after firing with the letters $\Delta \mathrm{IO}$, probably the abbreviated name of Dionysos. The use of the Greek language confirms Livy's report that the cult of Dionysos was introduced in Etruria by Greeks of Magna Graecia.

18) A.V. BELOUSOV, 'Olbian Inscription IOSPE I 2140 Revisited”, VDI (2013), p. 158-163: A dedication to Achilleus Pontarches from Olbia (IOSPE $\mathrm{I}^{2} 140$, Imperial period) was made

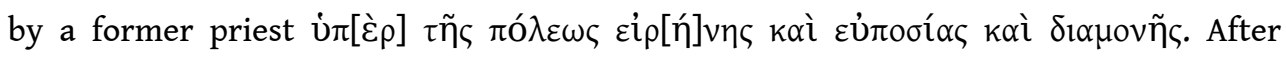
surveying the use of the expression $\dot{v} \pi \dot{\varepsilon} \rho \delta 1 \alpha \mu$ ov $\tilde{\eta}_{\varsigma}$ in Greek dedications, mostly on

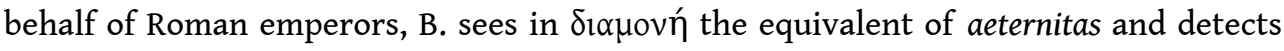
Roman influence in the Olbian text.

19) F. BERTI, "Iasos, 2009, Campaign", KST 32.1 (2011), p. 176-187: Two fragments of a long Hellenistic regulation concerning the sale of the priesthood of Meter Theon were found in Iasos (p.182). The text is still unpublished, but B. gives a summary of its content. The woman, who purchased the priesthood, was to serve as priestess for life for both Meter Theon and Mater Phrygia. She would be responsible for a sacrifice and a 
procession that started at the prytaneion. She received parts of the victims from public and private sacrifices (p. 182).

20) G. BeVilacqua, O. Colacicchi, M.R. GiUliani, "Tracce di ousia in una defixio dalla Via Ostiense: un lavoro multidisciplinare”, in M. PIRANOMONTE, F. MARCo SIMÓN (eds.), Contesti Magici - Contextos Magicos, Rome, 2012, p. 229-236: Two lead curse tablets were found in 2003 close to the catacombs of St. Domitilla in Rome (1st/2nd cent.). One of the tablets had been folded four times and pierced with a nail; laboratory analysis revealed the presence of a piece of textile in the folded tablet. This corresponds to a practice mentioned in magical papyri, that is, the use of organic material (ov่oí $\alpha$ ) belonging to the victim of the curse. B. lists 11 related defixiones, either found together with material remains ( 9 cases) or referring to the hair of women cursed by the defigens (p. 236). [The Greek text has now been published by G. BEVILACQUA, "Athletai e palaistai in una defixio greca di Roma", ZPE 188 (2014), p. 215-229; it is a curse against athletes.]

21) G. BEVILACQUA, R. D'ORIANo, "Exotica come segni del potere. Un thymiaterion cnidio di Olbia", in M. BASTIANA Cocco, A. GAVINI, A. IBBA (eds.), L'Africa Romana XIX. Transformazione dei paessaggi del potere nell'Africa settentrionale fino alla fine del mondo antico. Atti del XIX convegno di studio Sassari, 16-19 dicembre 2010, Rome, 2012, II, p. 1943-1958: Ed. pr. of an incense burner from Olbia in Sardinia (1st cent. CE) with the inscription $[\Theta \varepsilon]$ oĩ $ৎ \lambda \alpha \beta \varepsilon$. This object belongs to a group of incense burners and lamps produced in Knidos. The

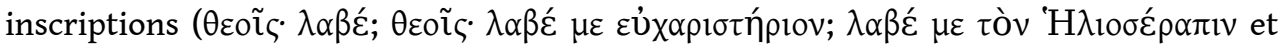
sim.) show that they were used as votive offerings. The example from Olbia was possibly owned by an imperial freedman as a luxury object.

22) S. BÖNISCH, A. LEPKE, "Neue Inschriften aus Patara II. Kaiserzeitliche Ehren- und Grabinschriften", Chiron 43 (2013), p. 487-525: Ed. pr. of honorific inscriptions for a priest of the civic imperial cult (1) and a highpriest of the provincial emperor cult in Lykia (2-3, Patara, 2nd cent. CE).

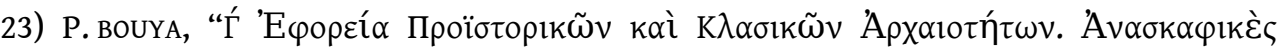

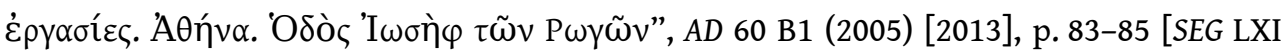
70]: In a report on salvage excavations conducted in the area of the sanctuary of Apollo Pythios in Athens [cf. EBGR 2012, 122], B. mentions two choregic dedications of the 5th and 4th cent., made after victories at the Thargelia of choruses of the tribes Kekropis (chorus of paides) and Akamantis.

186 24) J.N. BREMMER, "Divinities in the Orphic Gold Leaves: Euklês, Eubouleus, Brimo, Kybele, Kore, and Persephone", ZPE 187 (2013), p.35-48: B. surveys the several divinities that appear in the Dionysiac-Orphic texts, traces their origin in various cults, and comments on connections and associations between them (references are to the Orphicorum Fragmenta). Eukles and Eubouleus appear among the gods to whom the deceased assures that he/she comes 'pure from the pure' (OF 488-491). These names may have been selected because they contributed to the solemn atmosphere and because of their reassuring character (being composites of $\varepsilon \tilde{u}$ ). Eukles, identified by Hesychios (s.v.) as a name of Hades, can be identified with the Samnite god Evklus. In the 'Tavola di Agnone', Evklus appears together with Ceres and the 'daughter of Ceres'; the three gods correspond to the Eleusinian triad. The name Eukles is related to Klymenos, a designation of Hades (Paus. 2.35.9). In Hermione, Klymenos appears together with Demeter and Kore both in literary texts (Poetae Melici Graeci 702 fr. 1 ed. Privitera; cf. Kallimachos, fr. 285 ed. Pfeiffer) and inscriptions (IG IV 686-691, 715, 
1609). Eubouleus, an epithet of Zeus, is primarily found in the Cyclades, where he was worshipped together with Demeter, and sometimes also with the Kore and Baubo (IG XII.7 76-77; XII.5.227, 677; XII Suppl. 196; cf. Zeus Bouleus: SEG XI 188; Syll. ${ }^{3}$ 1024). The cult of Zeus Eubouleus, Demeter, and Kore was associated with the Thesmophoria. B. identifies Eubouleus with Eubolos, who in Athens appears together with Theos (Hades) and Thea (Persephone; IG $\mathrm{I}^{3}$ 78). B. suggests that "Baubo and Eubouleus were first "imported" from the Cyclades into the Attic Orphic poem of that period [ca. 450-425], from which Eubouleus was subsequently imported into Eleusis'. Brimo is attested in the Eleusinian mysteries and in a Dionysiac-Orphic leaf from Pherai (OF 403). A leaf from Thourioi (OF 492) mentions Protogonos, Ge, Meter, Kybele, Kora, and Demeter; the connection of Demeter and Meter is now also attested in a leaf from Pherai, which mentions Demeter Chthonia and Meter Oreia (SEG LV 612; EBGR 2005, 117). As regards Persephone, B. adopts R. Wachter's interpretation of her name ('the one who beats the

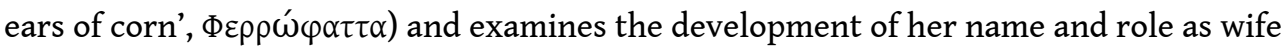
of Hades and queen of the underworld. She is not often mentioned in the Orphic tablets

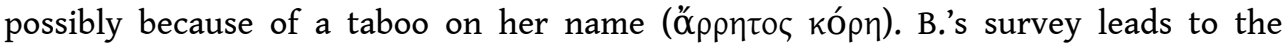
conclusion that the Orphics took their divinities mainly from rituals associated with Demeter and Kore.

25) J.N. BREMMER, "Local Mythography: The Pride of Halicarnassus", in S.M. TRZASKOMA, R.S. SMITH (eds.), Writing Myth: Mythography in the Ancient World, Leuven et al., 2013, p. 5573: B. discusses the evidence provided by the so-called 'Pride of Halikarnassos', a long hexametrical poem referring to local myths and glorifying the city (SEG XLVIII 1330), for the study of local mythography. 1) Zeus and the Kouretes (1. 5-14): The poem refers to Zeus' birth and the ancestors of his prospoloi, i.e., the leading citizens 'who were Zeus' priests, banqueted and performed mystic rites'. These 'earth-born' ancestors, connected with local autochthony myths, can be identified with the Kouretes, the first inhabitants of Halikarnassos. 2) Salmakis and Hermaphroditos (1.15-22): The poem refers to the nymph Salmakis, who civilized wild people and reared Hermaphroditos, the inventor of marriage. Drawing on literary traditions, B. suggests that there was a tradition about the effeminising effect of the spring of Salmakis; according to a reinterpretation of this tradition, the local Karians and Leleges were civilized by drinking this water. 3) Greek colonizers (Bellerophontes, Kranaos, Endymion, Antheas; 1. 24-32): Through references to founding heroes, the poet established the city's connection with Karia, Athens, and Troizen, and linked the prominent family of the Antheadai with the city's foundation. The 'Pride of Halikarnassos' is a rare example of Hellenistic mythography, showing how this genre served local prestige and cultural capital.

26) F. BRIQUEL-CHATONNET, "Les inscriptions phénico-grecques et le bilinguisme des Phéniciens", CRAI (2012), p.619-638: In a study of bilingual Greek-Phoenician inscriptions, B.-C. adduces several texts of religious interest: the dedication to Aphrodite by King Abdalonymos of Sidon (Kos, IG XII.4.546), a dedication to Herakles Archegetes (Melquart) from Malta (CIS I 122), and a dedication to Hermes and Herakles by a hieropoios and gymnasiarchos from Arados (IGLS VII 4000).

27) P. BRULÉ, "Maître du ganos, le Zeus de Palaikastro est un Zeus comme les autres”, in Hymnes, p. 253-267: The 'Hymn of the Kouretes' from Palaikastro (4th/3rd cent.; I.Cret. III.ii.2; FURLEY/BREMER, Greek Hymns 1.1) characterizes Zeus with the expression

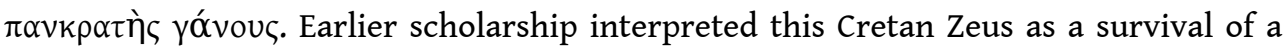
Minoan god or a patron of initiatory rituals of young men. B. examines in detail the 
various meanings of үóvoৎ and its association with water, brilliance, joy, and fertility, arguing that the perception of Zeus in this hymn does not differ from the general, 'panhellenic', perception of this god. Zeus was often regarded as patron of fertility and

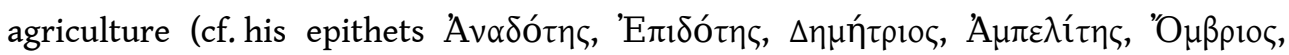

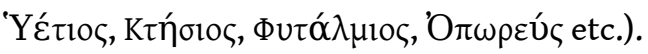

28) C. BRUNS-ÖZGAN et alii, Knidos. Ergebnisse der Ausgrabungen von 1996-2006, Istanbul, 2013 [BE 2014, 21 and 38]: The report on the results of the excavations conducted in Knidos includes several inscriptions, some of which are of religious interest: a dedication to Apollo Karneios and Hadrian (p. 147-152); dedication of statues to Zeus Megistos made by Theandros after he had been honored by the people (p. $152 \mathrm{f}$;; Hellenistic); a dedication of a statue of the Rhodian people to the gods (p. 171-173; Hellenistic).

29) F. CAMIA, “A Note on the Athenian Hiereus of Drusus Hypatos", Tekmeria 11 (2012),

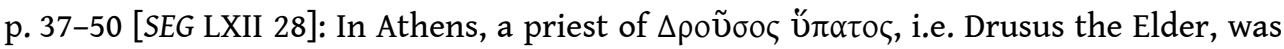
appointed annually. This priesthood, created in the year of Drusus' death or shortly thereafter ( $9 / 8 \mathrm{BCE}$; see IG $\mathrm{II}^{2} 1722$ ), was regularly held by the eponymous archon. The cult of Drusus remained distinct after a reform of the imperial cult in the mid-1st cent. CE, when the latter was consolidated to address all the Sebastoi together, and is attested until the early 2 nd cent. CE. The survival of the separate cult is attributed by C. to the fact that the priesthood was connected with the office of the eponymous archon. C. suggests that the priesthood was abolished when Hadrian first visited Athens as a privatus in 111/112 CE. In a table, C. collects the epigraphic evidence for the priesthood of Drusus.

30) J.-M. CARBON, "Dolphin Pillars", EA 46 (2013), p. 27-34 [BE 2014, 433]: The starting point of C.'s study is an altar from Mylasa, dedicated to an anonymous god by Eutychos and the association of the temenitai, and decorated with a relief representation of a dolphin on a pole or pillar (SEG LIV 1107, 2nd/1st cent.) [EBGR 2004, 26]. C. plausibly identifies the recipient of the dedication as Apollo Delphinios and collects evidence for cult associations with the name $\tau \varepsilon \mu \varepsilon v i \tilde{\tau} \alpha$ or $\tau \varepsilon \mu \varepsilon v i ́ \zeta o v \tau \varepsilon \varsigma$, the cult of $\dot{\varepsilon} v \tau \varepsilon \mu \varepsilon v_{v 10} \theta \varepsilon o$, and dolphin pillars. He tentatively suggests that the $\gamma \cup \lambda \lambda \lambda_{o}$, boundary markers at the gates of Miletos and Didyma that were crowned during the procession of the molpoi in Miletos (I.Milet VI.1.133), supported effigies of dolphins. In an appendix, C. restores the name of the aisymnetes who made a dedication to Apollo Delphinios and the $\theta \varepsilon o$ i $\dot{\varepsilon} \nu \tau \varepsilon \mu \varepsilon ́ v 10$ in Miletos (I.Milet I.3.159): Leon, son of Indos, who served as aisymnetes in 323/2 BCE.

193 31) J.-M. CARBon, V. PirenNe-Delforge, "Priests and Cult Personnel in Three Hellenistic Families", in Cities and Priests, p. 65-119 [BE 2014, 132, 444]: The authors offer a detailed comparative analysis of the role of priests in three Hellenistic private cult foundations: the foundation of Diomedon in Kos (IG XII.4.348= LSCG 177), of Poseidonios in Halikarnassos (LSAM 72; new critical edition, translation, and commentary by J.M. Carbon on p. 99-114), and of Epikteta in Thera (IG XII.3.330 = LSCG 135). The three inscriptions contain dossiers of documents that were written at different times, reflecting the need for revisions. The authors discuss the content of these inscriptions, the duties and perquisites of the priests and other personnel serving in the family cults, and the constellations of divinities worshipped by these family groups. Although the documents make no reference to the polis, the priesthoods and the arrangements for other cult personnel mirror the forms of public priesthoods. Given the emphasis on family commemoration in all three foundations, it is clear that the priests were 
appointed from within kinship groups according to a principle of male primogeniture. Special arrangements were made for the selection and appointment of epimenioi, who assisted in the cult service. The statutes of these foundations mention different rules concerning inclusivity - allowing for the acceptance of illegitimate children (Diomedon), and women (Poseidonios and Epikteta).

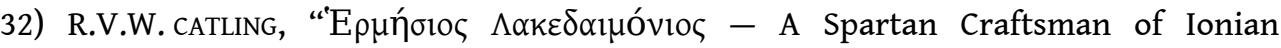
Origin?", in N. SEKUNDA (ed.), Ergasteria: Works Presented to John Ellis Jones on his 80th Birthday, Gdansk, 2010, p. 44-55 [SEG LX 315; BE 2011, 279]: C. studies an inscribed bronze disk from Olympia (ca.550-500, SEG LVII 398), identifying the dedicants as

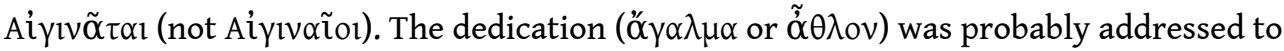
Zeus Olympios. The craftsman, Hermesios 'the Lacedaemonian', was an Ionian immigrant.

195 33) A. CHANiotis, "Hadrian, Diktynna, the Cretan Koinon, and the Roads of Crete. A New Milestone from Faneromeni (Crete)", in W. ECK, B. FEHÉR, P. KovÁc (eds.), Studia Epigraphica in memoriam Géza Alföldy, Bonn, 2013, p. 59-68: Ed. pr. of a milestone from Faneromeni (in the area of Phaistos). According to the text, Hadrian ordered the construction of a road using sacred money (pecunia sacra) of Diktynna. The milestone possibly marked a newly constructed or repaired road from Matalon to Gortyn. The use of Diktynna's money for the construction of roads in Crete under Hadrian was already

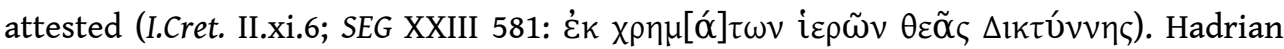
could order the use of this sacred money because Diktynna's sanctuary was not controlled by a single city but was under the jurisdiction of the Cretan Koinon. The coins issued by the Koinon were decorated with images of Diktynna, the newborn Zeus,

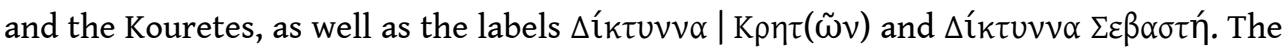
epithet Sebaste (Augusta) suggests a close relationship between the goddess and the imperial cult. An inscription from Lyttos (I.Cret. I.xviii.44) refers to a similar

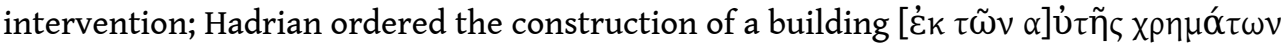
(Diktynna's money?).

196 34) T. CORSTEN, O. HÜLDEN, J. GEBAUER, "Forschungen in der Kibyratis im Jahre 2009", AST 28.1, p. 67-81 [SEG LXI 1234-1235]: C. mentions inscriptions found during a survey in Kibyra and its territory: 1) The epitaph of Nana, priestess of Aphrodite [now published by T. CORSTEN and O. HÜLDEN, "Zwischen den Kulturen. Feldforschungen in der Kibyratis. Bericht zu den Kampagnen 2008-2011”, MDAI(I) 62 (2012), p. 38-40]. 2) A former tenant of the village (?) of Tangara dedicated a temple to Zeus Epekoos (206 CE) [see now T. CORSTEN, "An Inscription from Çavdir in the Burur Museum and the Persistence of Ancient Place Names”, in H. METIN et alii (eds.), Pisidian Essays in Honour of Hacı Ali Ekinci, Istanbul, 2015, p. 7-11].

197 35) T. CoRsten, M. RICL, "A Dedication to Herakles, Hosios and Dikaios, and Chrysea Parthenos from the Kibyratis", Gephyra 9 (2012), p. 143-151: Ed. pr. of an important dedication from Byramlar, near Kibyra (ca. $200 \mathrm{CE}$ ). The text was first copied by J. and L. Robert in 1948 and rediscovered by C. in 1997 and 2008. Three priests, one of which is also designated as neokoros, constructed and dedicated a temple to the gods who listen

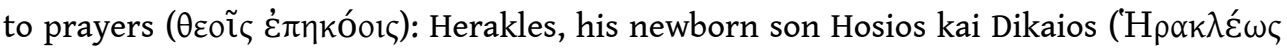

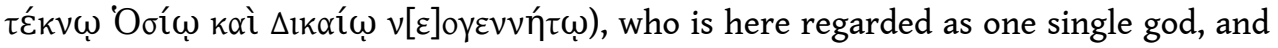

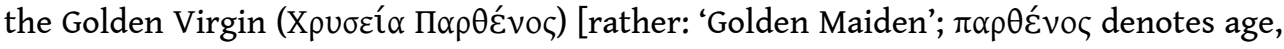
not (primarily) virginity]. Herakles is probably to be identified with the local god Kakasbos. Pictorial representations associate him with Hosios and Dikaios, but this is 
the first reference to the belief that he was the father. Herakles may have been associated with Hosios and Dikaios as patron of justice. 'Golden' is often used as an attribute of various gods (Aphrodite, Artemis, Elpis, Kore, Leto, Muse, Nike and Zeus). Nothing is known about the goddess called 'Golden Maiden'; she seems to have formed a divine triad together with Herakles and his son.

36) A. CoşKUn ABuAGLA, "The Cult of Meter Theon in Pisidian Conana", Gephyra 10 (2013), p. 132-134: Ed. pr. of two dedications from Konana. The first text mentions that Attalos,

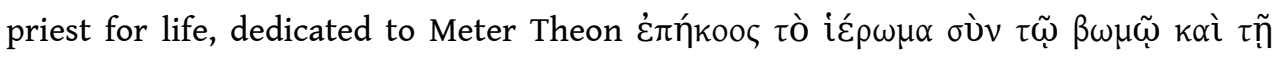

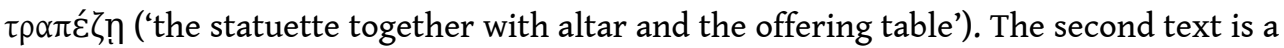
fragmentary dedication to the Theoi Soteres by a priest (2nd/3rd cent. CE).

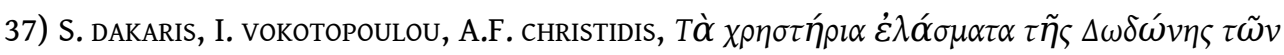
$\dot{\alpha} v \alpha \sigma \kappa \alpha \varphi \tilde{\omega} v \Delta$. Ėं $\alpha \gamma \gamma \varepsilon \lambda i ́ \delta \eta$, Athens, 2013: 4216 oracular tablets found in Dodona in 19281932 and 1952-1959 are presented in this long-awaited publication. Its history, which began in 1981 with the agreement of the three authors to publish the tablets, is narrated by V.C. Petrakos in the preface; the book was expected to be ready in 1995, but work was delayed because of the deaths of Vokotopoulou and Dakaris in 1995 and 1996 respectively. Christidis completed the difficult work of reading the tablets only days before his death in 2004. The readings and comments of the authors, as well as additional comments that were contributed by several other scholars, were finally prepared for publication by S. TSELIKAS. Some will be quick to criticize a few weaknesses of the final product, such as the absence of photos (only drawings are presented), some unsatisfactory readings and interpretations, and obvious problems in the dating of the majority of the tablets. But gratitude, not quibbling, is the proper response to this truly monumental work that will allow scholars in the future to gain a better understanding of the oracular practices at Dodona. The two volumes do not contain tablets that were found after 1959 (ca. 100 tablets in Berlin), nor do they include very small fragments with only individual letters or illegible texts. The editors have not attempted to organize this material according to any thematic criterion; the tablets are presented by their inventory number in the Museum of Ioannina. But the elaborate index, compiled by G. PAPADOPOULOS, will allow the users of the volume to find most any information they are seeking. It is impossible to present the inscriptions in detail here, but the recent book by É. LHôTE, Les lamelles oraculaires de Dodona, Geneva, 2006 (EBGR 2007, 82), provides a very good overview of the content and the reasons for which individuals and in a few cases also cities and koina - turned to the oracle. They were concerned with their general well-being and that of family members, marriage, offspring, residence, manumission, citizenship, health, financial affairs, especially agriculture and maritime trade, the finding of treasure, agonistic matters, theft, murder, lawsuits, military matters, migration, religion and magic. Whenever an inquiry is connected with a particular problem for the first time, the volume provides a list of parallels; e.g., one finds references to inquiries about marriage under $n^{\circ} 1$ : marriage, trade under $n^{\circ} 3$, and so on (4: questions addressed by women; $5 \mathrm{~A}$ : offspring; 11B: residence and migration; 8B: animal husbandry; 20A: multiple inquirers; 35A: mercenary service; 97A healing; 103A: disease, etc.). Through the publication of this material, some new themes emerged that were not well represented in the limited texts previously known: the great importance of hero cults $(45 \mathrm{~B}, 90,359 \mathrm{~B}, 481,487 \mathrm{~A}, 520,542 \mathrm{~A}, 558 \mathrm{~B}, 565 \mathrm{~A}, 573 \mathrm{~A}$, 574A, 848, 914B, 998B, 1031B, 1087B, 1201A, 1287B, 1370A, 1455A, 1508A, 1585A, 1781B, 1864A, 2036B, 2050A, 2100B, 2107A, 2209B, 2242A, 2282A, 2287A, 2356A, 2359A, 2362B, 
2432B, 2453A, 2668A, 3053A, 3084A, 3309A, 3424A, 3458A, 3481, 3497A, 3539A, 3558A, $3625 \mathrm{~A}, 3696 \mathrm{~B}, 3756 \mathrm{~A}, 3778 \mathrm{~A}, 3792 \mathrm{~A}, 3816 \mathrm{~B}, 3828 \mathrm{~A}, 3868 \mathrm{~A}, 4004 \mathrm{~A}, 4214 \mathrm{~A})$ and the frequency of questions concerning health and crime (see below). Based on the new texts, further progress can also be made as regards the methods of divination. It will take many years and the efforts of many scholars to fully exploit this material for the study of Greek religion, society, and law (see already the remarks of É. LHOTE, BE 2014, 255). Many aspects of the tablets were discussed in the conference 'Dodona. New approaches to the oracular tablets' in Athens (September 16, 2016).

In the following very selective presentation, new texts that are discussed in some detail are marked with an asterisk. If not otherwise stated, the inscriptions roughly date to the Classical period, but the dates given in this corpus are only approximate. Many texts belong to the 3rd and early 2 nd cent., and not the 4 th cent., as dated by the eds. The earliest readable text dates to the late 6 th cent. $\left(968 \mathrm{~A}^{*}\right)$, the latest texts are from the first half of the 2 nd cent. [It should be noted that not all the texts written on lead tablets and included in these two volumes are oracular tablets. The tablets were also used for inscribing abecedaries - probably as writing exercises - and tablets with personal names or numerals may have served other purposes. I should also remark that some of the texts are not formulated as questions but as requests. In $n^{\circ} 2510^{*} \alpha i \tau \varepsilon \tilde{\tau} \tau \alpha l$ is

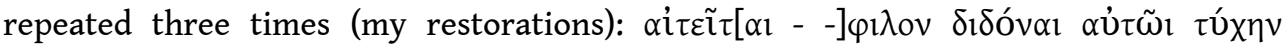

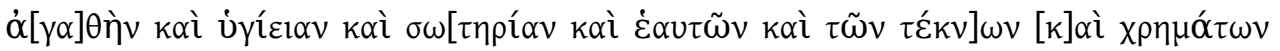

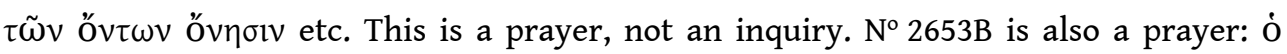

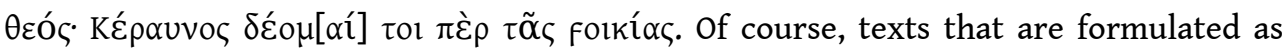
questions also seek, ultimately, to attract the god's attention to a person's worries. $\mathrm{N}^{\circ}$

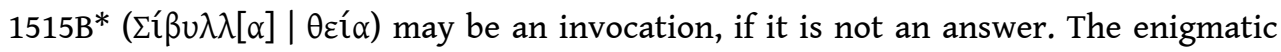

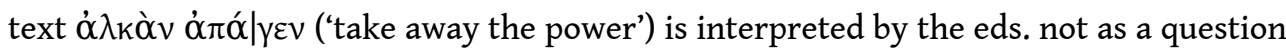
but as a request, analogous to magical prayers beseeching that an opponent should lose his power $\left.\left(849 A^{*}\right)\right]$.

Divinatory practices: The questions are usually directed to Zeus Naios and Dione; Zeus is

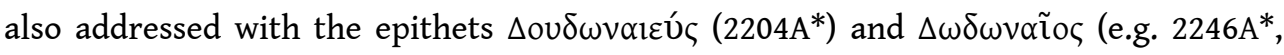
$\left.2261 A^{*}\right)$. Other gods that are subject to inquiries in the tablets are Hestia $\left(2171 \mathrm{~B}^{*}\right)$, Tyche $\left(80 \mathrm{a}^{*}\right)$, and Themis $\left(128 \mathrm{~A}^{*}, 3055 \mathrm{~A}^{*}\right)$. Porinos of Kyme, planning to serve a Persian satrap as mercenary $\left(35 \mathrm{~A}^{*}\right)$ [dated by the eds. to ca.350-300 but probably much earlier], addresses his question not to Zeus Naios but to Zeus Pronaios, probably

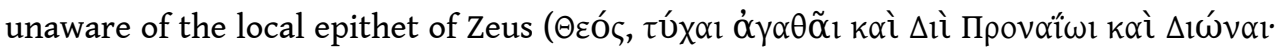

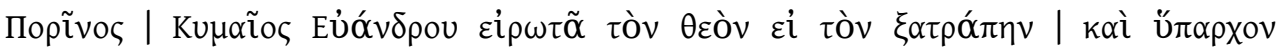

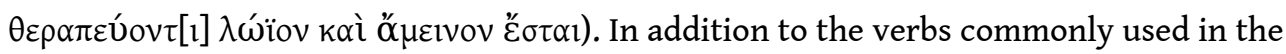

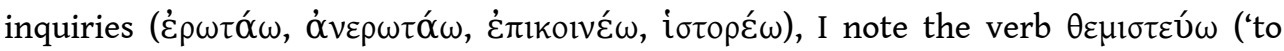
answer': 128A, 572B, 1394). Some of the tablets clearly report the response of the gods [as R. PARKER ('The Lot Oracle at Dodona”, ZPE 194, 2015, p. 111-114) has plausibly argued, one of the methods of divination practiced in Dodona was cleromancy; two alternative answers were prepared and one was drawn by lot; the tablets must, therefore, contain numerous possible answers]. The eds. provide a list of answers under $\mathrm{n}^{\circ} 42 \mathrm{~B}$ : 70A, 93B, 108B, 154B+155B, 170A, 200, 519B, 657A, 1045A, 1077B, 1154A, 1299B,

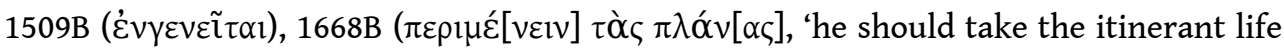

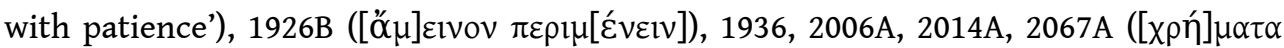

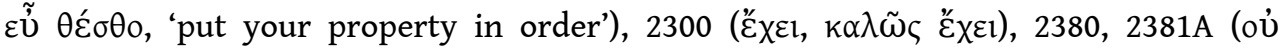

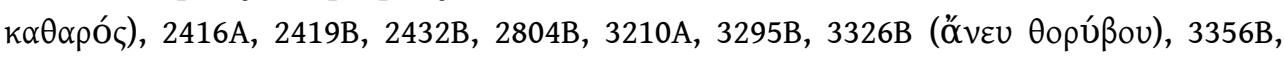


$3626 \mathrm{~B}, 3809 \mathrm{~B}, 4080 \mathrm{~B}, 4215 \mathrm{~B}$. A clear case of question-answer pair is a tablet with writing

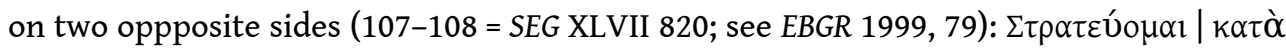

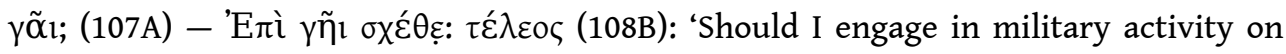

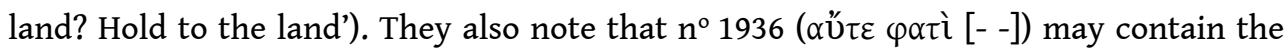
utterance of a prophetess. Another clear example of an answer is $\mathrm{n}^{\circ} 70 \mathrm{~A}^{*}$, which also

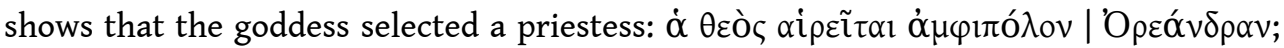

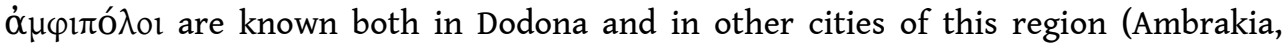
Apollonia). [Since the goddess is not named, it must be Dione, and the priestess must be of Dodona. Unfortunately, the eds. in many cases have arbitrarily restored interrogative words in fragmentary tablets, thus turning answers into questions, or have interpreted short texts as labels, though they may well be answers: e.g. MENE

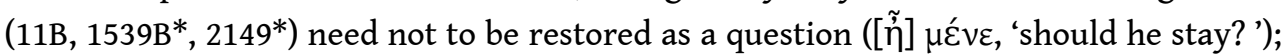

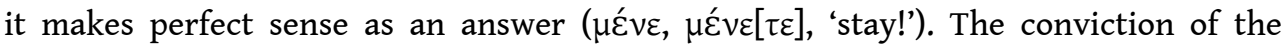
editors that the tablets rarely contain answers is so strong that in the case of $519 \mathrm{~B}^{*}$,

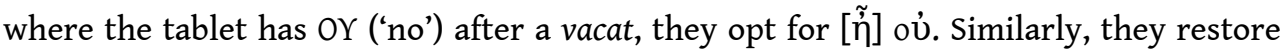

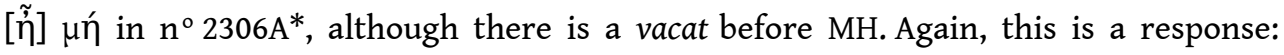
'don't!' Similarly, the eds. regard oủk a'ț[10ৎ] (1593B*) as a question despite the lack of an interrogative word. Here, I cannot present a full list of potential responses, but a few examples suffice to show the need to revisit the tablets. $\mathrm{N}^{\circ} 82 \mathrm{~A}^{*}$ seems to be an answer:

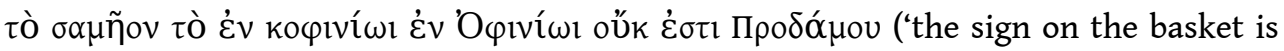
not that of Prodamos' or 'the marker in Ophinion does not belong to Prodamos'). Some

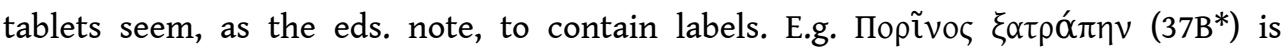
probably a label for the question of Porinos: 'will it be better for me to serve the satrap and hyparchos?' $\left(35 \mathrm{~A}^{*}\right)$. But things are less clear in many other short texts interpreted by the eds. as labels: e.g. the eds. understood غ่v Kpótovı ('in Kroton', 26B) as a label, because it was written by the same hand that also engraved an inquiry about migration

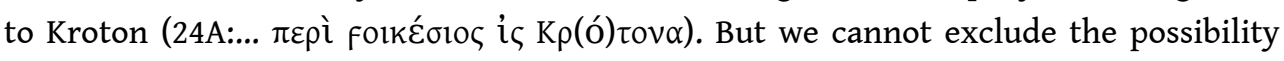
that it is a response ('in Kroton'). If cleromancy was practiced, $\dot{\varepsilon} v$ Kpótovı may well be one of the two potential responses, $\mu \varepsilon ́ v \varepsilon$ being the other ('[it will be better] in Kroton'

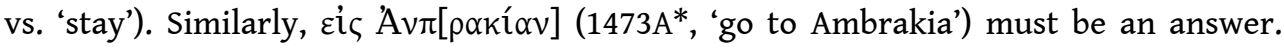
Furthermore, tablets containing the text $\tilde{\eta} \mu$,' 'or not?' (e.g. 100B, 2346B, 2443A, 2689A, $2816 \mathrm{~B}, 2974 \mathrm{~A}$ ) may well be the negative alternatives to a question. $\Delta \omega \rho \mathrm{s}$. (173B) is too vague to be a meaningful label, whereas it makes perfect sense as response to the question 'To Zeus Naios and Diona; should they not use Dorios, the necromancer?' ([- -

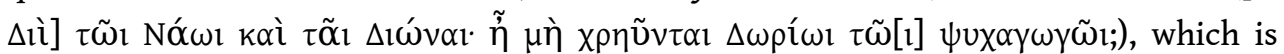
written on the interior of the same tablet (172A). $\mathrm{N}^{\circ} 2054 \mathrm{~B}^{*}$ asks whether a trade

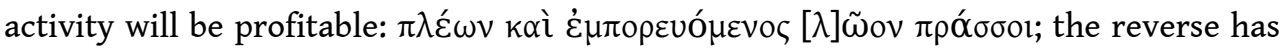
the abbreviation $\dot{\varepsilon} \mu \pi$. - unclear as a label, but understandable as an affirmative

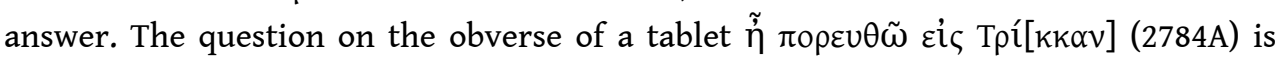

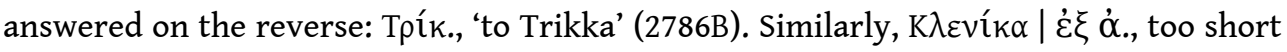
to be understood as a summary or a label, may be the response to Klenika's question

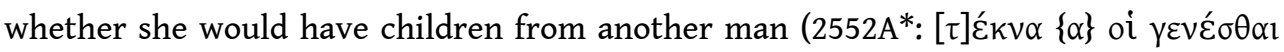

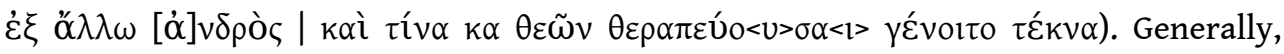
many single words found on the tablets make better sense as answers than as labels:

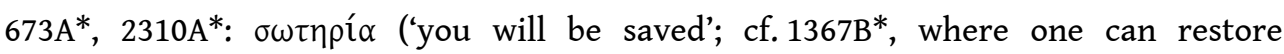

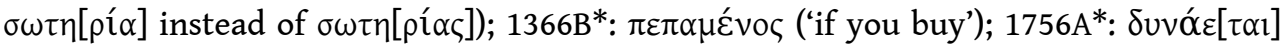

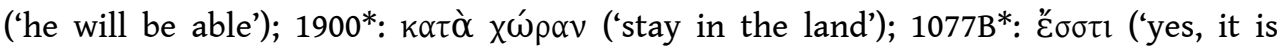




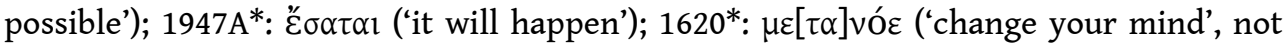

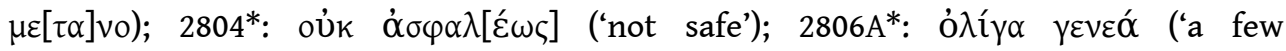
descendants'). Many tablets must be responses to the question 'to whom should I sacrifice?' (see below)].

A good number of texts refer to signs ( $\sigma \alpha \mu \varepsilon \tilde{o} o v, \sigma \eta \mu \varepsilon i ́ \alpha, \sigma \alpha \mu \alpha i ́ v \varepsilon v v ; 60 \mathrm{~A}, 188 \mathrm{~A}, 408 \mathrm{~A}$, 268A, 495B, 989A, 1089B, 1609B, 1834B, 2189B, 2510A, 2937A, 3026A, 3179B, 3264B). $\mathrm{N}^{\circ}$ $2510 \mathrm{~A}^{*}$ is of particular interest, since it is a question of the city of Dodona concerning a

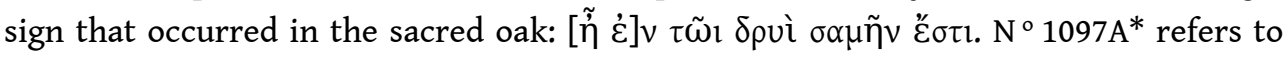
$\theta \varepsilon \circ \mu \alpha v \tau \varepsilon i ́ \alpha$. Several texts name diviners. A long but fragmentary example preserves the question of Timothea, a professional practitioner of this art. It refers to sacred things

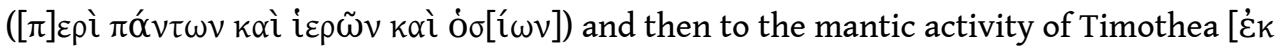

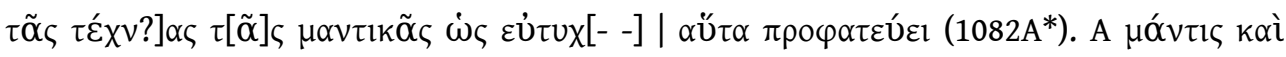

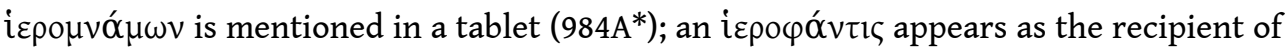

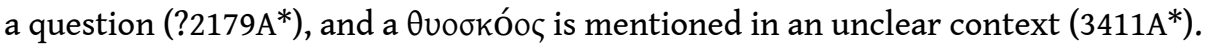

Sacrifice and other cult matters: A large group of tablets involves the questions of people who sought advice as to the gods and heroes to whom they should sacrifice or pray, or whom they should serve and propitiate, in order to achieve success, prosperity, and

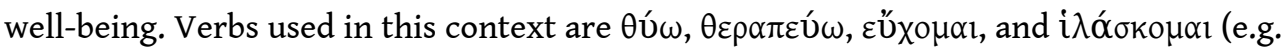
18B, 20A, 90, 138A, 145A, 361, 415A, 453B, 520, 565A, 573A, 602b, 608A, 622A, 633B, 636A,

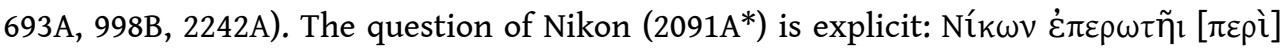

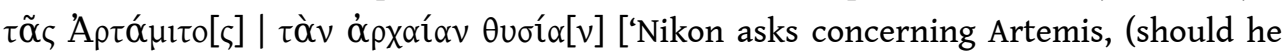
perform) the traditional sacrifice?]. Other gods that are mentioned in similar inquiries

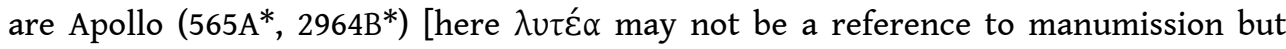
relief from divine punishment], Artemis (e.g. 541B*, 3192A*, 3393A), Aphrodite (987B*), Athena Polias $\left(109 A^{*}\right)$, Demeter $\left(623 B^{*}\right.$ ?), Ennodia $\left(2800 A^{*}, 2885 A^{*}\right)$, Herakles (restored in $746 \mathrm{~A}^{*}$ and $\left.806 \mathrm{~B}^{*}\right)$, Rhea $\left(3650 \mathrm{~B}^{*}\right)$, and Zeus Chamonaios $\left(1552 \mathrm{~A}^{*}\right)$, whom the eds.

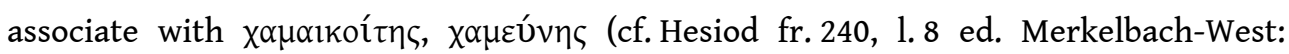

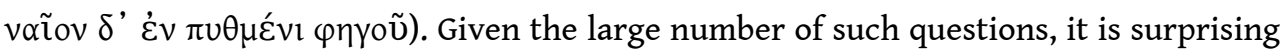
that the eds. have identified very few tablets as responses: e.g. 1045A*: A

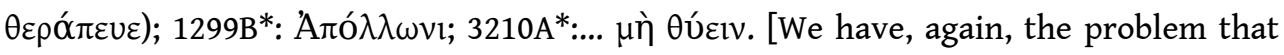
texts that are interpreted as labels or are restored as questions may in fact be answers.

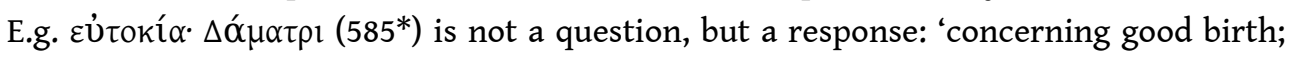
(sacrifice/pray) to Demeter'. $\Delta \mathrm{i}$ ' (1472B*, 'sacrifice to Zeus) is an answer. The

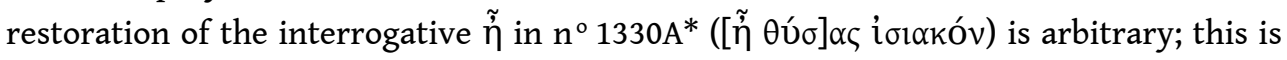
an answer: ' (you will be well), if you offer an Isiac sacrifice'; cf. the corresponding

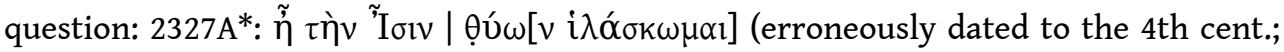
the text clearly belongs to the $3 \mathrm{rd}$ cent.). In $\mathrm{n}^{\circ} 2376 \mathrm{~A}^{*}$, a palimpsest, the letter $\mathrm{E}$ before

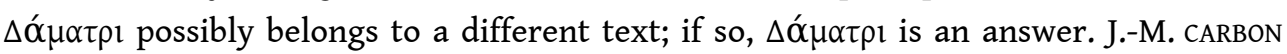
"Five Answers Prescribing Rituals in the Oracular Tablets of Dodona", Grammateion 4 (2015), p. 73-87, has plausibly identified more answers to similar inquiries (1122B*, 2035A*, 2393A*; SEG LVI 662; SEG XV 391)].

Apart from these questions about sacrifices, there are several other inquiries that concern ritual and religious matters. One tablet, for example, alludes to a ritual or a

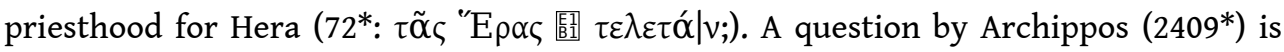
interpreted by the eds. as referring to the dedication of money to Athena: "A $\rho x ı \pi \pi \circ$

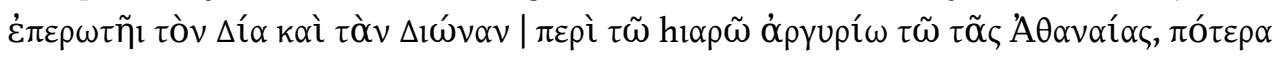




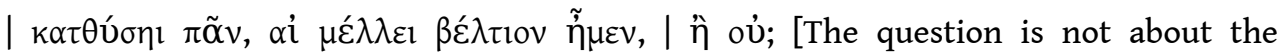
dedication of money. The money is already 'sacred'. Archippos, perhaps a priest, is asking whether he should use the entirety of the money for a sacrifice]. Eumedes asked Zeus Naios, Diona, and Tyche whether he should cut down an oak tree in a heroon

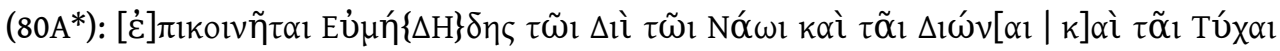

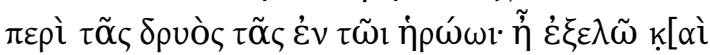

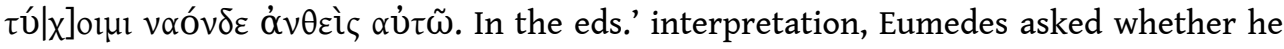

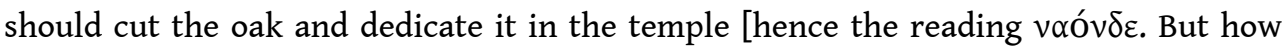
can one dedicate an oak tree in a temple - even in Dodona, with its particular connection to Zeus' sacred oak? A good reason for cutting down a tree is to use the space that is opened up, not to dedicate the timber. Perhaps we should read vaòv $\delta \grave{\varepsilon}$ (or voó $v<\tau>\varepsilon$ ): 'should I cut it down and will I be fortunate if I dedicate a shrine there?' For the cutting of an olive tree, again from a heroon, see 2432B*; cf. 2951A*]. Other

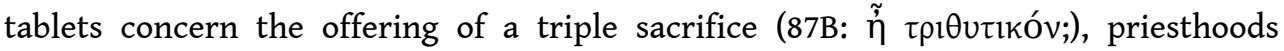

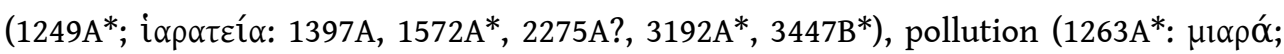

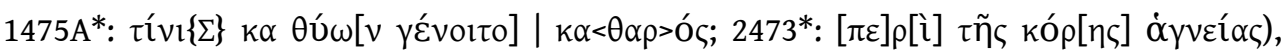

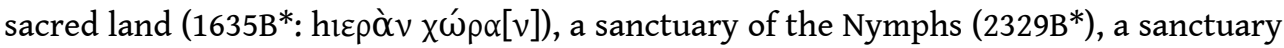
of Aphrodite (3479A*), an altar (2683*: $\beta \omega \mu$ õ̃), a sacred embassy (2769B*: $\theta \varepsilon \alpha \rho i ́ \alpha \varsigma)$, and the performance of funerary rites for a man suspected to be dead $\left(2980 \mathrm{~A}^{*}: \tau[\varepsilon \lambda \varepsilon \tilde{\mathrm{i}} v] \tau \grave{\alpha}\right.$

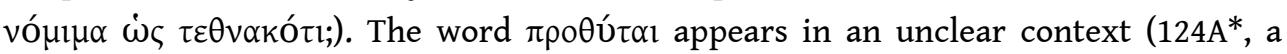
sacred office?, one who offers a sacrifice on behalf of another individual?). $\mathrm{N}^{\circ} 1102 \mathrm{~A}^{*}$ has the unattested verb [- -]v $\propto i \mu \alpha[\tau] \circ \varphi \circ \rho \varepsilon ́ o[v]$ (if it is not [- -]ṆA i $\mu \alpha[\tau \imath] \circ \varphi \circ \rho \varepsilon ́ o[v]$ ). Texts concerning magic have already been summarized in EBGR 1999, 36 (now $n^{\circ s} 172 A$ :

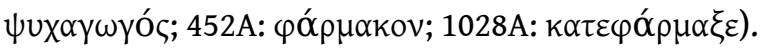

Religious mentality: [Some of the texts are interesting from the perspective of religious

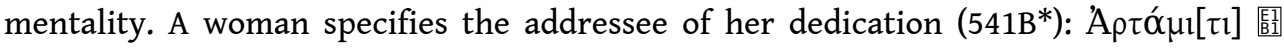

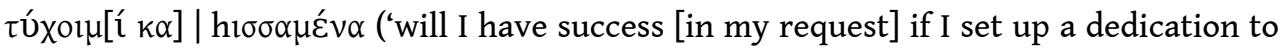
Artemis?'); here, the dedicant wants to make sure that her action will not be in vain. Another exemplary case of implicit negotiations between the worshipper and the god is found in a text in which a man does not neglect to point out to the god that a quick

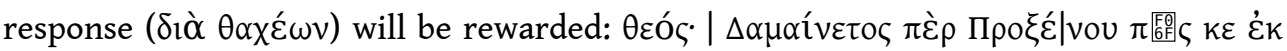

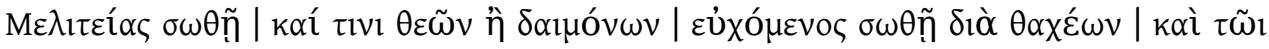

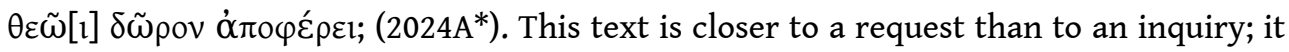
is a cry for attention. In a few cases, one recognizes signs of orality, as when the

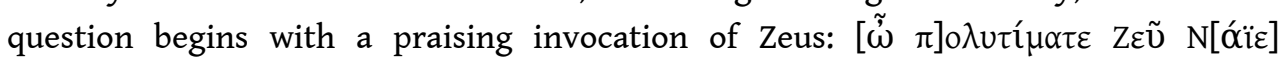

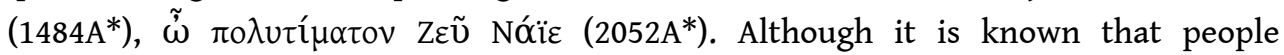
consulted more than one oracle, it is still interesting to observe that a pilgrim asked the gods of Dodona whether he should instead consult another oracle (if the restoration is

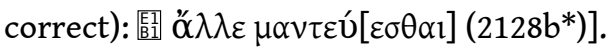

Legal matters: Many texts refer to lawsuits, legal disputes, and crimes: 33B: Eủ $\rho[. ..] \times \omega v \mid$

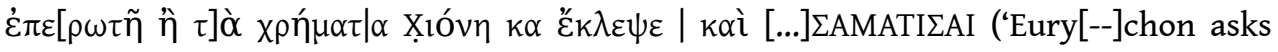

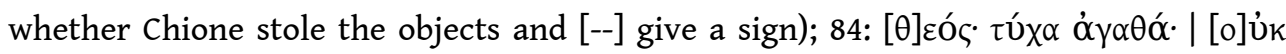

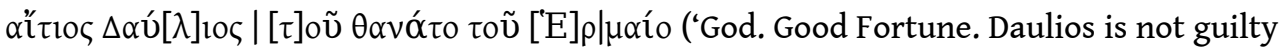

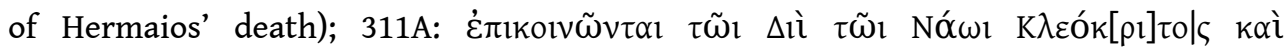

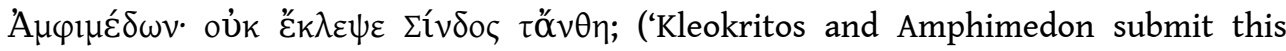

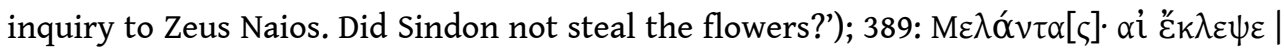




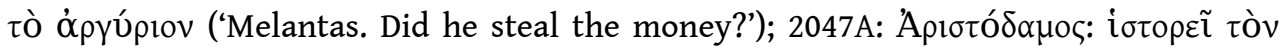

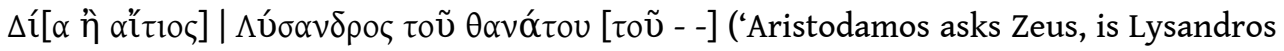

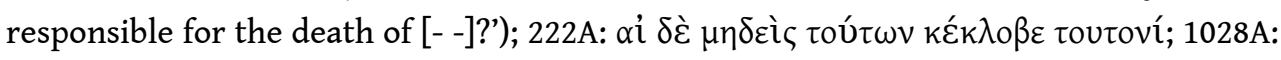

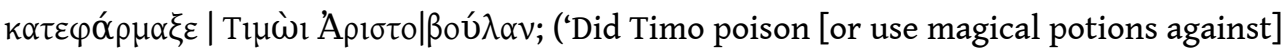

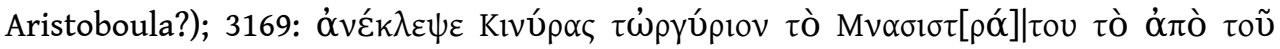

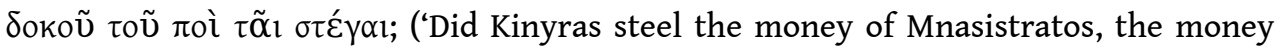
that was in [under] the beam on the roof?'; see also 4, 36B, 56A, 149, 176A, 201A, 214A, 272A, 423B, 435B, 448A, 452A, 454, 473B, 548B, 631, 637B, 694A, 747B, 759, 877A, 934A, 1012A, 1088A, 1124B, 1141B, 1170A, 1199B, 1368B, 1646A, 1771B, 1845A, 2005A, 2006A, 2037B, 2161A, 2332A, 2482A, 2510, 2619B, 2623A, 2643B, 2709A, 2767A, 2780, 2976A, 2977B, 3041A, 3043B, 3117A, 3176A, 3274A, 3321B, 3327B, 3340B, 3356B, 3407A, 3968B, 3045A, 3400A, 3478A, 3881, 4015, 4188A). As I shall argue in a forthcoming article, inquiries about crimes that mention the suspect had a function similar to that of exculpatory oaths. $\mathrm{N}^{\circ} 56 \mathrm{~A}^{*}$ refers to the theft of a phiale from a sanctuary of Poseidon

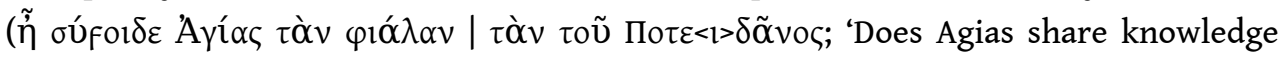
concerning the [stolen?] bowl of Poseidon?'). $\mathrm{N}^{\circ} 1012 \mathrm{~A}^{*}$ seems to refer to the theft of a

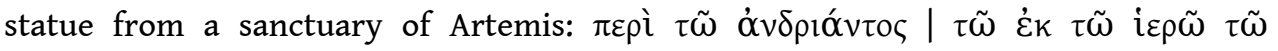

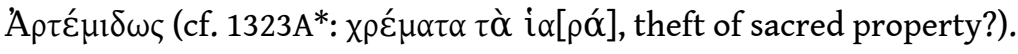

Disease and healing: The number of texts pertaining to divine healing and disease has significantly increased (healing: 97A, 299A, 473B, 556A, 1055B, 1143A, 1780A, 2032B, 4126A; disease: 118B, 139A, 299A, 384A, 556A, 573A, 730B, 968A, 1375B, 1393, 1466B, 1712A, 1803A, 1921A, $2090 \mathrm{~B}, 2145 \mathrm{~B}, 2193 \mathrm{~A}, 2329 \mathrm{~B}, 2379 \mathrm{~B}, 2664 \mathrm{~A}, 2879 \mathrm{~A}, 2911 \mathrm{~A}, 3119 \mathrm{~B}$, 3204B, 3296B, 3524B, 3528A, 3907, 3933B; health: 203B, 313A, 337B, 359B, 382A, 556A, 558B, 581A, 653B, 708A, 815B, 878A, 906B, 1098A, 1130B, 1217A, 1241B, 1271B, 1369B, 1377B, 1384A, 1393, 1402A, 1506A, 1558B, 1572A, 1581A, 1744A, 2059B, 2134A, 2165B, 2167B, 2242A, 2279A, 2304A, 2401, 2440, 2447A, 2462A, 2468A, 2510, 2525A, 2560B, 2641A, 2673A, 2681A, 2719A, 2763A, 2914A, 3044B, 3060A, 3084A, 3174A, 3177A, 3363B, 3397B, 3486B, 3508B, 3541A, 3989A, 4004A). The earliest tablet (968A*, late 6th cent.) not

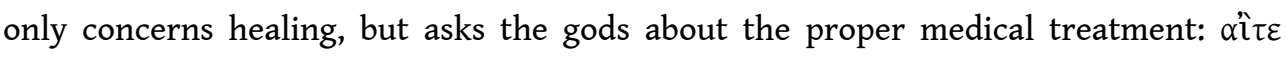

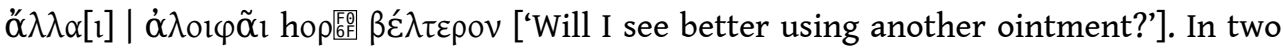
cases, the worshippers are worried that a disease may be a divine punishment: $\Xi \dot{\varepsilon} v \omega v i$.

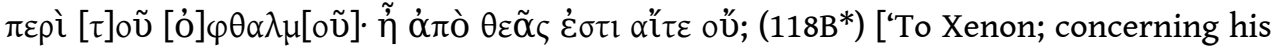

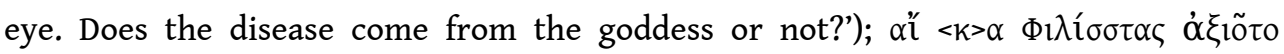

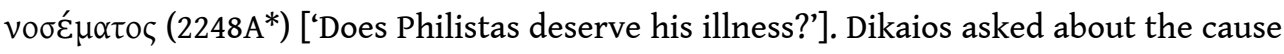

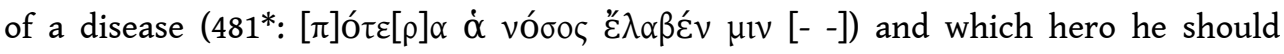

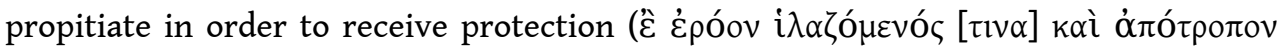
$\pi \circ \varepsilon ́ \sigma \alpha\left[\varsigma\right.$ - -]). A pilgrim asked which sacrifice would heal his pain $\left(139 \mathrm{~A}^{*}\right.$, very

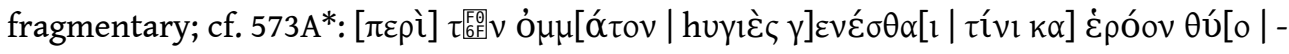
- -] [or $\theta u ́[o v] ;)$. In another text, a man and his relatives approached the gods concerning an ocular disorder of their fathers, and how this could be stopped: $\theta \varepsilon o ́ \varsigma$,

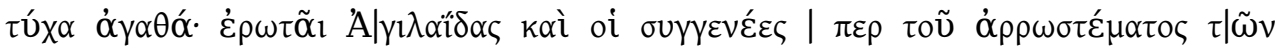

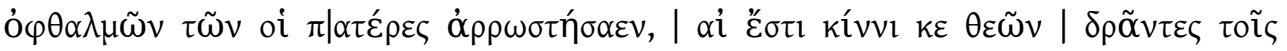

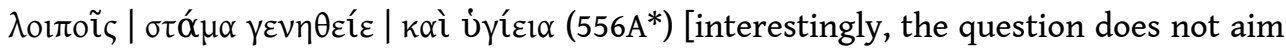
at healing the fathers but at stopping the disease (again, divine punishment?) from

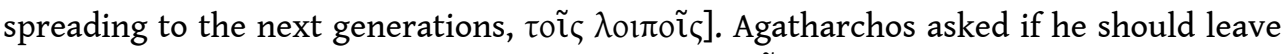

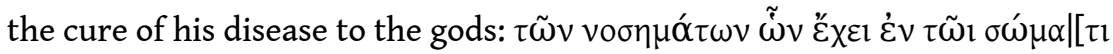

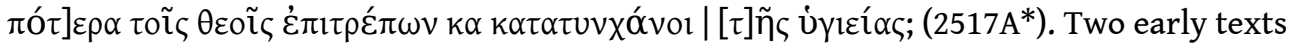


mention the healer Paiania (cf. Apollo Paionios), expected to heal a disease by putting

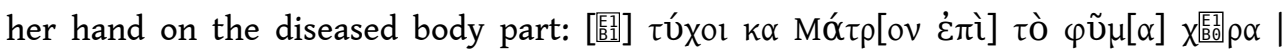

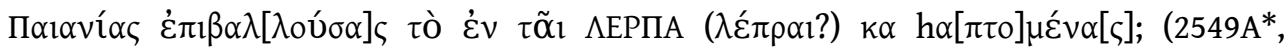
ca. 450 ; cf. $\left.3174 \mathrm{~A}^{*}\right)$.

38) L. D'AMORE, M. MARI, "Technitai, sacerdoti di Atena e atleti ad Anfipoli nel I secolo A.C.", Mediterraneo Antico 16.1 (2013), p. 223-256: Ed. pr. of a stele from Amphipolis, copied by C. Edson in 1938 and until now unpublished in its entirety. The stele has three inscriptions engraved at different times: a) an honorific inscription (see SEG XLVIII 716ter), b) a list of victors in athletic contests, and c) a Christian epitaph. The original inscription, presumably set up in the sanctuary of Athena, commemorates the crowning of four priests of Athena by an association of technitai. Two of these priests, possibly those responsible for setting up the stele, report that they crowned their бuvirpeĩ ( $90 / 89 \mathrm{BCE})$. The eds. interpret the koinon ton techniton as the local branch of the Dionysiac theater artists and assume that the priests were honored for an undetermined benefaction towards the association [though this does not explain why two priests honored their two colleagues]. At some time later, the names of victors in athletic contests (perhaps also the names of the agonothetai) were inscribed within wreaths rendered in relief. The victor's list is fragmentary, but it seems that it recorded victories in races (stadion, dolichos), wrestling, boxing, pankration, and pentathlon in

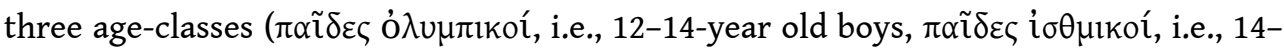
17 -year old ephebes, and ö $v \delta \rho \varepsilon \varsigma)$. The name of the contest is not preserved, but the participation of adult men excludes contests held in the gymnasion. A secure identification of the festival is not possible, but it may have been a festival of Athena. It is is likely that the Dionysiac technitai mentioned in the earlier inscription had participated in the same agonistic festival. In an addendum, the eds. note the recent publication of a second honorific inscription for priests of Athena from Amphipolis, again set up by a koinon ton techniton (SEG LXI 461; EBGR 2012, 93). [The fact that the honorific inscription of the technitai appeared on a victor's list can now rule out the hypothesis that the technitai were not theater artists but artisans].

39) P. DEBORD, "Le pays de Colophon (Colophon, Claros, Notion) et les Séleucides", REA 115 (2013), p. 5-27 [BE 2014, 57]: Ed. pr. of inscriptions from Kolophon and its territory.

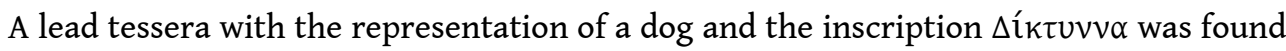
in the sanctuary of Apollo Klarios (p. 12-14, ca. 200). P. associates this object with the establishment of the cult of Zeus Kretagenes and Diktynna in Karia under Antiochos III and the administrative reform of $209 \mathrm{BCE}$, which placed all sanctuaries in the Seleucid territories in Asia Minor under the responsibility of the high priest Nikanor. A letter of Laodike to Kolophon (p. 14-17, ca. 200) is very fragmentary; only a reference to Apollo Klarios can be recognized. The subject of the letter may have been the recognition of privileges of the sanctuary at Klaros or the promotion of the Klaria to an agon stephanites. A column was dedicated to Apollo Klarios by a former prytanis in expression

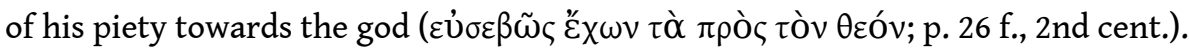

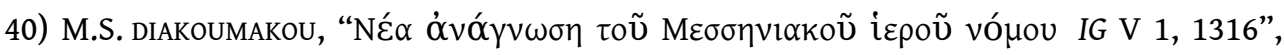
Horos 22-25 (2010-2013), p. 241-249: D. presents an improved edition of a sacrificial regulation for the cult of Zeus Kataibates from Thalame in Messenia (IG V.1.1316 = LSCG

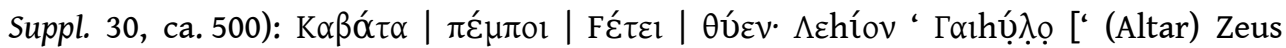
Kataibates; one should offer a sacrifice every fifth year. Lesion, son of Gaisylos']. The altar was dedicated by Lesion, probably at the site where Zeus' thunderbolt struck. 
211 41) A. DILER et alii, "Bodrum Yarimadasi Leleg Yerleşimleri Adalar, Aspat, Kissebükü (Anastasioupolis), Mylasa Damliboğaz (Hydai), Pilavtepe ve Sedir Adasi Yüzey Araştirmalari 2009", AST 28.3 (2010), p. 187-206 [SEG LXI 867]: Report on the discovery

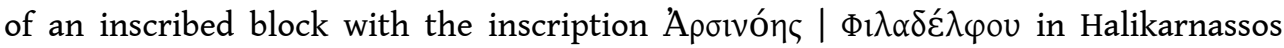
(p. 193 f.; 3rd cent.). [It must be an altar for the domestic cult of Arsinoe Philadelphos; cf. infra $\left.\mathrm{n}^{\circ} 105\right]$.

212 42) M. DINç, "Reliefs of a Marine Thiasos from the Tralleis Bath", Olba 20 (2012), p. 201244: The caldarium of the baths in Tralleis (Imperial period) were decorated with reliefs representing a marine thiasos. Some fragments have labels identifying the represented figures. One of them is fully preserved and identifies an Oceanid seated on the back of a

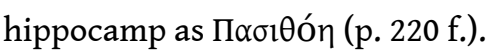

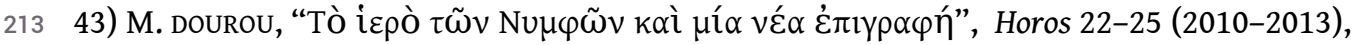
p. 199-208: Ed. pr. of a rock-cut inscription found in the sanctuary of the Nymphs in Athens (ca. 450). The inscription refers to the Athenian genos of the Koneidai, named after Konnidas, the educator of Theseus. The presence of a very ancient Athenian genos in this sanctuary underlines the political importance of the sanctuary of the Nymphs.

214 44) S. DURUGÖNÜL, D. KAPLAN, U. TEPEBAş, “Adrassos'da (Isauria) Paganizm ve Hiristiyanlik Arasinda Bir Lahit", Adalya 16 (2013), p. 261-264: Ed. pr. of a sarcophagus from Adrassos

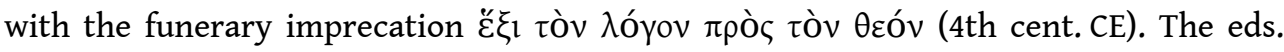
point to the ambiguity of this formula, which may be Christian or pagan.

215 45) C.A. FARAONE, "Magical and Medical Approaches to the Wandering Womb in the Ancient Greek World", Classical Antiquity 30 (2011), p. 1-32: F. discusses amulets for women that aimed at making the womb stay in its place [cf. EBGR 2004, 80; 2007, 89]. The view behind such amulets was that the womb moved freely about a woman's body, causing spasmodic disease. The wandering womb was imagined as a wild animal, which could be controlled with the use of fumigation rituals.

216 46) W. D. FURLEY, "The Epidaurian Hymn for the Mother of the Gods", in Hymnes, p. 233251: F. presents a critical edition of the hymn for Meter Theon in Epidauros (IG IV ${ }^{2}$. 1.131; FURLEY/BREMER, Hymns 6.2), which 'had at least its spiritual roots in the fourth century BC even if the text itself is somewhat later'. We present his translation: 'Goddesses [of music] come down from heaven and sing with me a hymn to the Mother of the Gods; how she came wandering over the hills and vales, trailing her hair in the dirt, distraught in her senses. Zeus the king observed her, the Mother of the Gods, aimed his thunderbolt and made to take her drums, he split rocks in two and made to take her drums. "Mother, be off to the gods! Don't wander over the hills in case the keen-eyed lions or grey wolves catch you...” And: “... I won't go off unless I receive my share: a half of the sky above and a half of my own earth and a share of ocean too. Only then I will depart." Hail! Great Queen! Mother of all Olympus!' Adducing various sources, especially Clement' comments on the mysteries of Deo/Demeter (Protrepticus II, 15) and the Derveni papyrus, F. explains Meter's anger as the result of a sexual assault on her by Zeus. By attempting to take Meter's drums, Zeus struck at the heart of her identity and attempted to force her into submission. However, Meter stood firm against his threats and compelled Zeus to accept her demands of a share of the earth, sky, and ocean.

217 47) N. GIANNAKopoulos, "The Gerousia of Akmonia", Gephyra 10 (2013), p. 13-31 [BE 2014, 468]: G. republishes and discusses three inscriptions from Akmonia (SEG LVI 1489-1491) 
[cf. EBGR 2006, 115] and summarizes the information they provide for the gerousia in this city. The second text (SEG LVI 1490) is of religious interest. It honors Demades,

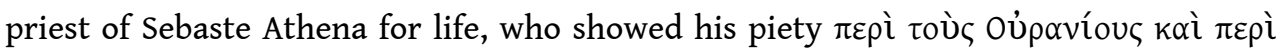

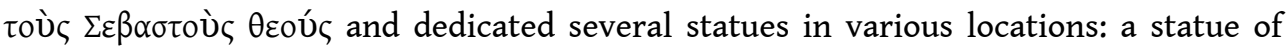

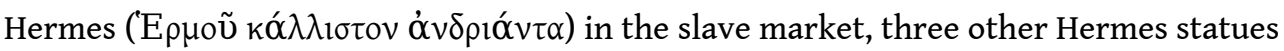
near the gate, statues of Demos, Polis, and Gerousia, and a statue of Zeus Keraunios in

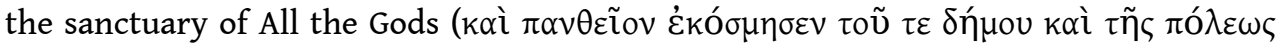

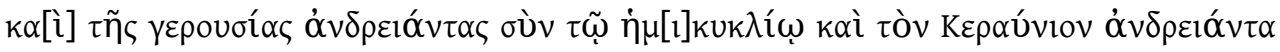

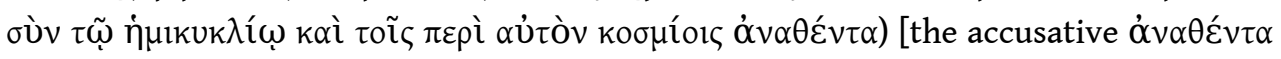
should be corrected to $\alpha \dot{\alpha} \alpha \varepsilon i$ ć, since Demades' name is in the nominative (line 1); 'and he adorned the Pantheion by dedicating statues of the Demos, the Polis and the Gerousia, together with the semicircular exedra, and the statue of Keraunios together with the semicircular exedra and the ornaments around the statue'; cf. G. Petzl's translation in SEG LVII 1490. On Pantheion, see infra ${ }^{\circ} 114$ ].

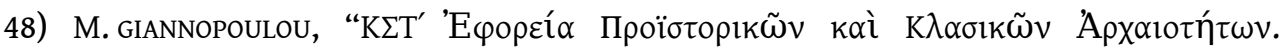

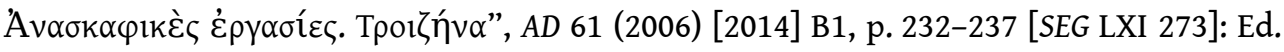

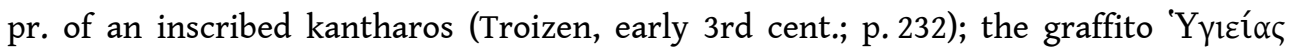
shows that it was used for libations [to Hygieia or to health].

49) M. GONZALES, "The Shrine of Asprachoma Near Mycenae and its Dedications from the Persian Wars", ZPE 184 (2013), p. 131-138: The finds from a sanctuary of Enyalios near Mykene include weapons dedicated to the war god (SEG XXIII 186-187). G. republishes an inscription from this sanctuary (SEG XXII 260, early 5th cent.), which he interprets as

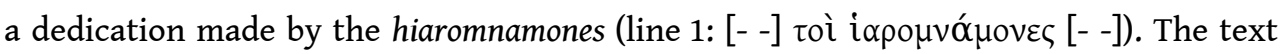
consists of a list of weapons (shields, helmets, javelins) and the names of 7 or 8 dedicants, whom G. identifies as members of the board of hiarmomnamones (two from

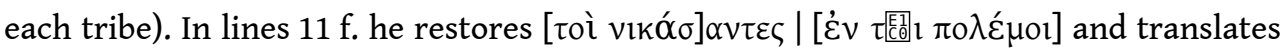
'having been victorious in the war' [then the restoration should be [vikóo] $\sigma v \tau \varepsilon \varsigma \mid[\dot{\varepsilon} v$

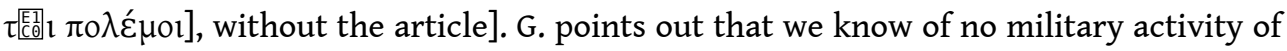
Mykene after the battle of Plataia and identifies the dedicated weapons as part of the officially alloted spoils from the Persian camp. [However, there is no proof that the 7 or 8 names are the names of hiaromnamones, the dedication of the weapons by sacred officials and not by military commanders would be odd, and it remains unclear why the weapons were dedicated individually and not collectively. There is a simpler explanation: this is not a dedication but an inventory of weapon dedications and their dedicants, made by the hiaromnamones in their capacity as supervisors of the sanctuary. The association of these dedications with the Battle at Plataia is an attractive hypothesis].

50) M. GonZALES, "Lost Dedications Commemorating Rhodian Victory Over Antiochos III", ZPE 184 (2013), p. 172-174: G. republishes a dedication to Zeus Soter, Athena Soteira, Poseidon Asphaleios, Artemis Orthosia, Herakles, Ares, Athena Areia, Enyo,

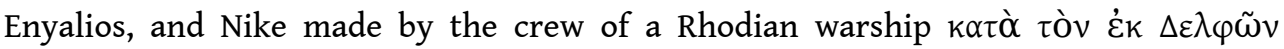

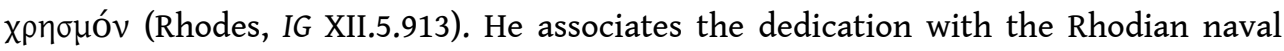
campaigns against Antiochos III in 191-190 BCE.

51) D. HEGYI, "Der sogenannte Gadatas-Brief: eine authentische Kopie oder die Erdichtung von Priestern?", AAntHung 50 (2010), p. 349-360 [SEG LXI 1252]: H. discusses the letter of Darius I to Gadatas, which concerns Apollo's sanctuary in Aulai; the letter is known from a copy of the early 2nd cent. CE (Magnesia on the Maeander; I.Magnesia 
115) [cf. EBGR 2009, 88 bis]. She argues that the letter is authentic. In her view, the priests mentioned in the letter (line 23) did not serve in a sanctuary in Magnesia or Aulai; there was no important cult of Apollo in Magnesia; the sacred cave at Aulai did not provide space suitable for the orchards alluded to in the text. Apollo's sanctuary was that in Tralleis (cf. I.Tralleis 17 and 20). The letter was sent to Magnesia because this city was the seat of the satrap of Karia.

52) W. HELD, Gergakome. Ein 'altehrwürdiges' Heiligtum im kaiserzeitlichen Karien, Tübingen, 2008: H. presents a detailed study of the topography of the sanctuary at Gergakome, the architecture of the monuments, the dedications, and the inscriptions. After reviewing the various interpretations that have been proposed for the name Gergas, H. favors an association with the Karian word for 'Karians'. In this interpretation, the rock-cut

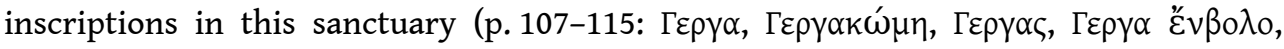

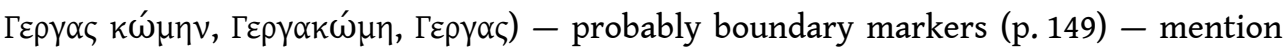
the epithet of the deity who was worshipped there, probably Kybele or Meter Karia (p. 147) [this interpretation can only be accepted if the nominative of the divine name

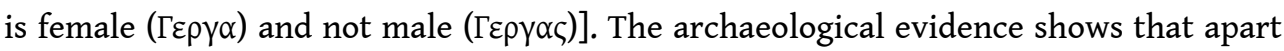
from Kybele, Marsyas and Apollo were also worshipped in Gergakome.

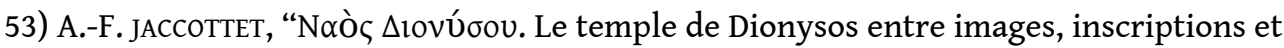
rhétorique", CCG 21 (2010) [2011], p. 249-267: J. discusses the meaning of the label voò $\Delta 1|[0] v u ́| \sigma o v$, which appears on a mosaic from Epiphaneia (Arabia, SEG XLV 1906), near the city vignette of Thebes. She identifies Thebes with the Boiotian (rather than the Egyptian) city, the birthplace of Dionysos' cult, but rejects a connection of the image with Euripides' Bacchae.

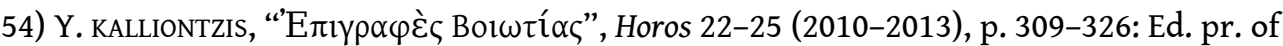
a dedication (of a sundial?) made to Helios and the Fatherland by Epaphras (5, unknown provenance in Boiotia, 2nd cent. CE).

55) Y. KALLIONTZIS, N. PAPAZARKADAS, “Tritopatreis in Boeotia”, ZPE 184 (2013), p. 165-171

[BE 2014, 205]: K.-P. republish an inscription from Thebes known only from a preliminary report (SEG XLIX 532, late 5th/early 4th cent.). In their reading, the text mentions the Tritopatreis, or ancestral divinities, of Arneion and his descendants:

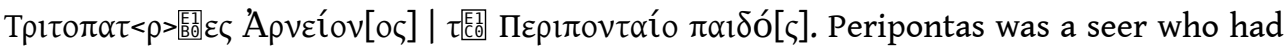
led King Opheltas and his people from Thessaly to Boiotia (Plut. Kimon 1.1-2, where

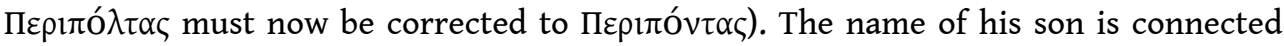
with Arne, the starting point of the immigrants to Boiotia, who upon their arrival in their new country founded a new Arne. The inscription probably came from a shrine and served as a marker of the deities worshipped there.

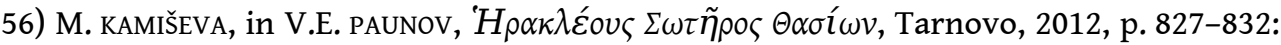
Ed. pr. of two dedications from the area of Augusta Traiana (2nd cent. CE). One dedication is addressed to the Thracian hero, with an epithet that derives from a Thracian village $\left(\left[{ }^{\prime} \mathrm{H}\right] \rho \omega \mathrm{s}\right.$ Bo $\left.\lambda \beta[--]\right)$. The addressee of the second dedication is not known; the dedicant made the dedication after entreating a god who listens to prayers

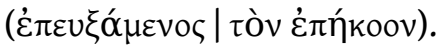

57) P. KATÓ, "Elite und Priestertümer im hellenistischen Kos", in Cities and Priests, p. 279301 [BE 2014, 372]: After a close examination of the methods of appointment in priesthoods and other cult offices in Kos, and of the social background of the holders of such offices, K. observes a significant difference between the demes and the polis. In 
the demes, the important priesthoods were assigned by lot and were, at least in theory, open to all citizens. On the contrary, the priesthoods of the polis were purchased, and were therefore occupied by members of the wealthy elite - offering them the possibility to publicize their high social status. K. examines in detail the epigraphic evidence for priestly and other cult offices, the finances of Koan cults, extra-ordinary services of cult officials, the purchase of priesthoods and the privileges associated with them, endowments for public cults, and private endowments. [A small detail, as regards

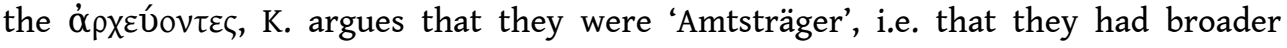
duties, not only religious; they only officiated in cults for which there were no priests.

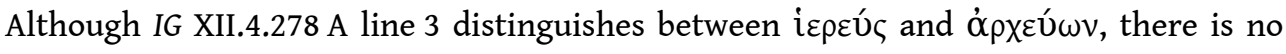

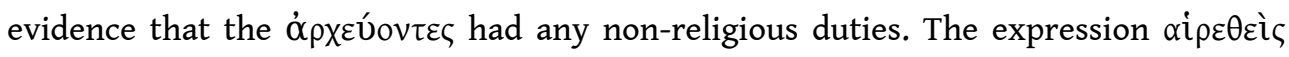

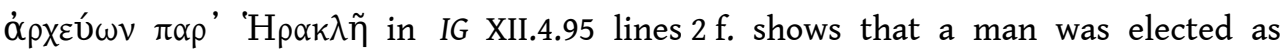
$\dot{\alpha} \rho x \varepsilon \dot{v} \omega v$ specifically in order to serve the cult of Herakles; this was the man's duty. All attestations of $\dot{\alpha} \rho \chi \varepsilon v ́ o v \tau \varepsilon \varsigma / \dot{\alpha} \rho x \varepsilon \dot{\sigma} \sigma \alpha v \tau \varepsilon \varsigma$ in Kos are connected with religious duties, either on behalf of demes or on behalf of tribes (IG XII.4.95, 100, 110, 456, 457). Why this designation was chosen is unclear; it is also noteworthy that in the cases of tribes (IG

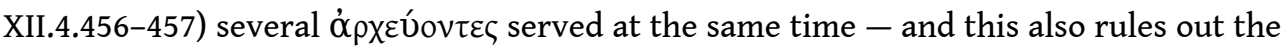
interpretation of these men as 'Amtsträger'; the term perhaps designates 'chairmen' of religious celebrations (e.g. banquets)].

58) Р. кAтó, "Von der Verlosung zum Verkauf des Priestertums oder umgekehrt? Bemerkungen zu einer lex sacra aus Antimachia (Kos)", ZPE 187 (2013), p. 211-214 [BE 2014, 373]: The regulation concerning the priesthood of Demeter from Antimacheia (IG XII.4.356 = LSCG 175, ca. 300-250) describes the procedure according to which the priestesses of Demeter would be selected by lot (lines 1-4). However, where the same text refers to financial obligations of women towards the sanctuary, it also mentions a

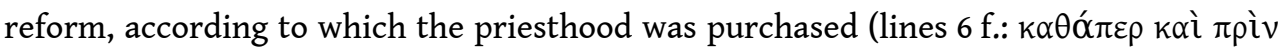

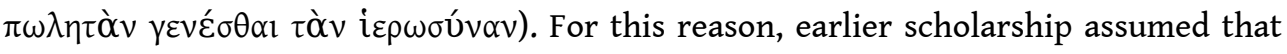
the appointment of priestesses by lot was replaced by the sale of the office. As K. points out, this is contradicted by the detailed description of the sortition. He suggests that the sale of the priesthood was replaced by sortition perhaps because there were not enough wealthy women interested in this office. [To be more precise: the original

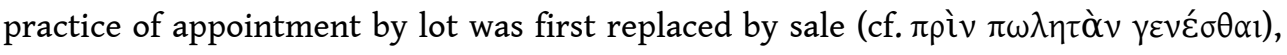
and then the Antimachians decided to return to the earlier mode of appointment].

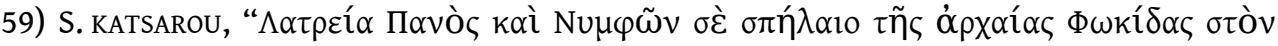

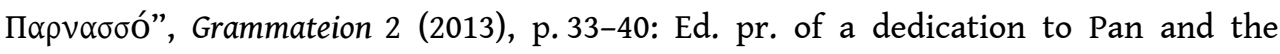
Nymphs, inscribed on a bronze sheet and probably once attached to a wooden box; it was found, together with other votives, in a cave on Mt. Parnassus near Agia Marina (ancient Patronis, 3rd cent.) [cf. EBGR 2012, 158: 4th cent.). K. briefly discusses other cults of Pan and the Nymphs in caves on Mt. Parnassus.

60) D.L. KellogG, "The Place of Publication of the Ephebic Oath and the 'Oath of Plataia", Hesperia 82 (2013), p. 263-276: The oath of the Athenian ephebes and the purported oath of the Greeks before the battle of Plataia (Tod, GHI 204) were published by the priest of Ares and Athena Areia in Acharnai (4th cent.). K. places this inscription in the context of the cult of Ares and Athena Areia in Acharnai, the local martial traditions there, and ephebic training and service in the frontiers of Attica.

61) J. KODER, S. LADSTÄTTER, “Ephesos 2009”, KST 32.2 (2011), p. 278-296: Report on the discovery of dedications in a sanctuary of Meter/Kybele on Panayırdağ (Ephesos). One 
of the finds (p. 279 f.) is a Hellenistic dedicatory relief depicting Meter with tympanon and phiale, seated on a throne with a lion on her lap. She is flanked by a bearded god (Zeus?, right) and a young god (left). Two dedicants stand in front of the young god. An inscription along the border identifies the goddess as Meter Patroia Hagia and the young god as Tiripates [we read the text from the ph.: Tipıлó

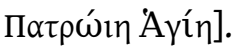

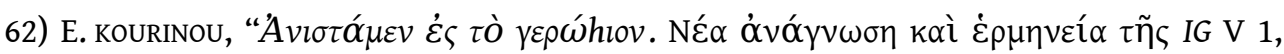
1317", Horos 22-25 (2010-2013), p. 251-260: K. republishes a puzzling inscription from Sparta (IG V.1.1317, ca. 350), written on a throne. The text reports that Nikosthenidas, a member of the Spartan gerousia, and his grandfather Nikosthenidas, made a dedication

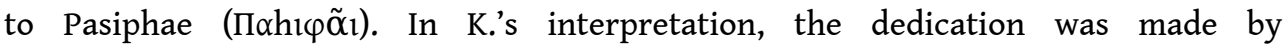
Nikosthenidas and his deceased grandfather to thank the goddess for an oracle that she had given to the ephoros Andrias, asking him to dedicate a statue of Nikosthenidas (the

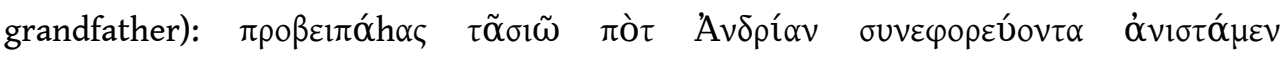

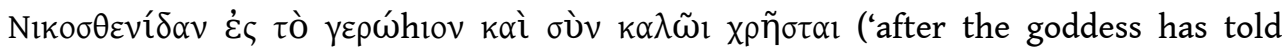
Andrias, his fellow ephoros, to set up a statue of Nikosthenidas in the building of the gerousia; then he will receive a good oracle'). K. speculates on the possible political background of the erection of Nikosthenidas' statue. [When the statue of Nikosthenidas

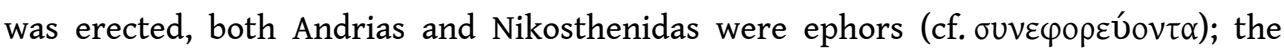
goddess' promise $\sigma \grave{v} v \kappa \alpha \lambda \tilde{\omega} \iota \chi \rho \tilde{\eta} \sigma \tau \alpha_{1}$ must be related with the divinatory duties of the ephors].

63) P. KOVÁCs, P. PROHÁSZKA, "Briefe an Theodor Mommsen aus Ungarn. Eine griechische Inschrift aus Viminacium", Acta Classica Universitatis Scientiarum Debrecen 48 (2012), p. 125-131 [BE 2014, 257]: In a letter sent to T. Mommsen in 1876, T. Ortvay, curator of the National Museum of Budapest, provides the transcription of an inscription that he

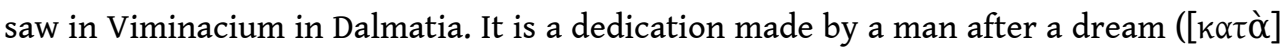
ǒveıрov).

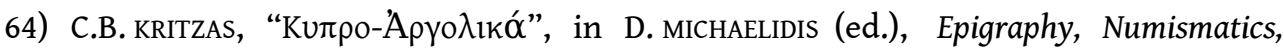
Prosopography, and History of Ancient Cyprus. Papers in Honour of Ino Nicolaou, Uppsala, 2013, p. 213-225: The bronze tablets from Argos that contain the accounts of the sanctuary of Hera in the 4th cent. [see EBGR 2007, 77] provide inter alia information on the agon for Hera, called Hekatombaia from the 5th-3rd cent., later Heraia, and from

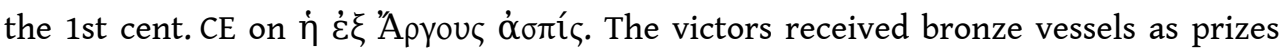
(hóf $f \varepsilon \theta \lambda \alpha$ ). In the late 4 th cent., King Nikokreon of Salamis made a donation of bronze precisely for these prizes (IG IV 583). Four h $\alpha$ f $\varepsilon \theta \lambda_{0} \theta \varepsilon \dot{\varepsilon} \tau \alpha$, assisted by two scribes (үрофعiٓ), were responsible for the contests. They received the funds for the contest

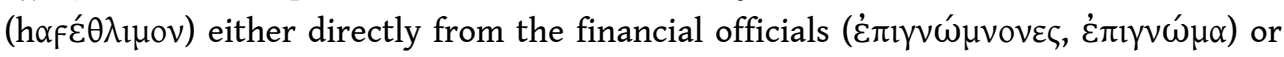

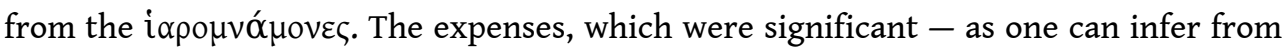
the large amounts mentioned in the tablets - were covered from revenues from the sanctuary (leasing of land, banking activities, booty, sale of confiscated property, sale of the skin of sacrificed animals). K. also discusses the contribution of the tablets to the reconstruction of the Argive calendar. The following sequence of months can now be established for the first half of the Argive year, which probably began in late June: Panamos, Agyieos, Karneios, Hermaios, Gamos, Amyklaios. The position of the remaining months (Agrianios, Apellaios, Arneios, Erithaieos, Teleos) is not certain,

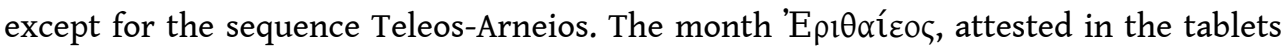
for the first time, is connected with farming activities (cf. है $p i \theta$ ○) and probably derives 


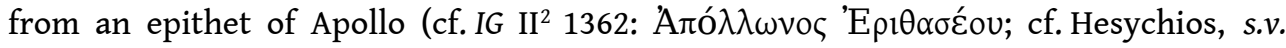
$\dot{\varepsilon} \rho 1 \theta \alpha \sigma \varepsilon \dot{v} \varsigma$ ). A sanctuary of Apollo Erithios existed in Argos in Cyprus (MIGNE, PG CIII col. 632). Apollo Erithios must have been a patron of fertility and agriculture (cf. other

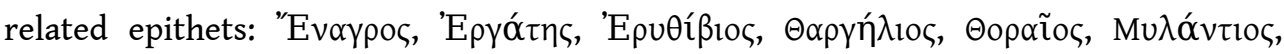

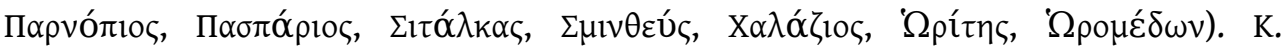
tentatively suggests that the month Erithaios derived its name from an unattested harvest festival (Erithaiea) celebrated in honor of Apollo.

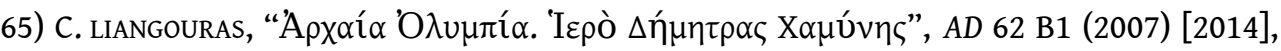
p. 429-431: The clay statuette of a cerberus was found in Olympia (undated), in the area

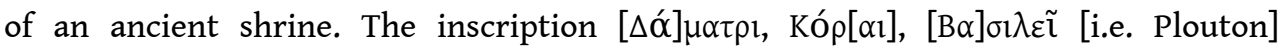
suggests that it was dedicated in the sanctuary of Demeter Chamyne.

66) S.R. LLEWELYN, J.R. HARRISON, E.J. BRIDGE, New Documents Illustrating Early Christianity X. A Review of the Greek and Other Inscriptions and Papyri Published between 1988 and 1992, Grand Rapids MI, 2012: The new volume of this series assembles a selection of inscriptions and papyri that pertain to aspects of society and religion at the time of the New Testament. The selected inscriptions (Greek texts and translations) include the following texts: 2) A funerary epigram for a certain Pythagoras (SEG XLII 1081, Philadelpheia, early 1st cent. CE). E.A. JUDGE discusses the connection of this text with Pythagorean ideas. 3) An amulet (SEG XXXIV 1666; XXXVIII 1924, unknown provenance, ca. 25-50 CE). This cameo - not necessarily a specimen of Jewish magic - is inscribed with one of the earliest attestations of formulas known from magical papyri and

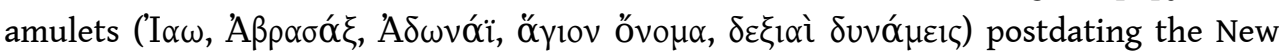
Testament. H. argues that the essential formulas of Greco-Egyptian magic had taken shape by New Testament times. 4) A magical gem (SEG XLII 1692, unknown provenance,

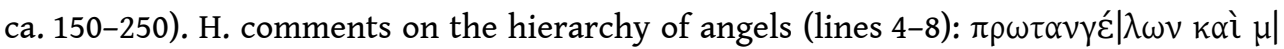

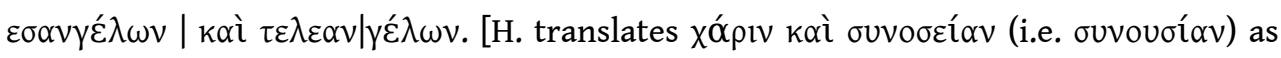
'favour and assistance'. In cult regulations and curses, ouvovoía unambiguously means

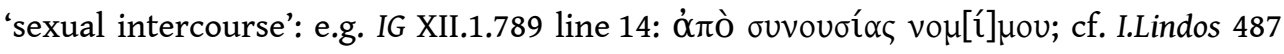

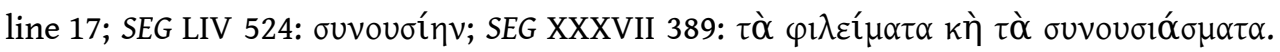
The owner of the gem wished for success in love]. 5) An incantation on a lead tablet (SEG XLI 1619, Fayum, 3rd/4th cent.). M. ALMOND comments on the voces magicae. The incantation aimed to cause oracular possession in a certain Alexandros. 6) Dedication of herms (I.Tralleis 11, Tralleis, ca. 14-37). The dedication was made by a priest of Tiberius

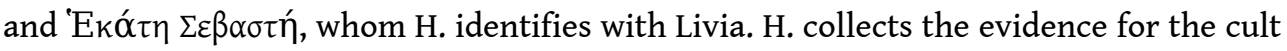
of Livia in the Greek East and her identification with goddesses (Aphrodite, Hera, Hestia, Demeter; esp. IG II ${ }^{2}$ 3241; IG XII Suppl. 124; SEG XLVIII 1129; IGR IV 180, 249, 319). 7) Honorific inscription for a priestess of Artemis from Ephesos (SEG XXXIX 1189, ca. 138-161); H. offers comments on the priestesses of Artemis, the summa honoraria they paid (cf. I.Ephesos 987 lines 22-24; 997 lines 6-17), their social background, their unmarried status, and their duties (cf. I.Ephesos 987 lines 1-27). 8) An oracle of Apollo against pestilence (Ephesos, shortly after $165 \mathrm{CE}$; MERKELBACH-STAUBER, SGO I 296 no 03/02/01); H. discusses the relation of Artemis to magic. 9) A dedication to Artemis by a neopoios (Ephesos, Imperial period, SEG XXXIX 1205); H. discusses the office of the

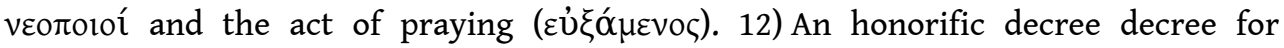
Tiberius from Messene (SEG XLI 328, 14 CE. [As I point out in SEG LXII 225, the oath

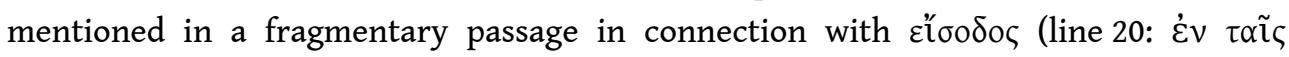

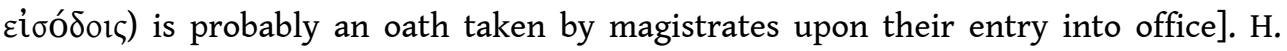


comments on the information that this inscription provides for the imperial cult in

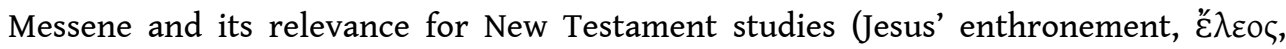

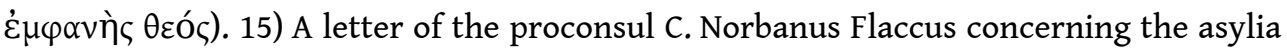
of Aizanoi (MAMA IX 13, ca. 17). B. SANDERSON discusses Flaccus' interference in favor of the Jewish population in Sardis and Ephesos [however, his assumption that this inscription 'also deals with non-interference in the performance of Jewish practices' (94) is not supported by the preserved fragment, which only mentions a request by

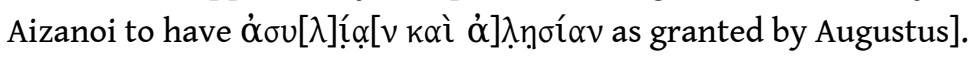

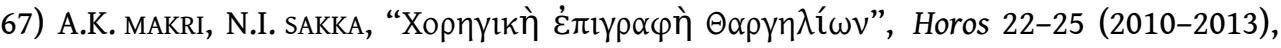
p. 155-162: Ed. pr. of an inscription commemorating the name of the victorious choregos at the Thargelia and the contributors to the victory (Athens, 372/1).

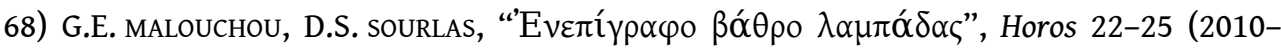
2013), p. 163-168: Ed. pr. of an inscribed base that supported a bronze torch dedicated to Hermes by a victor in a torch race, possibly at the Epitaphia (Athens, 1st cent. BCE/ $\mathrm{CE})$.

69) L.I. MaRangou, P.A. Matthaiou, “E

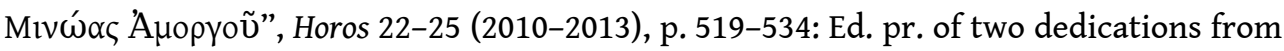
Minoa. The first text is a dedication to Soteira, probably Artemis (1, early 4th cent.). An altar was dedicated to Artemis Soteira by a man, who had sponsored the construction of a tower $(2,1$ st $/ 2$ nd cent.).

70) J.J. MARTINOVIĆ, Antički natpisi u Crnoj Gori. Corpus Inscriptionum Latinarum et Graecarum Montenegri, Kotor, 2011: The corpus of the Greek and Latin inscriptions from the area of the Bay of Kotor includes two dedications by peripoloi from the areas of Perast and Rhizon (I, II) [cf. EBGR 2012, 103] and a dedication to Artemis Elaphebolos from Ulcinium by an association of masons (ca. 400?).

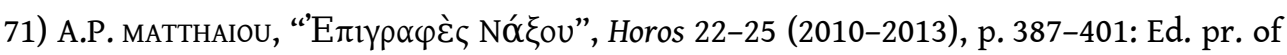
a fragmentary inscription from Naxos (1, ca.625-600), which can be tentatively

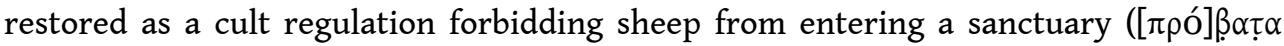

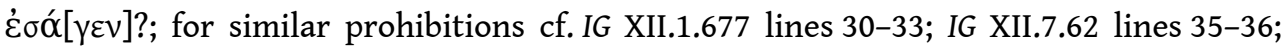

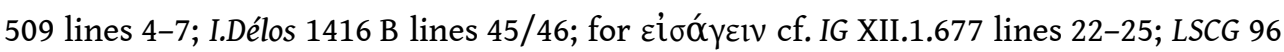
lines 6/7).

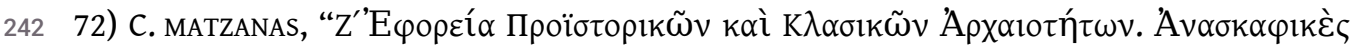

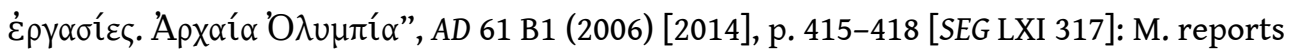
the discovery of a limestone base for a life-size bronze statue dedicated to Hera from Olympia (undated).

243 73) A. MEADows, "Two 'Double' Dedications at Ephesus and the Beginning of Ptolemaic Control of Ionia”, Gephyra 10 (2013), p. 1-12 [BE 2014, 412]: M. presents new restorations of two Ephesian inscriptions with 'double' dedications to royal couples and gods (I.Ephesos 199 and SEG XXXIX 1234). In his restoration, these inscriptions are dedications to Ptolemy V, Arsinoe, Sarapis, and Isis. M. collects another nine examples of similar 'double' dedications (eight from Egypt and one from Cyprus, ca. 240-116 $\mathrm{BCE})$. The Ephesian texts were dedicated by Egyptian military personnel, probably after the battle of Raphia (217 BCE).

74) B.W. MILLIS, S.D. oLSON, Inscriptional Records for the Dramatic Festivals in Athens. IG II ${ }^{2}$ 2318-2325 and Related Texts. Edited, with Introduction and Commentary, Leiden, 2012: M.-O. present a new critical edition and commentary of the Fasti of dramatic performances in 
Athens (IG II ${ }^{2}$ 2318, 2320-2325; SEG XXVI 203, 208; XXXVIII 162), proposing a new reconstruction of the relevant monuments and the placement of the fragments.

75) S. MITCHELL, D. FRENCH, The Greek and Latin Inscriptions of Ankara (Ancyra). Volume I. From Augustus to the End of the Third Century AD, Munich, 2012: The corpus of Ankyra includes 315 inscriptions, all from the Imperial period. New texts are marked with an asterisk. Contests: The most interesting texts concern a new musical contest established

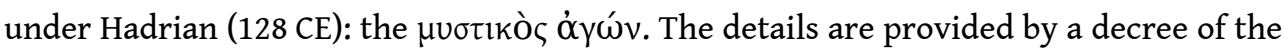

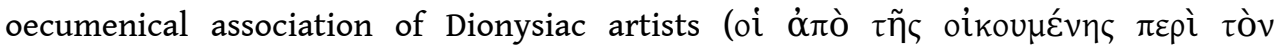

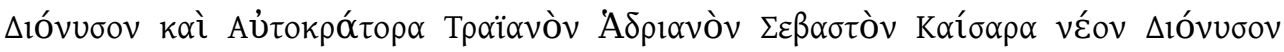

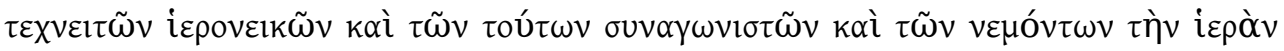

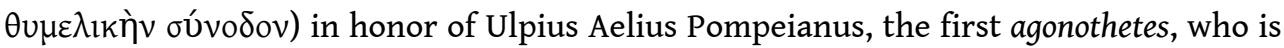
praised for his generosity and piety towards both gods (Dionysos and Hadrian). The new contest was approved by Hadrian at short notice. The first agonothetes 'summoned

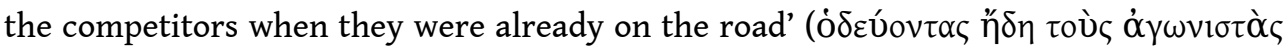

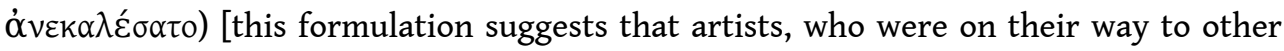
competitions, were called back to compete in the new festival]. Pompeianus' statue was to be erected in the theater, as a model of virtue for the spectators. Upon entering the contest, the competitors were to crown his statue, otherwise they were to be excluded on account of the lack of gratitude. The decree was inscribed on the right face of the statue base. The honorific inscriptions on the front of the base designate Pompeianus as Helladarches and high priest (140). Another Pompeianus (P. Aelius Pompeianus Paion, the new Homer) was responsible for the establishment of a similar mystikos agon in Side (I.Side II 70). The puzzling title of Helladarches, only attested for Pompeianus and the high priest Memmius [- -] Dionysios (141 line 48; 142; cf. 143 line 23), is only mentioned in documents related to the Dionysiac artists. Pompeianus was honored as $\dot{\varepsilon} \lambda \lambda \alpha \delta \alpha \rho \chi \eta ́ \sigma \alpha \varsigma$ also by a tribe (142) and by the Dionysiac association (143). The Dionysiac artists honored him during the celebration of an agon in another city, probably sometime after the first celebration of the mystikos agon in Ankyra (129 CE?):

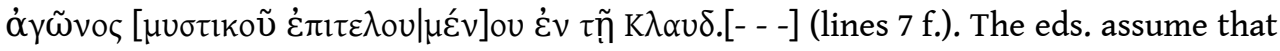

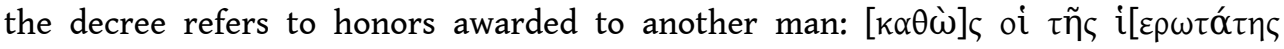

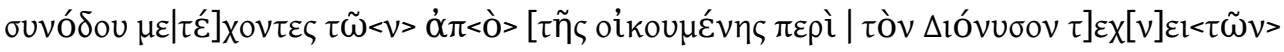

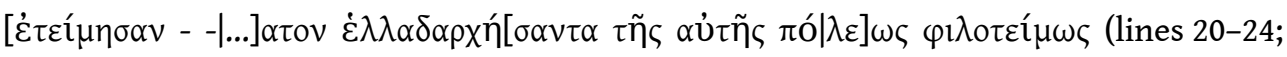
'just as those who have a share in the most sacred synod of the worldwide victors of sacred games and crown-wearers honored (?) Torquatus, having been helladarch in the same city with honor'). [The dossier concerning Pompeianus and the office of the Helladarches needs a more detailed discussion. I have doubts about a few restorations accepted by the corpus; here I present only a few preliminary observations. In the

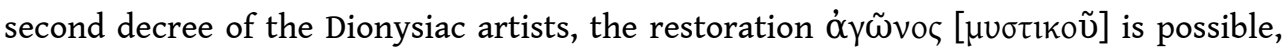
since there was another mystikos agon in Side, but it is far from certain. The eds. assume that this decree for Pompeianus refers to another decree for another man, a predecessor of his as a Helladarches. This is unlikely, and as a matter of fact it is very probable that Pompeianus was the first Helladarches. To judge from the photo, the partly preserved first letter on line 23 is not an A ([...] $\alpha \tau o v)$ but rather an E. There is also no reason to assume that the Helladarches mentioned in this line ( $\dot{\varepsilon} \lambda \lambda \alpha \delta \alpha \rho x \eta ́[\sigma \alpha--])$ is a person other than Pompeianus. The eds. probably assume this because they restore Pompeianus' name in the nominative in lines $15 \mathrm{f}$;; but this restoration is arbitrary; the name may well be in the accusative; also arbitrary is the restoration of a participle 


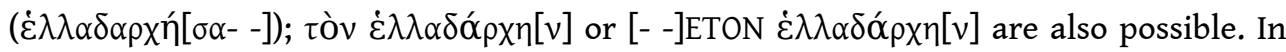
any case, these lines do not refer to a decree for a different Helladarches, a predecessor of Pompeianus in this office, but to the decree on the basis of which Pompeianus had

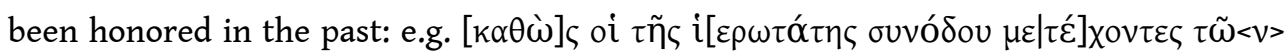

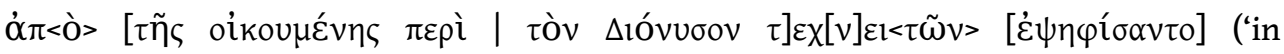
accordance with the decree issued by the members of the most sacred synod of the worldwide Dionysiac artists'). So, this inscription does not provide evidence for a predecessor of Pompeianus as Helladarches. The mention of such a predecessor of Pompeianus in another text (141 lines 45-49) is also unlikely: $\dot{\alpha} \gamma \omega \tilde{\omega} v o \varsigma$ $\tau \varepsilon \mid[\lambda \circ u \mu \varepsilon ́ v o v$

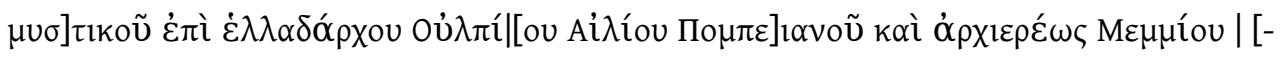

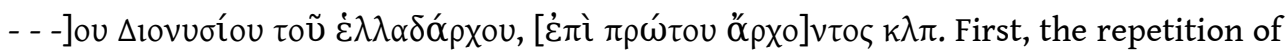
$\dot{\varepsilon} \pi \dot{l}$ in line 49 is not necessary. Second, in the year in which Pompeianus was

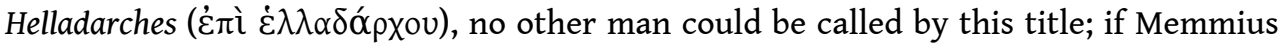
Dionysios had been a predecessor, he would have been referred to with the participle

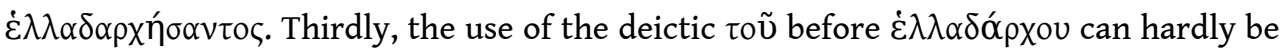
reconciled with the hypothesis that Memmius was a former Helladarches; instead, it

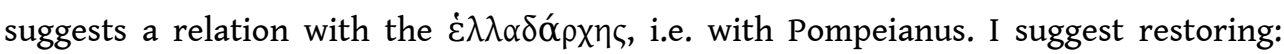

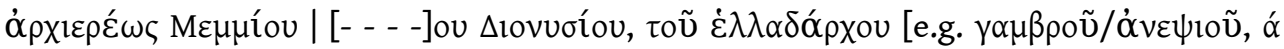

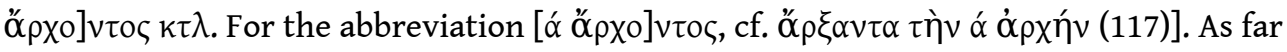
as we know, Pompeianus, the first agonothetes of the mystikos agon was also the first helladarches. What was the helladarches in Ankyra? This function was probably influenced but not related to the helladarchs of mainland Greece (Achaia); it is also unrelated to the honorific title (not office) $\pi \rho \tilde{\omega} \tau o \varsigma \tau \tilde{\omega} \nu{ }^{\prime} \mathrm{E} \lambda \lambda \eta \dot{\eta} v \omega v$ that was granted to Iulius Severus under Trajan $(72,78,79)$. In Ankyra the helladarches is only known in connection with dramatic and musical contests. One is tempted to assume that he exercised his function during that celebration, perhaps as the chairman of contests that represented Greek culture; the office is also discussed by M. VITALE, "Hellenistische Poleis, Hellenarchen und koina der Hellenen fern der 'Heimat'", Tyche 27 (2012), p. 175-177].

246 Evidence for the contest for Asklepios is provided by honorific inscriptions for

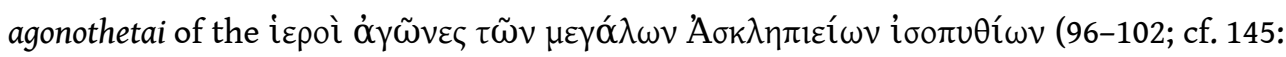

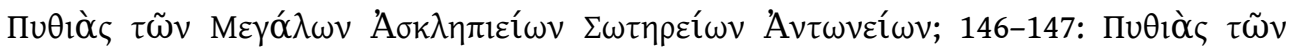

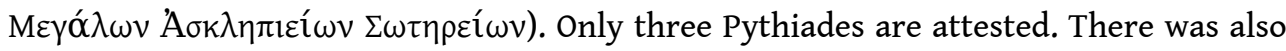

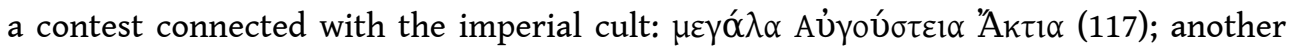
agonothetes (133) served in an unknown festival.

247 Imperial cult: The inscriptions inscribed on the walls of the temple of Roma and Augustus include the Res Gestae Divi Augusti (1; Greek and Latin text) and a list of priests of the cult of Augustus and Roma in Galatia (2; $5 \mathrm{BCE}-16 / 17 \mathrm{CE})$. This list refers to the benefactions of the priests. They regularly offered banquets ( $\delta \eta \mu \theta o i v i ́ \alpha)$, shows $(\theta \varepsilon \dot{\varepsilon} \alpha)$, gladiatorial combats and venationes, and olive oil for the gymnasium. Extraordinary services include the organization of processions, athletic and equestrian contests, the offering of sacrifices ( $\dot{\varepsilon} \kappa \alpha \tau o ́ \mu \beta \eta$ ), the dedication of imperial statues, the donation of space for a panegyris and horse races near the Sebasteion, and the distribution of grain. Gladiatorial combats and hunts of wild animals that lasted for 51 days are mentioned in $\mathrm{n}^{\circ} 144$; there are several epitaphs of gladiators and other gladiatorial monuments (148153, 155). An inscription mentions the priests of Augustus and first priest of Claudius (3) [see EBGR 2009, 106]. In addition to the high priests $(8,72,81-83,88,89,91-102,117-$ 
119; cf. the title Galatarches: $83,88,96-106,117,118)$, other officials of the imperial cult

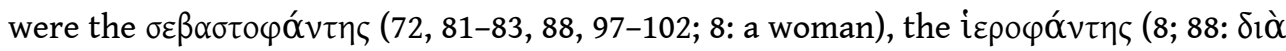
ßíov), and the agonothetes $(72,83,88,96-102)$. Under the heading the men who promised building works for their additional donations ( $\dot{\varepsilon} \pi \delta$ ó $\mu \alpha \tau \alpha)$ during their high priesthoods', an inscription mentions a high priest of Augustus and his donation (4; ca. $100 \mathrm{CE}$ ). One of the sebastophantai dedicated $\sigma \varepsilon \beta \alpha \sigma \tau о \varphi \alpha \nu \tau 1 k \alpha \grave{~} \chi \rho \eta ́ \mu \alpha \tau \alpha$ for construction work $(72 ; 114 \mathrm{CE})$; his honorific inscription also mentions that he made his wife high priestess ( formulation of this text supports the view that high priestesses owed their position to their male family associates, in this case to her husband, and did not acquire this rank entirely in their own right' (p. 229); this high priestess is honored with the text $n^{\circ} 78$; for another high priestess see $n^{\circ} 79$. A high priest served ten times (33), another two terms (83). A body of individuals (an association of iepoupyoí?) dedicated a statue of Antoninus Pius. There are several dedications to emperors (Trajan: 5-6; Hadrian: 7; Caracalla: 17-18; unknown emperors: 21, 23, 26-28) and the Theoi Patrioi and the emperors (30). Several acclamations of Severan emperors designate them Olympian Gods and Olympian (12-14).

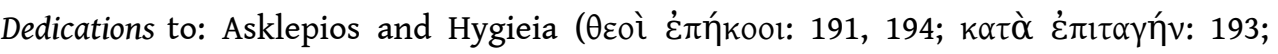
$\Sigma \omega \tau \tilde{p} \varepsilon \varsigma: ~ 194) ;$ Sol Aesculapius et Hygia (192; iussu eorum); Agathos Daimon Pater (195);

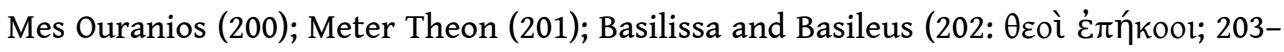
204); Zeus Megistos Taenos, i.e. Tavianus (205); Zeus Taouianos (206); Isis (197: kupí $\alpha$ ). The neokoros of Megas Sarapis set up statues of the Dioskouroi Soteres to Zeus Helios Megas Sarapis and the oúvvoor $\theta \varepsilon o$ for for the rescue the emperors, the council and the

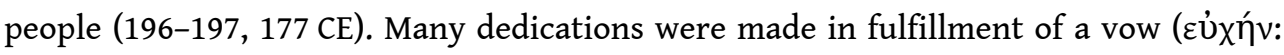

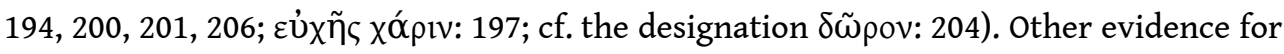
cults includes an altar for the cult of Hermes, Zeus, Selene, Ares, and Aphrodite (196). Two of the tribes derive their names from cults of Zeus: $\Delta$ ì̀ $T^{2} \alpha \pi \varepsilon \zeta \tilde{\omega} v(80,89,95,117$, 154 ii) and $\Delta$ iò $\varsigma$ Tạvoṽ (93). Cult personnel: Priests of Asklepios Soter for life (119), Basilissa and Basileus (203), Demeter (twice, 132), Dionysos for life (89), Tyche for life (117), Mes (118), Zeus Tavianus (205), priest and neokoros of an unknown cult for life (123), priest (129), priest of Sarapis (196-197), and neokoros of Sarapis (197-197). Cult buildings: A priest of Basilissa and Basileus dedicated a temple (бฤкóৎ) with votive offerings and an enclosure (203). Grave cult: An epitaph has a funerary imprecation

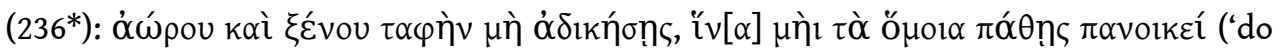
not wrong the tomb of a stranger and one who died before his time, in order not to suffer a similar fate with all your household').

76) C. MÜLleR, F. PRost, "Un décret du koinon des Ioniens trouvé à Claros", Chiron 43 (2013), p. 93-126 [BE 2014, 409]: Ed. pr. of a decree of the Ionian Koinon found in the sanctuary of Apollo in Klaros (ca. 180). The decree concerns the re-establishment by Kolophon of the pentaeteric panegyris and agon in honor of Apollo Klarios, which had been interrupted because of wars, probably in the late 3rd and early 2 nd cent.; the Kolophonians had only been able to perform the relevant sacrifices but not the contests. The Kolophonians were prompted to re-establish the contest by Apollo himself, who indicated his epiphany and presence in Klaros through divine signs

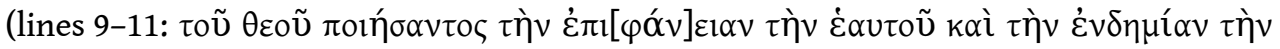

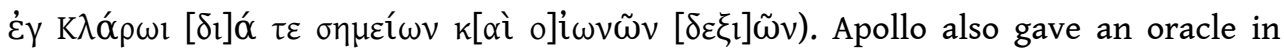

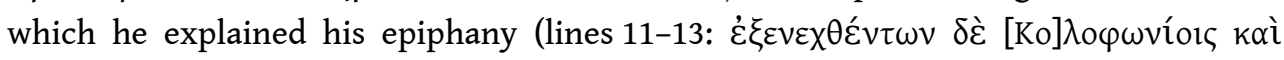




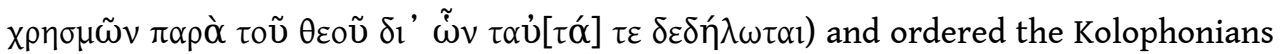
to organize a pentaeteric contest in Klaros in accordance with the custom of their ancestors. The Kolophonians fulfilled the god's wish. With its decree, the Ionian Koinon

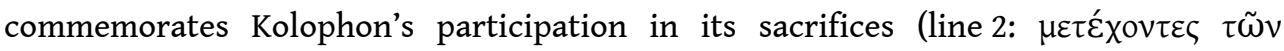
$\theta v \sigma i \tilde{\omega} v)$ - i.e., the sacrifices to Poseidon Helikonios at the Panionion, and possibly additional sacrifices during the festivals Antiocheia and Alexandreia and sacrifices to Thea Rhome - and declares its participation in the panegyris. The Koinon would send a theoria to Klaros. The envoys were to arrive in Klaros at the time of the sacrifice, attend the procession together with the priest, and jointly offer sacrifices to Apollo Klarios

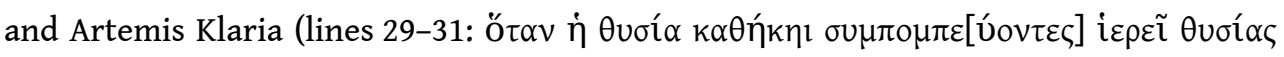

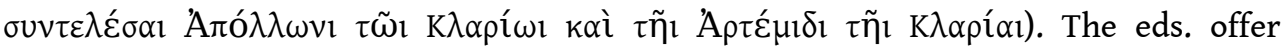
detailed commentary on the historical context, the Ionian Koinon, the Great Klaria, Apollo's epiphany and oracle, and the theoria of the Ionians.

77) F. Muscolino, "Bolli laterizi da Taormina", PP 67 (2012), p. 414-467: M. collects the stamps on tiles from Tauromenion (3rd-1st cent.). The inscriptions on some of the

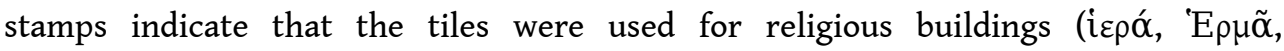

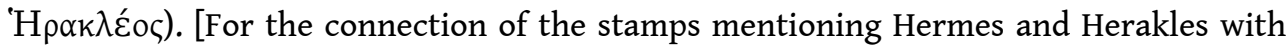
the gymnasion, see EBGR 2012, 132].

78) J. mylonopoulos, "Commemorating Pious Service: Images in Honour of Male and Female Priestly Officers in Asia Minor and the Eastern Aegean in Hellenistic and Roman Times", in Cities and Priests, p.121-153: M. discusses the epigraphic evidence for honorific statues for priests, priestesses, and other cult officials during the Hellenistic and Imperial periods, especially in Messene (sanctuary of Artemis), Kos, Priene (sanctuary of Demeter and Kore), Aphrodisias, and Stratonikeia. M's detailed examination of this material - including a critical review of earlier interpretations allows him to distinguish between different agents (the priests themselves, family members, civic authorities) and observe a strong difference between the rather modest honors for cult officials as compared to those for benefactors. Differences can also be noted in the locations that were chosen: statues of priestesses were usually placed near or in a sanctuary (rarely inside the temple), while statues of priests were erected in public areas (usually the agora) but almost never in places explicitly designated as the

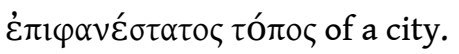

79) T.H. NIELSEN, "When Zeus Gave Me Victory. A Note on Inschriften von Olympia 166", Nikephoros 25 (2012), p. 155-158: N. discusses an unusual formulation in the honorific epigram for Troilos, an Olympic victor in an equestrian contest (IvO 166, mid-4th cent.):

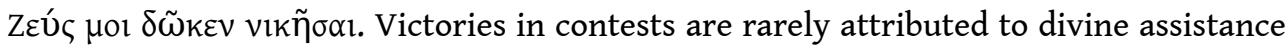
[for an example, see infra $\mathrm{n}^{\circ}$ 107]. However, Troilos' victory was highly unusual, as he won in 372 BCE while serving as Hellanodikes (Paus. 6.1.4). Possibly accused of partiality, Troilos interpreted his victory as a divine gift.

80) M. ÖZSAIT, G. LABARRE, N. ÖZSAIT, I. GÜCEREN, "Sites et statuts des communautés en Pisidie: l'exemple des Hadrianoi et des Moulasseis”, Adalya 15 (2012), p. 171-201: Ed. pr.

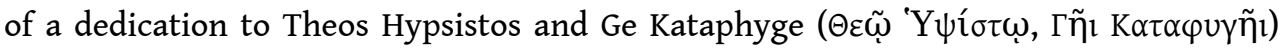
from the demos of the Moulasseis, near Hadrianoi (p. 185 no 2, 2nd cent. CE). For the

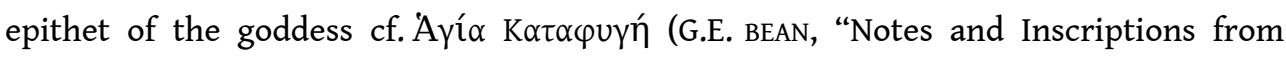
Pisidia. Part II", Anatolian Studies 10, 1960, 70 no 122). 


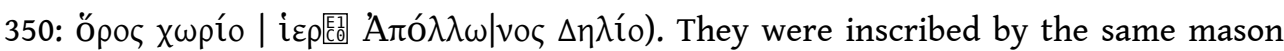
and found in close proximity one to another. A sixth similar boundary marker was already known (IG XII.5.214). The demarkated land probably belonged to the sanctuary of Apollo Delios in the isthmus of Despotiko. For the cult of Apollo Delios in Paros, P. adduces Pindar's 7th Paian, which refers to the foundation of a sanctuary by Herakles. This sanctuary is generally identified with a sanctuary at Bigla, where the cult of 
Artemis Delia is attested. P. plausibly associates the paian with the sanctuary of Despotiko.

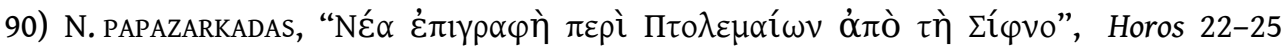
(2010-2013), p. 425-452: Ed. pr. of an important but fragmentary decree from Siphnos honoring a Ptolemy, either Ptolemy the Son (ca. 268-259) or more likely Ptolemy III shortly after his accession in $246 \mathrm{BCE}$. The text refers to recent military events and the traditional relations between Siphnos and the Ptolemies. The decree establishes an annual celebration (B lines 4-7), either in honor of the deified Ptolemies or the current

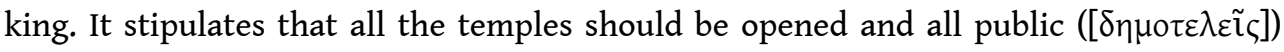
priests and priestess should offer sacrifices to the gods.

91) A. PERò, La statua di Atena. Agalmatofilia nella "Cronaca" di Lindos, Milan, 2012: P. offers a profound study of the second epiphany of Athena in the Lindian Anagraphe (I.Lindos 2, 99/98 BCE). According to this narrative, a man secretly entered the temple and hanged himself from beams behind the statue of Athena Lindia (D 27-42). In the commentary to this incident, P. studies in detail the legends surrounding the statue of Athena Lindia and the relevant literary traditions (p. 43-82), collects cases of suicide and death in temples (p. 83-94) and stories of men falling in love with statues (p. 95121), and comments on the purification of the statue (p. 123-135).

92) C.A. PFAFF, "Artemis and a Hero at the Argive Heraion", Hesperia 82 (2013), p. 277299: It is generally believed that cult activity in the Heraion of Argos was restricted to the cult of Hera. A graffito on a vase mentioning an anonymous hero (ca. 400-350; C.

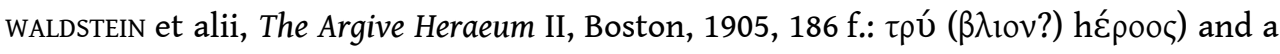
fragment of an altar of Artemis (IG IV 513; 4th cent.; read and restored by P. as A

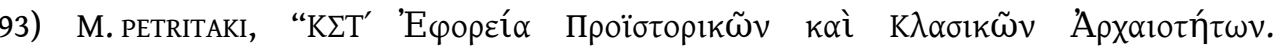

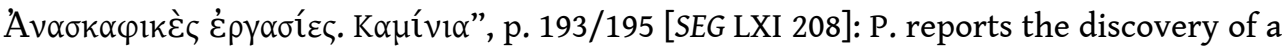
defixio in a grave at Kaminia (Piraeus).

94) J. PICCININI, “A Forgotten Votive Plaque from Dodona”, ZPE 187 (2013), p. 69-71 [BE 2014, 56]: The author draws attention to an inscribed bronze plaque from Dodona with a metrical dedication (4th cent.); this object, once in the collection of F. Trau, is now lost (M. DIETERLE, Dodona. Religionsgeschichtliche und historische Untersuchungen zur Entstehung und Entwicklung des Zeus-Heiligtums, Hildesheim, 2007, p. 97 f.; not in CEG).

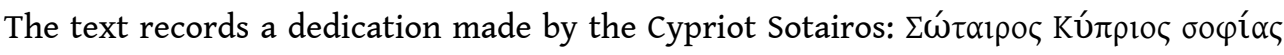

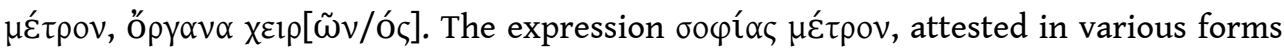
in connection with poetic compositions, suggests that Sotairos was a rhapsode; the tablet must have been attached to the dedicated object (a lyre or a kithara). Considering two other dedications made by rhapsodes in Dodona in the 5th and 4th/ 3rd cent. (SGDI 5786 and Collection Froehner 39), P. plausibly argues that there must have been rhapsodic contests at the Naia during this period.

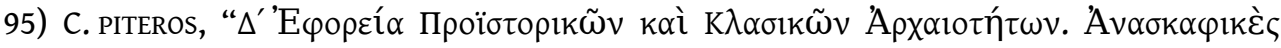

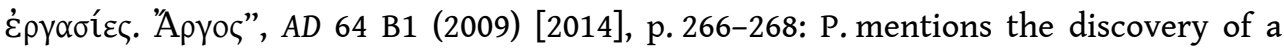
votive relief with a representation of Zeus holding the thunderbolt (Argos, 1st cent.).

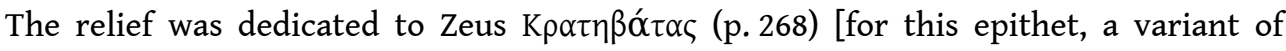

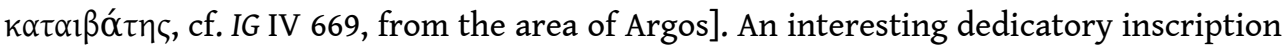
on the base of a statue of Vespasian, found in the agora of Argos, reports that the statue 


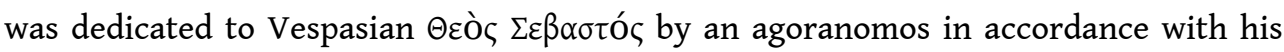
testament.

96) G. REGER, “A New Inventory from Mylasa in Karia”, in Stephanèphoros, p. 145-163: Ed. pr. of an inventory of silver cult vessels from Mylasa (early 2nd cent.). The inventory

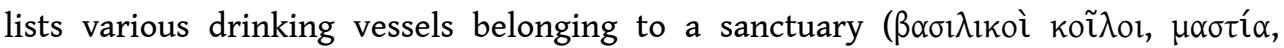

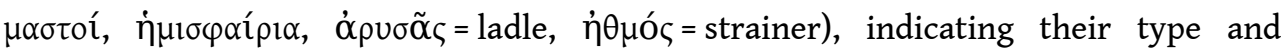

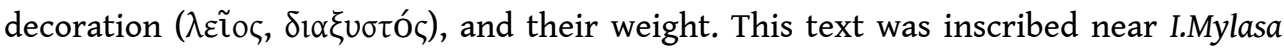
308 , in which $\dot{\eta} \rho \omega \sigma \tau \alpha$ í are mentioned. The vases may have been used in a hero cult

97) G.H. RENBERG, "Dream-Narratives and Unnarrated Dreams in Greek and Latin Dedicatory Inscriptions", in E. SCIOLI, C. WALDE (eds.), Sub imagine somni: Nighttime Phenomena in Greco-Roman Culture, Pisa, 2010, p. 33-61: This important contribution to the study of dreams is dedicated to descriptions of dreams in Greek and Latin inscriptions. More than 1300 dedications (5th cent. BCE-4th cent. CE) were explicitly made in response to a god-sent dream or a divine command given through an

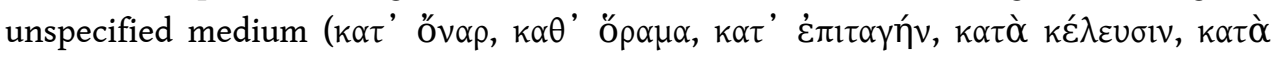

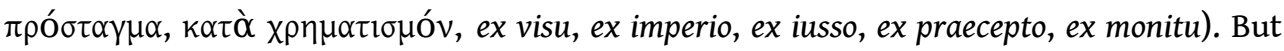
only very few among them specify that one or more gods had appeared in a dream - or (in one case) in a waking vision - and provide information on the dream: 1) ILAlg II. 1.482 (Cirta, Imperial period): A husband and wife made a dedication to Honos and Virtus viso moniti deae; cf. AE 1996, 1147 (visu dei monitus; Grinario); CIL VIII 25997 (ex viso

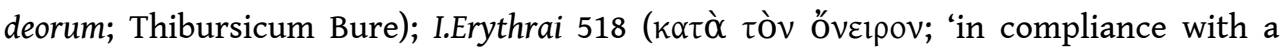
dream-figure'). 2) IG IV 21.127 (Epidauros, $224 \mathrm{CE}$ ): Asklepios appeared to a patient in

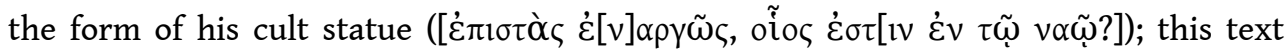
shows how artistic representations of gods influenced people's dreams (cf. Artemidoros, Onirocriticon 2.35; Longus, Daphnis et Chloe 2.23; Amm. Marc. 20.5.10). 3) EAM 15 (Aiane, late 2nd cent. CE): A man saw Plouton and his temple in his dream

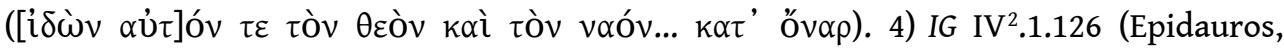
ca. $160 \mathrm{CE}$ ): Asklepios appeared in the dream of a man suffering from digestive problems and gave him the prescription for the cure. 5) Syll. ${ }^{3} 763$ (Kyzikos, 46 BCE): When a gallos of Kybele asked the goddess about the fate of his missing companion, the goddess revealed that the man had been captured but would be saved ( $\tau \tilde{\eta} \varsigma \quad \theta \varepsilon \tilde{\alpha} \varsigma$

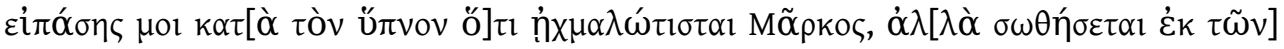

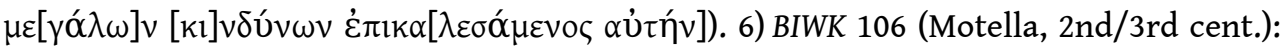
Apollo Lairbenos appeared in a sinner's dream and spoke to him (óveípors $\mu \mathrm{or}$

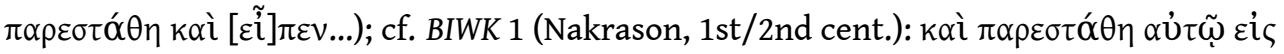

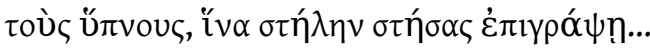

7) I.Priene 196 (late 4th cent.): Demeter, Kore, and the hero Naulochos appeared three times in the dream of Philios requesting the establishment of Naulochos' cult. 8) I.Knidos 131 (ca. 400-350): Hermes told a mother that her deceased daughter held an honored place in the underworld. 9) CIL VIII 2632 (Lambaesis, ca. 200 CE): Liber Pater appeared to an officer in a dream and instructed him (visus dicere somno) to restore a statue of the genius domus. 10) SEG LIII 454 (Akraiphia, early 3rd cent.): A dedicant asks

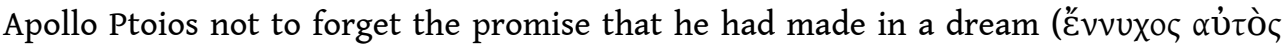

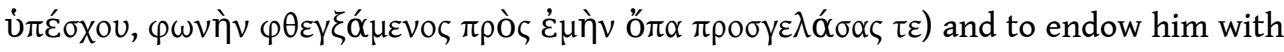
the gift of prophecy (cf. F.Delphes III.4.460: [Athena] $\dot{\varepsilon} v$ ü $\pi v \omega 1 . . . \quad \sigma \alpha \varphi \tilde{\eta}$ $\theta \tilde{\eta} \kappa \varepsilon v$

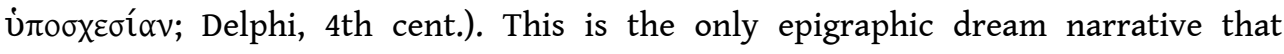
mentions a facial expression. 11) IGUR 184+add. (Rome, 2nd cent. CE): Pan cured a man 


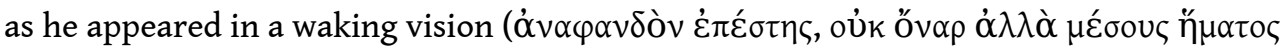

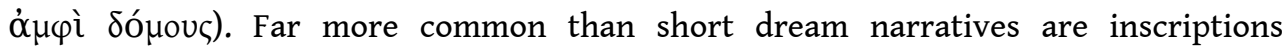
reporting that a dedication was made upon a divine command given in a dream (e.g. CIL III 11138; VI 401, 533; V 3321; AE 1932, 77; 1955, 156; IGBulg II 680; V 5220). But even short formulations sometimes allow us to reconstruct the dream experience: e.g. a woman reports in a grave inscription from Lydia (TAM V.1.661, Imperial period) that

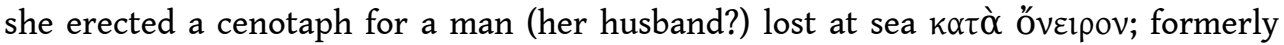
having refused to believe that he had died, she finally constructed a grave when the dream confirmed her worst fears.

98) M. RICL, "Trapezonai in the Sanctuary of Pluto and Kore at Acharaca", The Ancient West and East 12 (2013), p. 295-302 [BE 2014, 430]: An honorific decree from Nysa for a certain Clodia Cognita provides information about her donation to the sanctuary of Plouton (SEG LX 1130, 1st cent. CE) [discussed in EBGR 2010, 54]. R. analyzes the clause concerning the trapezonai and their activities in the sanctuary. They were not people who hired out tables for cultic purposes (as the eds. suggested), but entrepreneurs who leased cult tables from the city [the same proposal was already offered by P. HAMON, $B E$ 2011, 527 and in EBGR 2010, 54]. In R.'s interpretation, the trapezonai leased out cult tables for the display of votive offerings. When the offerings were sold at auction by the city, they received a percentage. The authorities of Nysa excluded the offerings made by Cognita and her relatives from this procedure and from the future profit of the

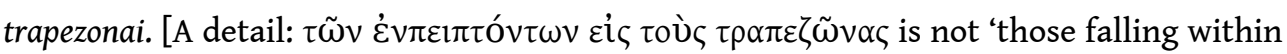
the province of the trapezonai' or 'falling within the responsibility of the trapezonai', but (in the context of income) 'the proceeds of the trapezonai', as correctly translated by the eds.; cf. P. HAMON, BE 2014, 430].

99) M. RICL, "New Inscriptions from the Kayster River (Küçük Menderes)", EA 46 (2013), p. 35-56 [BE 2014, 413, 425]: Ed. pr. of inscriptions from south Lydia. An honorific inscription from Bonitai, in the territory of Ephesos (10, 3rd cent. CE) was set up for a female gymnasiarchos and benefactor, who was the daughter of a neopoios and a former priestess of Artemis; it belongs to a small group of texts (I.Ephesos 3232, 3233, 3239, and 3239 A) with similar wording. It seems that in Bonitai the daughters of neopoioi served as priestesses in the same year as their fathers, inheriting this position from their mothers [this is not certain: that their mothers had also served as priestesses does not necessarily mean that the position was hereditary]. An inscribed architrave (19, 3rd cent. CE) mentions an already known Ephesian, L. Septimius Aurelius Achilleides, a member of the equestrian order who had served as agonothetes (I.Ephesos 743 and 845). Two brothers are addressed in their epitaph as

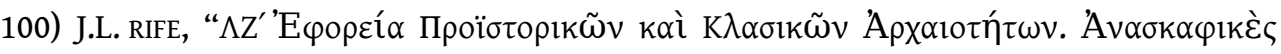

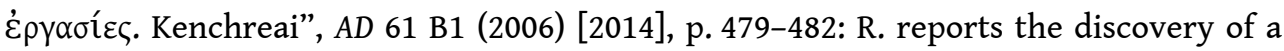
defixio at Kenchreai, near Corinth. According to C. Faraone, who is studying the text, it is a Greek prayer for justice against a thief of clothes. The text invokes chthonic deities and curses the culprit 'with the force of Lord Abrasax'.

101) D. RousSET, "Les inscriptions antiques de Phocide et de Doride", CRAI (2012), p. 1659-1689: In an overview of epigraphic research in Phokis and Doris, R. presents an inscribed bronze base of a lamp or an incense burner dedicated by the Diondai (a family group, a civic subdivision?) in the sanctuary of Athena in Antikyra: $\Delta$ iõv $\delta$ í $\mu$ '

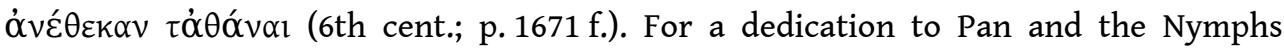
(1678 f.) see supra $\mathrm{n}^{\circ} 59$. 
102) F. SACCHI F. BONZANO, "L'ordine del tempio di Apollo a Hierapolis: prime acquisizioni ", in Hierapolis di Frigia V. Le attivitè delle campagne di scavo e restauro 2004-2006, Istanbul, 2012, p. 325-357: Ed. pr. of an inscribed column from the Great Baths of Hierapolis (p. 344-348). It is dedicated to Tiberius and the Demos by a local benefactor who had been honored by the city with the title 'son of the city' and who is designated as 'lover

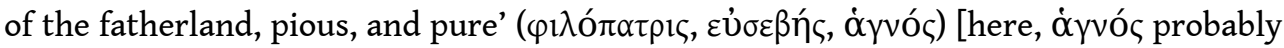
does not refer to religious purity but to moral purity and honesty].

103) A. SCHACHTER, F. MARCHAND, "Fresh Light on the Institutions and Religious Life of Thespiai", in N. PAPAZARKADAS, P. MARTZAVOU (eds.), Epigraphical Approaches to the PostClassical Polis, Oxford, 2012, p. 277-299 [BE 2013, 168]: Ed. pr. of inscriptions from Thespiai. 1)A dedication - possibly of a herm - was made by tax farmers (pentekostologoi), (4th cent.). 2) A dedication to Apollo Genetas and Artemis Eileithyia (3rd/2nd cent.) was made by a priestess at the end of her term in office. There is ample evidence for the cult of Artemis Eileithyia in Thespiai, but Apollo Genetas is attested for the first time (cf. Apollo Genetor in Delos: Aristotle fr. 489 ed. Rose). The epithet

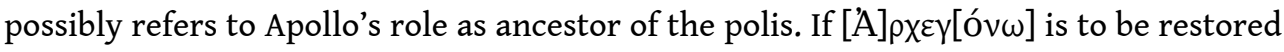
in I.Thespiai 53 (and not $[A] \rho \chi \varepsilon \gamma\left[\varepsilon \varepsilon^{\prime} \alpha o\right]$ ), Genetes may be a synonym of Archegonos. [More plausibly D. KNOEPFLER, BE 2013, 168, suggests interpreting the two deities as 'deux divinités protectrices de la famille'; but Genetas may also be a patron of family groups].

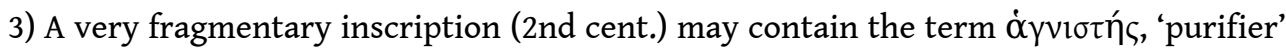

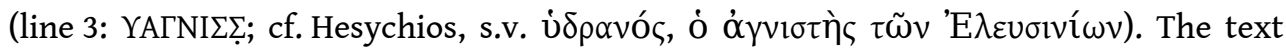

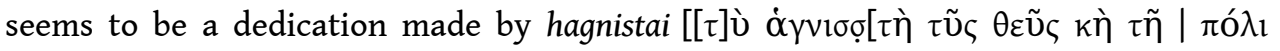

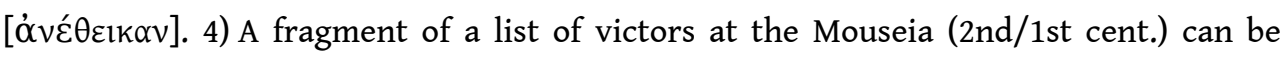
added to the rich dossier concerning this festival.

104) G.C.R. schmalz, Augustan and Julio-Claudian Athens. A New Epigraphy and Prosopography, Leiden, 2009: S. presents a survey of Athenian inscriptions that date to the reign of Augustus and the Julio-Claudian dynasty. The epigraphical catalogue (p. 9225) assembles 298 documents with brief comments on their significance for the history of Athens in this period. The texts include the decree concerning the restoration of Attic shrines and public properties $\left(2=I G \mathrm{II}^{2} 1035\right)$, texts commemorating the theoxenia of Plouton (45-46 = IG II ${ }^{2} 1935$ and 2464), numerous texts pertaining to the imperial cult (p.113-156), a dedication of pyloroi from the Acropolis (p.67-78), dedications by officials and priests (p. 85-89), associations (p. 90), and victors (p. 91101), dedications to gods (Amynos, Asklepios, Hygieia, Aion, Apollo, Demeter and Kore, p. 277-291), building inscriptions and dedications (p. 102-112), an agonistic catalogue commemorating ephebic victories $\left(79=I G \mathrm{II}^{2} 2328\right)$, honorific decrees and honorific inscriptions for cult officials (dadouchoi, hierophants, agonothetai, high priests, and priests; p. 162-181), and cult regulations. Among the latter I mention the consultation of the Delphic oracle by the Gephyraians concerning the bouzuges and priest of Zeus in the Palladion $\left(12=I G \mathrm{II}^{2}\right.$ 1096). The catalogue is followed by a prosopography (p. 229318) and a list of priests and priestesses during this period (p. 320-325).

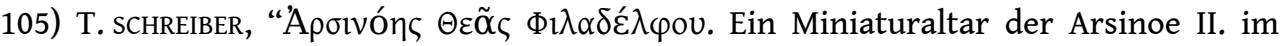
Archäologischen Museum der Westfälischen Wilhelms-Universität Münster", Boreas 34 (2011), p. 187-201 [BE 2014, 60]: S. republishes a miniature altar for the cult of Arsinoe II, acquired by E. Rubensohn in the early 20th cent. in Egypt and now in the archaeological collection of the University of Münster. Although the text has been known since 1905 (SB 434), the object on which it was engraved has never been 
discussed until now. The miniature altar belongs to a group of numerous similar objects attested in several places in the eastern Mediterranean, especially in Cyprus, and was probably used for the private cult of Arsinoe. An unusual feature of the inscription is that Arsinoe is designated thea [see also supra ${ }^{\circ} 41$ ].

106) D. scHÜRR, "Beobachtungen zu den Zwölfgötter-Reliefs in Lykien", Adalya 16 (2013), p. 213-222: S. gives an overview of the reliefs of the Lykian 'Twelve Gods'. These gods were jointly worshipped with Artemis Kynegetis and their father, probably Zeus. A main sanctuary must have existed in or near Phellos.

107) P. SIEWERT, H. TAEUBER, Neue Inschriften von Olympia. Die ab 1896 veröffentlichten Texte, Vienna, 2013 [BE 2014, 176]: This collection of 368 inscriptions assembles the texts that were published after the publication of $I v O$ in 1896. It will provide an important service until the projected volume of the IG with the inscriptions of Olympia appears. Naturally, most texts are directly or indirectly related to religious matters. I only mention the main categories and highlight a few important inscriptions. Cult and other regulations: A regulation concerning the contests of the Olympic games (1-3, 6th cent.); a document awards privileges to Greeks from areas beyond the mainland (4, ca. 500); a treaty between the Akarnanians and Anaktorion concerns the sanctuary at Aktion (13 = LSCG Suppl. 45, 216 BCE). Cult personnel: There are lists of cult officials of Zeus' sanctuary (16-20; theokoloi, spondophoroi, manteis, exegetes, spondaulai, epispsondorchestai, alytarches, and alytai). Dedications: There are numerous dedications to Zeus Olympios, both by communities (33-34, 201-207) and private individuals (35-40, 42-43, 51-52, 56,

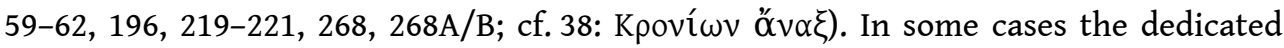
objects are honorific statues to Zeus (552: a former theokolos; 56: an allytarchos; 59: Herodes Atticus, priest of Dionysos; 60 and 61: a high priest of the imperial cult; 62: a high priest of Asia). Dedications are also addressed to Artemis (48: an altar), Demeter (41), Demeter, Kore, and Basileus, i.e. Plouton (43A), Pelops (268C), and Herakles (191; weapons). Dedications of weapons are very common (120-191); in most cases they are explicitly addressed to Zeus Olympios $(121,123,124,131-140,142,144-149,152-153$, 156-160, 162, 164-168, 171-175, 177-180, 182-190) or mention his sanctuary $(169,170$ :

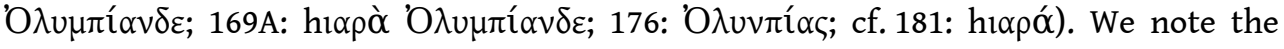

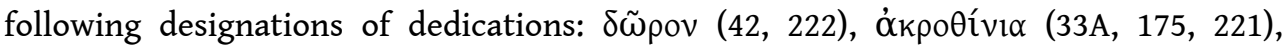
$\lambda \alpha \varphi_{\varphi v \rho \alpha}(160)$. A text refers to the prayer made during the dedication: $\left[\lambda_{1} \sigma \sigma\right] \operatorname{có}_{\mu \varepsilon v o ́} \varsigma \sigma \varepsilon$,

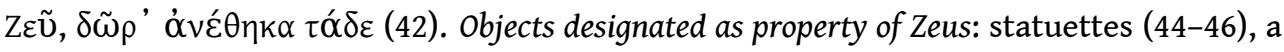
bronze olive leaf (47), cauldrons $(209,211,213)$, a basin (214), scrapers (215-216), an obolos (210), a plate (267: i $\alpha \rho o ́ v)$. A knife was the sacred property of Pan (212). There are also tiles (73), weights (228-245), and ballots (247-248) inscribed with the name of Zeus (Olympios). Olympic contest: A list of Olympic victors attests the survival of the Olympic games until Late Antiquiy (10, ca. $385 \mathrm{CE}$ ); cf. lists of victors (21-32). An interesting grave epigram for the boxer Agathos Daimon, known as 'the Camel', mentions that he was killed during a fight at the age of 35 . Before the fight he had

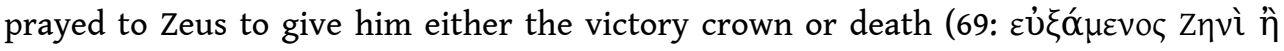

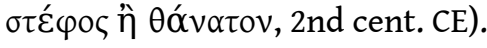

108) I. šopova, "On the epitaph from Malko Tărnovo", Thracia 20 (2012), p. 327-330 [in Bulgarian; BE 2014, 302]: The author discusses an interesting grave epigram from Malko Tărnovo (IGBulg III.2.1862 = V 5656, early 3rd cent.) dedicated to Chreste, member and

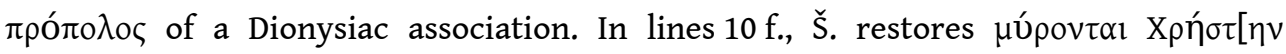

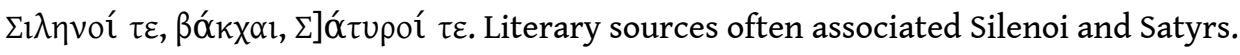




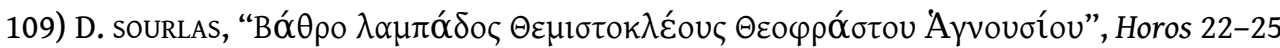
(2010-2013), p. 169-174: Ed. pr. of a dedication from a gymnasion in Athens. A man dedicated a bronze torch, after he had served as lampadarchos (53/52).

110) R.S. STROUD, Corinth XVIII.6. The Sanctuary of Demeter and Kore: The Inscriptions, Princeton, 2013 [BE 2014, 173]: Corpus of the inscriptions on stone (1-10), bone (13), pottery (15-117), and metal (11-12) from the sanctuary of Demeter and Kore in Corinth; inedita are marked with an asterisk. Four are boundary stones that probably marked the sacred precinct $(2-5$; 5 th-4th cent.). Many inscriptions can be recognized as dedications to Demeter (Archaic period-ca. $200 \mathrm{CE}$ ), even when the name of the goddess is not preserved $\left(1,7^{*}-9^{*} ?, 10,11,15-21,40,41-50 ; 11\right.$ is a bull statuette; $49^{*}-50^{*}$

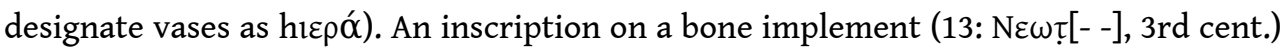
may be a reference to the $N \varepsilon \omega \tau \varepsilon \dot{\varepsilon} \alpha$, who is mentioned in a mosaic (14). The mosaic inscription (ca. $200 \mathrm{CE}$ ) reports that a neokoros sponsored a mosaic floor when Chara was the priestess of Neotera. S. identifies Neotera with Kore [for a different view see B.S. SPAETH, "Imperial Cult in Roman Corinth: A Response to Karl Galinsky's 'The Cult of the Roman Emperor: Uniter or Divider?"', in J. BRODD, J.L. REED (eds.), Rome and Religion: a Cross-disciplinary Dialogue on the Imperial Cult, Atlanta, 2011, p. 75-77, who assumes that

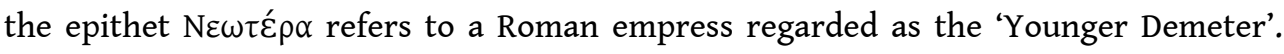
However, the title of a priestess of the imperial cult could never have been rendered as

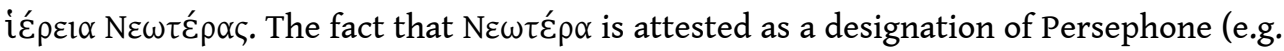
IG II ${ }^{2} 1672$ lines 300-302) supports Stroud's interpretation]. An inscribed vase (74*, Classical period) possibly names a hero: [n̆] possibly does not designate ownership or dedication, but the use of the vase for

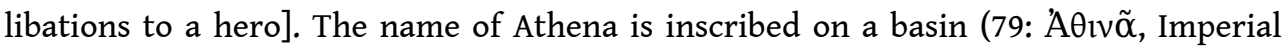
period). The inscriptions on early Hellenistic clay pinakes (98-117) are puzzling. In some cases they can be identified as divine names in the genitive (98: $\Delta$ lovv́бov; 99:

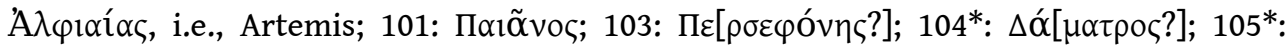

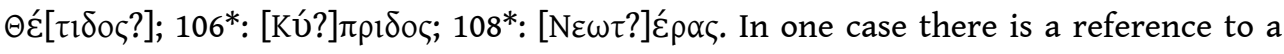

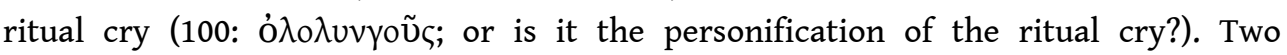

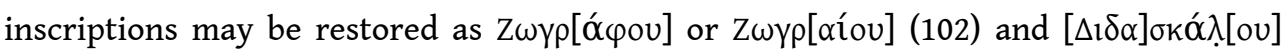
$\left(115^{*}\right)$. The meaning of these pinakes is elusive. Were they counters in a game in which the characters bore divine names? Or were they used in a ritual, in which boys or men chanted the paian, while girls and women summoned Dionysos with a ritual cry? [The possible reference to a chorus teacher (115) and a painter (102; zographos is the designation of the painter of theatrical stages) make the latter hypothesis very attractive]. The most interesting group of inscriptions is comprised of 18 lead tablets with curses (118-135, Imperial period), one in Latin (135, 4th cent. CE). The curses

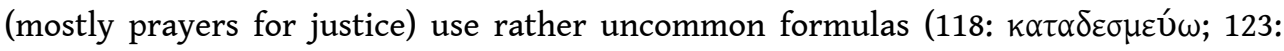

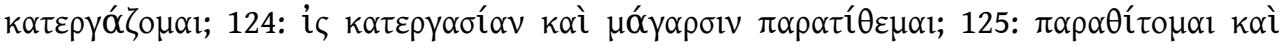

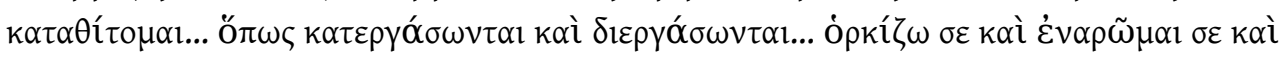

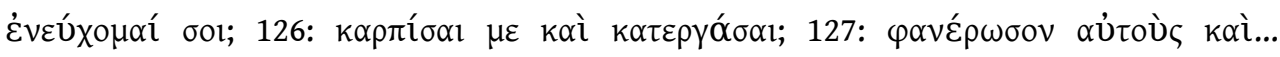

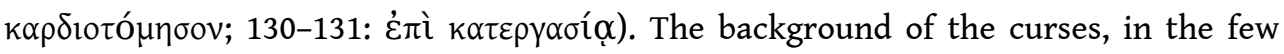

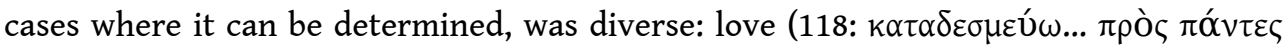

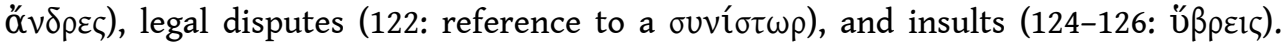

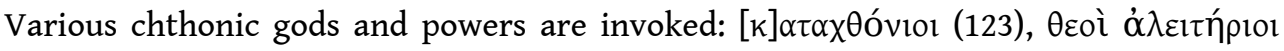

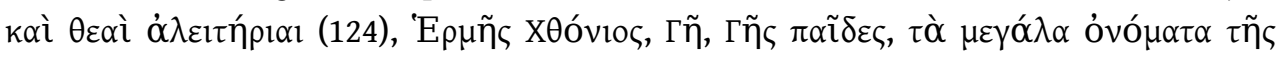

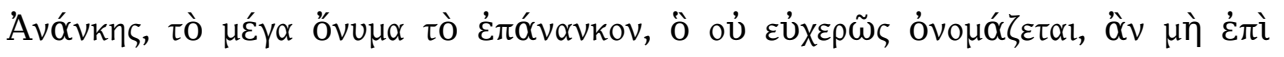




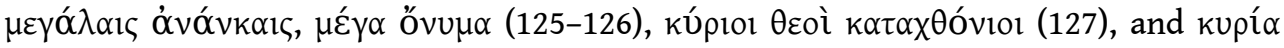

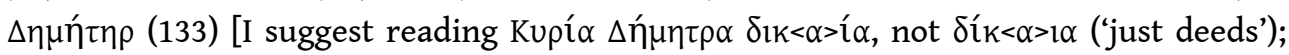
Demeter is invoked as a just goddess in a prayer for justice]. Magical names and words do not appear very often (125-126; cf. the $\mu \alpha \sigma k \varepsilon \lambda \lambda_{1}$ spell in $\left.n^{0} 119\right)$. In several instances the curses are directed against body parts $(118,122,125,126)$. S. provides an extensive commentary on the curses and the practice of magic in Roman Corinth.

111) D. sUMMA, "Ein neuer Kitharöde aus Kos (IG XII.4, 2, 1166)", ZPE 184 (2013), p. 175182: Ed. pr. of a dedication made by Halasarna to Apollo, as an expression of gratitude for the victories of the local kitharode Iason (Halasarna, reign of Claudius) [this text was also included in IG XII.4.1166, which appeared in 2012]. Iason won more than 70 trieteric and pentaeteric events in numerous contests, the most important of which are mentioned by name: Aktia, Klaudeia in Rhodes, Isthmia (twice), Nemea (twice), Lykaia, Aspis in Argos (twice), the contests organized by the Koina of Asia, Thessaly (three times), Macedonia (three times), Ionia (twice), isolympian contests in Athens (four times in a row), and a contest mentioned in a lacuna.

112) K. TAKEUCHI, "Ten Notes on Inscriptions from the Attic Demes", Horos 22-25 (20102013), p. 85-106: T. supplies improved readings of ten Attic inscriptions. We present the most important ones. The sacrificial calendar of Erchia (SEG XXI 541, ca.375-350) mentions a sacrifice to take place in Aulon (A line 20), according to T.'s reading (not in Pylon; p. 90 f.). The sacrificial regulation from Paiania (IG I3 250, ca. 450-430) possibly provides for the zakoroi to leave behind a cup or cups of soup and porridge for Hekate

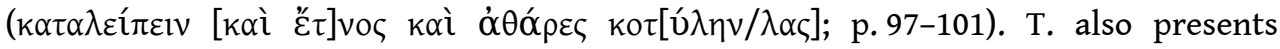
improved editions of a dedication to Dionysos and Apollo from Ikarion (IG I $\mathrm{I}^{3} 1015$, ca. 525; p. 94-96).

113) B. TAKMER, M. OKTAN, "Parerga zum Stadiasmus Patarensis (11): Die lykische Stadt Neisa”, Gephyra 10 (2013), p. 50-93: Ed. pr. of inscriptions found during a survey in central Lykia, in the area of Neisa. Two inscriptions provide evidence for the imperial cult. $\mathrm{N}^{\circ} 1$ is a block [part of an altar?] inscribed with the name of Augustus in the genitive. $\mathrm{N}^{\circ} 4$ is an honorary inscription for Diogenes, who had served as priest of the Augusti (mid-2nd cent. CE). $\mathrm{N}^{\circ} 5$ honors Dionysios, high priest of the imperial cult in Lykia (early 3rd cent. CE). $\mathrm{N}^{\circ} 8$ honors Aristonoe, also known as 'Lykia', who served as high priestess of the civic imperial cult together with her husband (cf. $n^{\circ} 6$, which honors a priestess or high priestess; early 3rd cent. CE).

114) C. TANRIVER, Mysia'dan yeni epigrafik buluntular, Izmir, 2013 [BE 2014, 397]: T. presents 57 new inscriptions, the results of epigraphic research in Mysia. If not otherwise stated, the texts date to the Imperial period. Bigadiç-Hisarköy: Dedication to

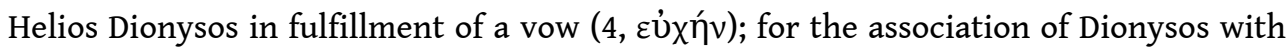
Helios cf. MACROBIUS, Saturnalia I, 18, 18, who quotes the Orphic verse "H $\lambda_{10 \zeta}$ ôv

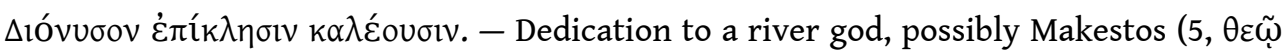

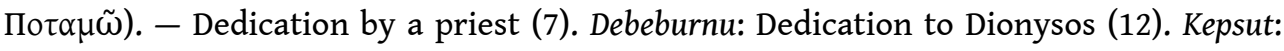
Dedication to Paianios Theos (22), possibly Apollo or Asklepios, rather than Dionysos or Zeus. Balikesir (and its area): Dedication of a statue of Poseidon Asphaleios to Zeus Pandemos (25); the dedication was made by a husband and his wife for the well-being of

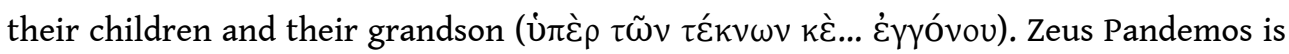
attested in Hadrianeia (I.Hadrianoi 85-86, 125-128; cf. the festival Pandemeia); the cult of Poseidon Asphaleios was widely diffused in the Greek world [for an association of Zeus and Poseidon Asphaleios see I.Tralleis 1]. Attea: An important text (34, late 
Hellenistic/early Imperial period) reports that the gerousia of Attea, along with the Greek and Roman inhabitants, dedicated an altar for the cult of a certain Menandros, in

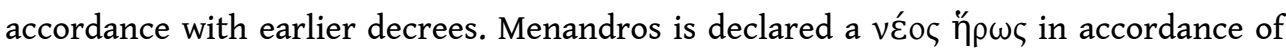
his father's dreams and visions (

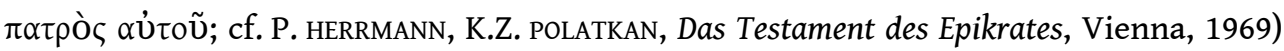
['by means of the ceremonies (consequent on) the dreams and visions of his father', is the translation of C.P. JONES, “A 'New Hero' at Attea (Mysia)", ZPE 192 (2014), p. 156-158

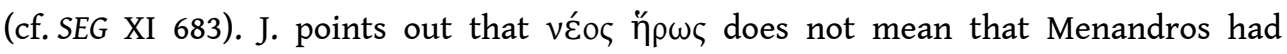
recently died; it is a reference to the young man's heroization. For such cases of heroization see C.P. JONES, New Heroes in Antiquity, Cambridge MA, 2010, p. 48 f.]. Savaştepe: The most interesting of this volume is a long dedication made by the priest

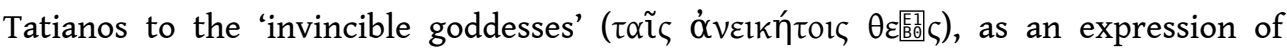

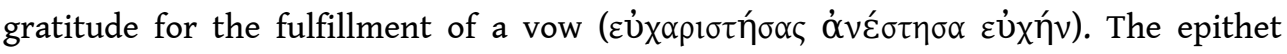

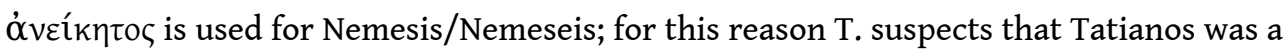
gladiator or soldier. [The text requires a detailed discussion that is not possible here; however, some of its essentials are offered in the following. Tatianos reports that a divine command was given to him by the goddesses, possibly in his dream (lines 4/5: ôv

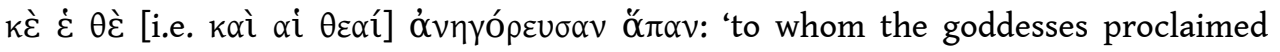
everything'). After explaining that he had constructed everything following this

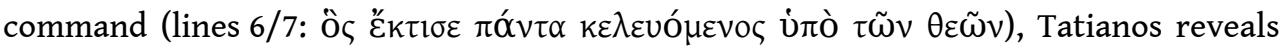
the nature of his cult foundation: he had introduced the cult of 'the all-embracing

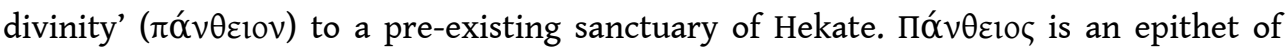
Zeus and Athena in Kyrene (LSCG Suppl. 116), but in the Imperial period חóv $\theta \varepsilon 10 v$, an acclamatory epithet that generally refers to divine power without revealing the name of the divinity, is attested in Epidauros (IG IV $2.1 .549-550$ ), Ephesos (I.Ephesos 819-821,

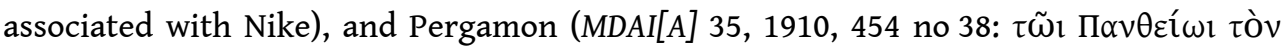
$\beta \omega \mu o ́ v$ ); see also supra $\mathrm{n}^{\circ} 47$ (but there probably in the meaning 'shrine of all the gods'). In Epidauros, a priest dedicated an altar to Pantheion $\kappa \alpha \tau$ ' óv $\alpha \rho$ (IG IV ${ }^{2} .1 .550$ ), exactly like Tatianos. In Tatianos' case, the Pantheion is probably identified with the anonymous invincible goddesses (Nemeseis?). I reproduce the text using standard spelling and

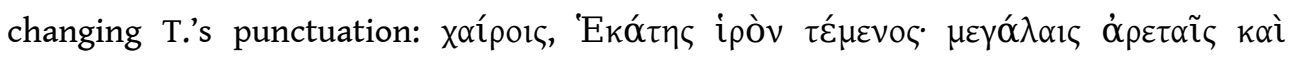

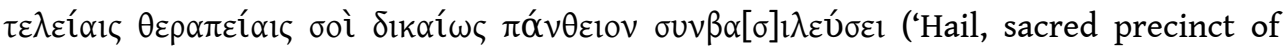
Hekate. The Pantheion will justly rule jointly with you, with great manifestations of its power and with perfect/complete religious service'. These words may be a quotation of the command received by Tatianos. The text continues with a warning against those

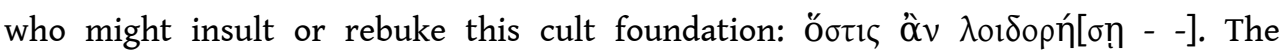
emphasis given by Tatianos on the fact that he acted upon divine command indicates his anxiety that his innovation might meet with opposition]. - An altar of Zeus (38, Hellenistic). - Dedication to Dionysos Kathegemon and his synnaoi (36). - Dedication to

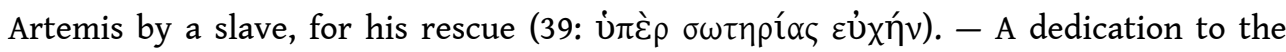
Horai and the Charites by the orator Aelius Aristides (40). - A Jewish synagogue made a dedication to the 'providence' ( $\pi$ povoí $\alpha$ ) of Hadrian (41) [an interesting testimony for the indirect participation of Jews in the imperial cult, either before the Jewish revolt or as an expression of loyalty after the Jewish war]. - Dedication of a statue of an anonymous god (43). - Dedication to Zeus (44).

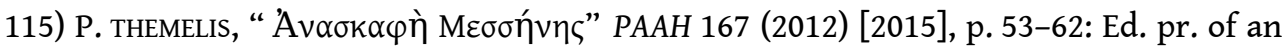

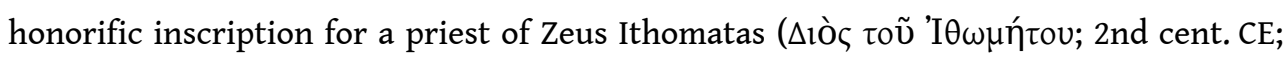


p. 59). A fragmentary delimitation between Messene and another city mentions a sanctuary of Demeter as a point of orientation (2nd cent.; p. 61).

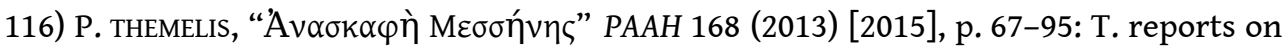
numerous new epigraphic finds in Messene. Two stelae contain honorific decrees for the quaestor and propraetor P. Cornelius Scipio (ca. $4 \mathrm{CE}$ ). According to the first decree, Scipio was honored with a painted portrait; his image was to be crowned by an

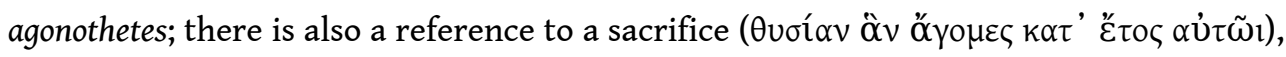
the wearing of wreaths, and a sacrifice for the health of Augustus. [An earlier decree for the same Scipio (SEG XXIII 206) permits a better understanding of the new text. The

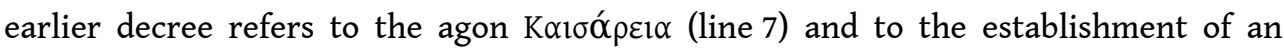
annual sacrifice for Caius Caesar (lines 17-21). The similarity between the earlier decree and the first lines of the new decree suggest that the new text refers to Caius

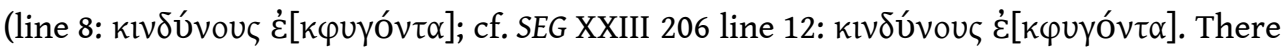

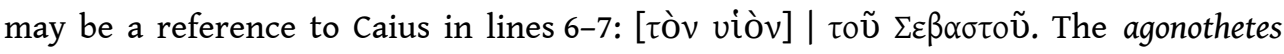
(line 17) is the one for the Kaisareia]. The second decree mentions extra-ordinary honors for Scipio. His statue was erected next to that of Augustus. A festival in his

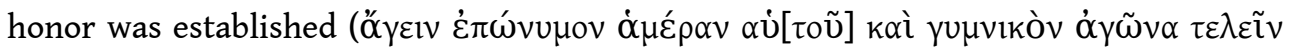

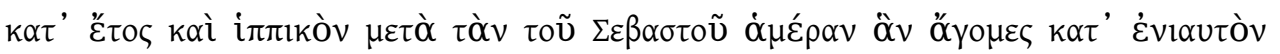

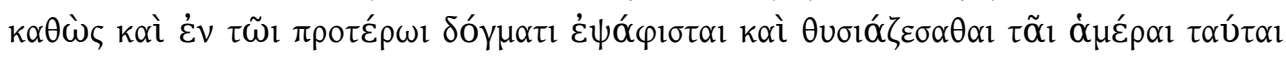

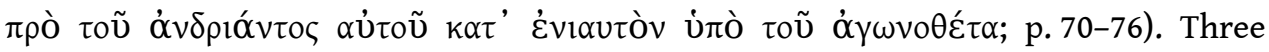
Hellenistic agonistic inscriptions mention victories (p. 82 f.) of two wrestlers and a pankratiast. The first wrestler won as a boy at the Lykaia, Antigoneia, and Naia; the second wrestler won as a boy at the Eleutheria, Lykaia, and Eleusinia, and as a man at the Heraia, Basileia, Naia, Antogoneia, Isthmia, Nemea, Pythia, and Olympia; the third man won victories in an unknown disciplin at the Antigoneia, Eleutheria and other festivals, and in pankration at the Naia, Soteria, and Aleaia. A fragmentary text (account?) mentions dedications made in the sanctuary of Dionysos. A(86); a second text concernimg building works contains references to the temples of Dionysos and Aphrodite (3rd cent, p. 87). A fragmentary delimitation between Messene and another city mentions a sanctuary of Demeter as a point of orientation (2nd cent.; p. 61). There are also a dedication to Athena (p. 84), a fragment that mentions the Megaloi Theoi (90,

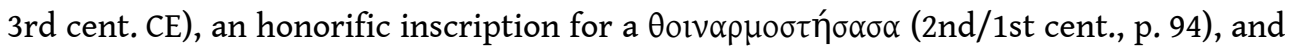

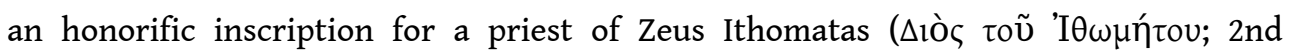
cent. CE; p. 59).

117) G. THÉRIAUlt, "Culte des évergètes (magistrats) romains et agônes en Asie Mineure", Stephanèphoros, p. 377-388: T. reviews the evidence for contests organized in Asia Minor to honor Roman magistrates in the last century of the Republic and the first decades of the Principate. Such agones also existed in Greece (Titeia in Argos, an agon in Eretria for Lucius Mummius, the Sulleia and Antonieia in Athens, and an equestrian agon in honor of Marcus Annius in Lete) and Sicily (Marcellia in Syracuse). In the province of Asia, the Moukieia, an agon for Q. Mucius Scaevola (governor in 98/97 or 94/93), was added to the pre-existing agon Soteria (OGIS 438-439); it probably took place in the major cities of the province. The Euergesia (IGR IV 291), likely celebrated in several cities of Asia, was not exclusively dedicated to Roman benefactors. Contests were also established for L. Valerius Flaccus (governor in the 90s) in Tralleis, L. Licinius Lucullus in Kyzikos (ca. 73), Paullus Fabius Maximus (governor in 10/9 or 7/6) in Alexandreia/ Troas (Smintheia Pauleia: I.Alexandreia/Troas 52-53), C. Marcius Censorinus (governor in 
2/3) in Mylasa (I.Mylasa 341), and Cn. Vergilius Capito, Claudius' procurator in Egypt, in Miletos (I.Didyma 278).

118) P. THONEMANN, Monumenta Asiae Minoris Antiqua. vol. XI. Monuments from Phrygia and Lykaonia Recorded by M.H. Ballance, W.M. Calder, A.S. Hall, and R.D. Barnett, London, 2013: This volume assembles 387 monuments from Phrygia and Lykaonia, mostly inscribed (new texts are marked with an asterisk; the texts date to the Imperial period, unless otherwise stated). Apollonia by Pisidia [cf. EBGR 2012, 102]: An honorific inscription for a

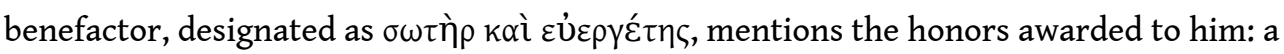

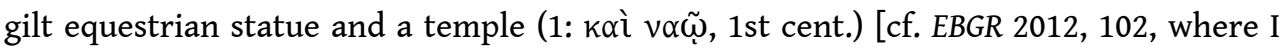
suggest a slightly earlier date; $T$. assumes that the anonymous benefactor received 'lifetime cult honours', like e.g. Diodoros Pasparos; but there is nothing in the text that suggests that the honorand was alive]. Another honorific inscription was erected for a man who provided wild-beast shows and gladiatorial combats 'in all contests' ( $\dot{\varepsilon} v \pi \tilde{\alpha} \sigma l$

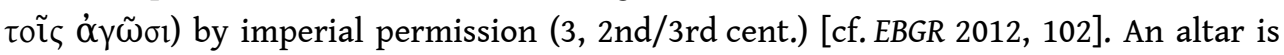
dedicated to Zeus (10, Hellenistic or Imperial period), an uninscribed altar possibly to Attis (12). The iconography of a stele (crescent moon) suggests that it was dedicated to Mes (11). Eumeneia: An honorific inscription for a hieronikes $26^{*}, 2 \mathrm{nd} / 3 \mathrm{rd}$ cent.). Dedications to: Apollo Propylaios, decorated with a double-axe and a snake $\left(30^{*}\right)$ and Theos Hypsistos $\left(31^{*}\right)$ [or Zeus Hypsistos]. A bilingual funerary inscription set up by a

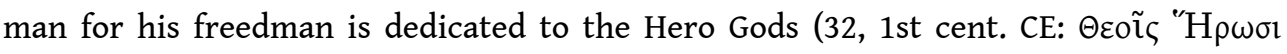
iєpó[v], [D]eis Manibu[s] sacrum). Sebaste: Dionysios dedicated an altar to Zeus and 'the

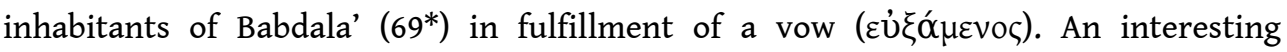
anatomical votive with a representation of a leg in relief explains: 'I, Aurelius Attalos, having been saved from a great illness, thank Mother Leto and the presiding Nemeseis

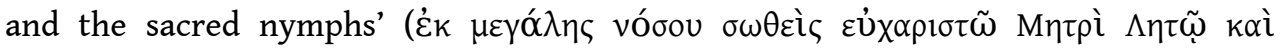

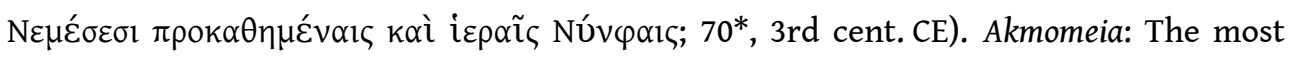
interesting text is a dedication made by two men designated as kouretes; they founded a sanctuary at their own expense $(109,2$ nd cent. CE). This is the first evidence for of a board of kouretes in Akmoneia. The cult of the Kouretes in Akmoneia, possibly connected with a tradition about Zeus' birth, is attested on coins. The women of Akmoneia, Greek and Roman, honored a high priestess (99, 6/7 CE) [cf. EBGR 2012, 188).

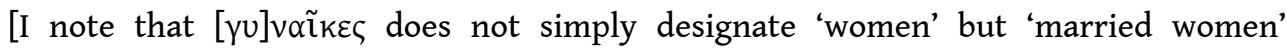
('wives'), as. T. more accurately translated in the ed.pr. (JHS 100, 2010, p. 165 and 175; cf. EBGR 2012, 188). It should also be noted that there is an exact parallel for an assembly of women issuing a decree in honor of a woman. It is an honorific inscription

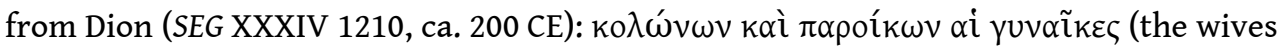
of the Roman colonists and the Greek inhabitants of Dion). Such groups of married women most likely assembled and issued decrees on the occasion of a festival, probably one exclusively attended by married women (such as the Thesmophoria). Such decrees do not necessarily imply a corporate organization]. The council and the people honored C. Claudius Egnatius Vigellius Valerius Ulpius Antonius Pollio Tertullianus, descendant

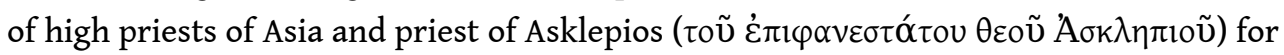
life, and agonothetes of the Great Asklepieia (101*, ca.150-200 CE). A building was dedicated to the Theoi Sebastoi $\left(107^{*}\right)$. An association ( $\left.\sigma u \mu \beta i ́ \omega \sigma \iota \varsigma\right)$ dedicated an altar to Zeus Alsenos Patrios Megas $(110,215 / 6 \mathrm{CE})$, asking him to protect the village ( $\varepsilon$ ì $\lambda \varepsilon \omega \varsigma$ $\tau \tilde{n}$

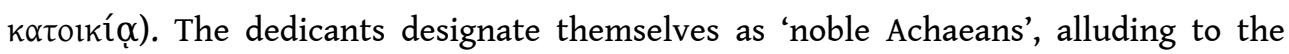

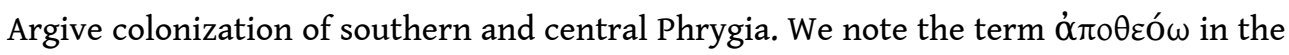


meaning 'to bury' $\left(126^{*}, 2 \mathrm{nd} / 3 \mathrm{rd}\right.$ cent.). An interesting grave inscription $\left(120^{*}\right)$ was set up by Alexandros, a benefactor, who had served inter alia as panegyriarches and rhapsodos[this is one of the rare attestations of rhapsodes in the Imperial period; see EBGR 2010, 61 and 206].

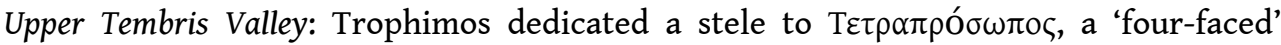
mother goddess (cf. MAMA V 101; SEG XIV 782), in accordance with her command ( $\dot{\omega} \varsigma$

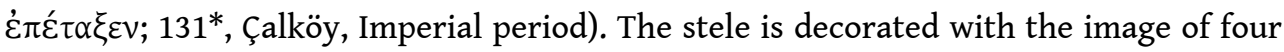
female figures (cf. MAMA VI 245, a dedication to Meter Theon Kasmine) and a mounted figure, probably Mes. One of the most interesting texts is the funerary epigram for

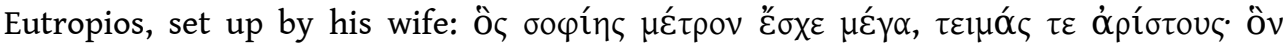

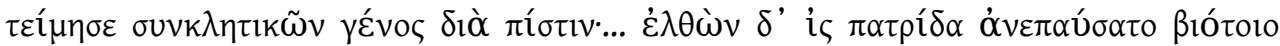

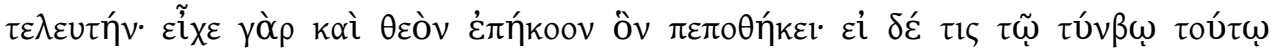

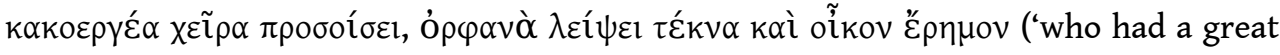
measure of wisdom, and whom a senatorial family honoured with the highest honours on account of his trustworthiness... on his return to his homeland, he found rest at the end of life, for he had a listening God whom he yearned for' [detailed discussion of this epigram as a possibly crypto-Christian text by É. CHIRICAT, "The 'Crypto-Christian' Inscriptions of Phrygia", in P. THONEMANN (ed.), Roman Phrygia: Culture and Society,

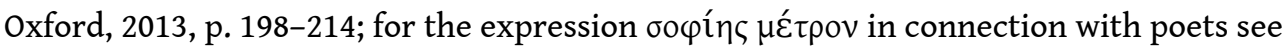

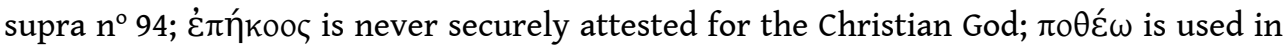
both pagan and Christian contexts; e.g. IG II ${ }^{2} 4514: \mu \alpha$ ó $\alpha \rho \tilde{\omega} \pi \varepsilon \pi \circ \eta \eta \mu \varepsilon ́ v \varepsilon$ (for Asklepios). Cf. É. BERNAND, Inscriptions métriques de l'Égypte gréco-romaine, Paris, 1969, $\mathrm{n}^{\circ} 129$ :

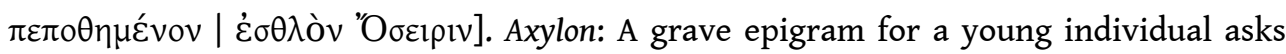

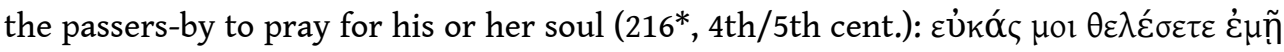

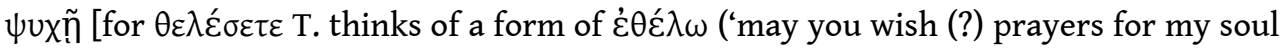

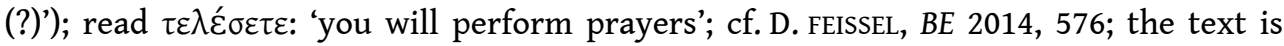

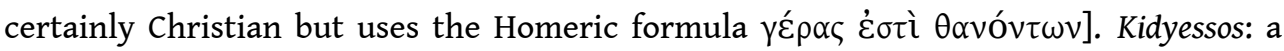

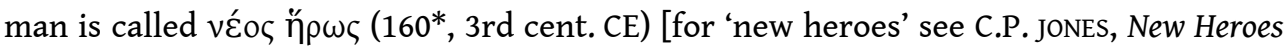
in Antiquity. From Achilles to Antinoos, Cambridge MA, 2010)]. Kinna: Dedications to Zeus

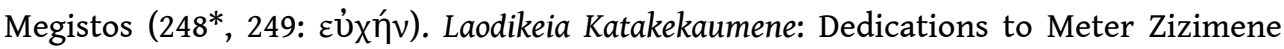
(255, 1st/2nd cent.) and Meter Amlasenzene (256*, 2nd/3rd cent.; घủxúv).

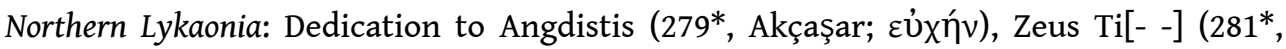

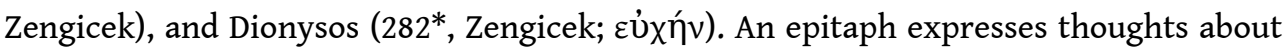

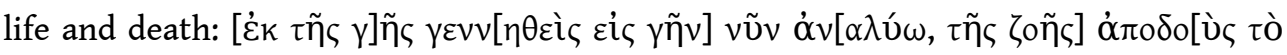

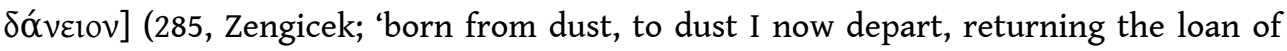

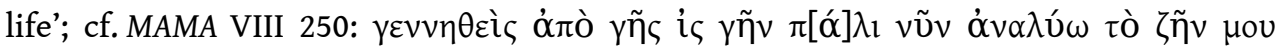

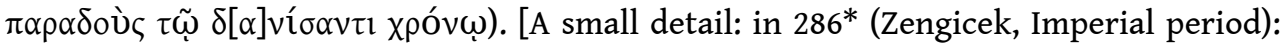

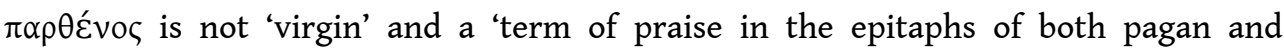
Christian women' but a reference to the age-class of the deceased girl; on parthenos as designation of an age-class see A. CHANIOTIS, "The Age of a Parthenos. A New Inscription from Aphrodisias", in B. TEKMER et alii (eds.), Vir doctus Anatolicus. Studies in Memory of Sençer Sahin, Istanbul, 2016, p. 200-205]. Konya: Dedication to Zeus Salarameus (297) and

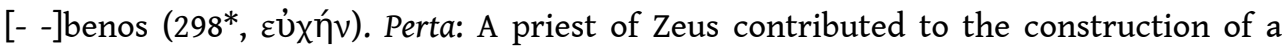

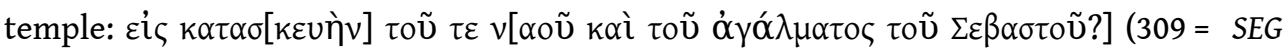

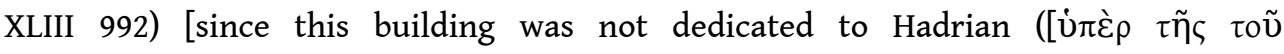

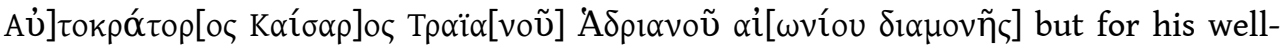


being, it is unlikely that it was a temple of the imperial cult; $\Sigma \varepsilon \beta \alpha \sigma \tau o \tilde{v}$, which cannot be

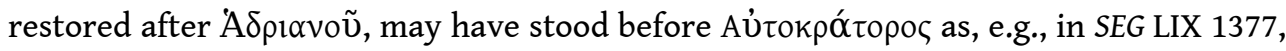
LX 349]. A dedication was made by a priest and his parents to Zeus Stratios Megistos

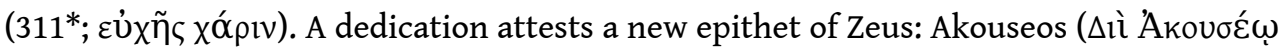

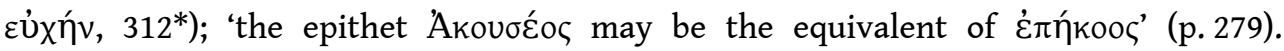

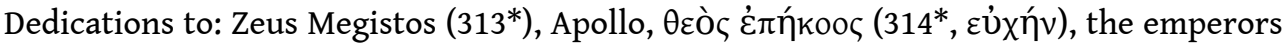

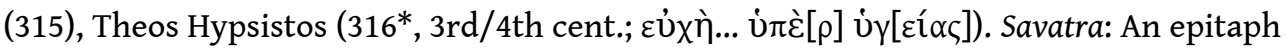
for a priestess and twice high priestess of the imperial cult $\left(345^{*}, 1\right.$ st/2nd cent.;

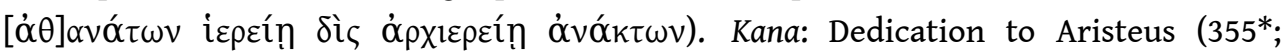

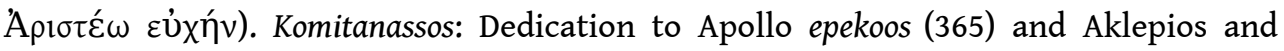

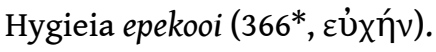

Inscriptions from various sites attest common and unusual formulae of funerary imprecations (if not otherwise stated, all texts date to the third cent. CE); in most cases, except for the imprecations that invoke Mes, it is difficult to determine if they are pagan, Montanist, Christian, or Jewish; I use standard Greek spelling for these texts:

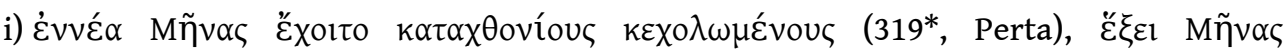

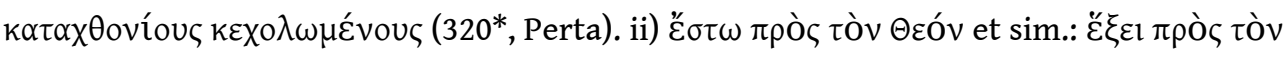

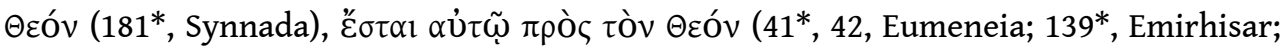

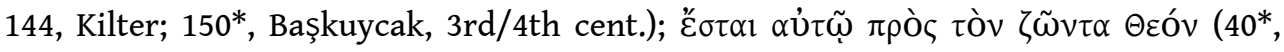

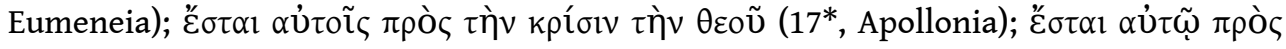

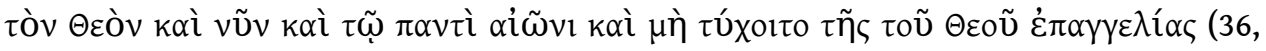

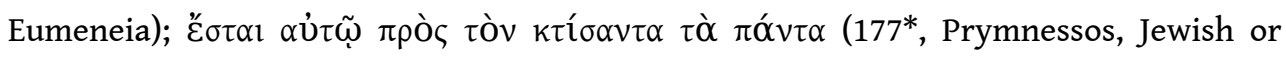

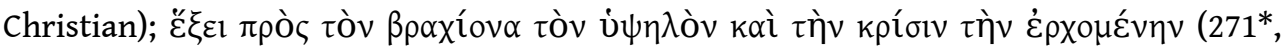

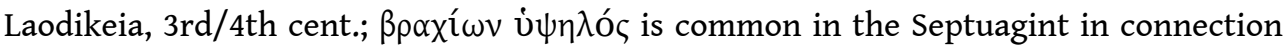

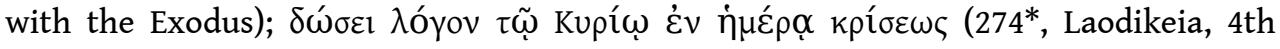

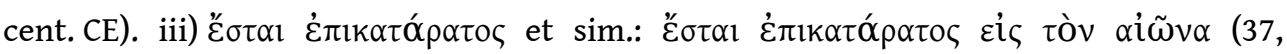

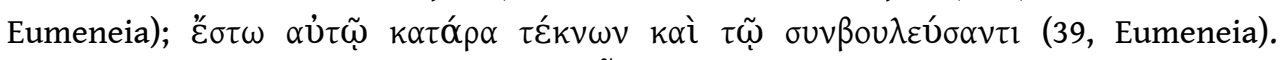

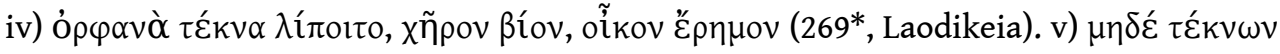

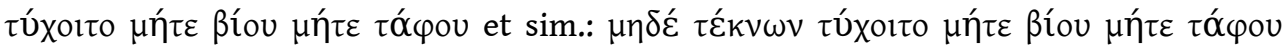

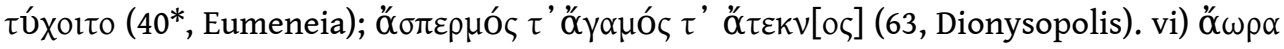

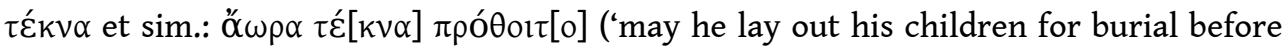

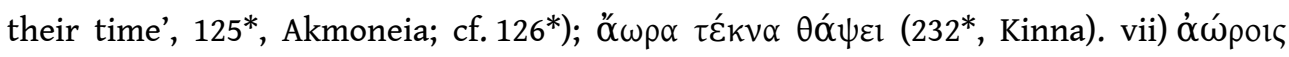

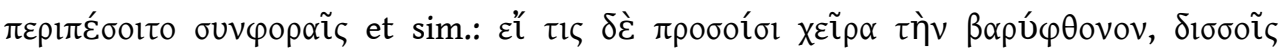
$\dot{\alpha} \omega$ poıৎ $\pi \varepsilon \rho \imath \pi \varepsilon ́ \sigma o \imath \tau o ~ \sigma u v \varphi о \rho \alpha i ̃ \varsigma ~\left(141^{*}\right.$, Karasandikh; 'if anyone lays a hand with heavy envy, may he fall victim to twofold untimely misfortunes'). viii) Unusual formulae: $\varepsilon$ l'

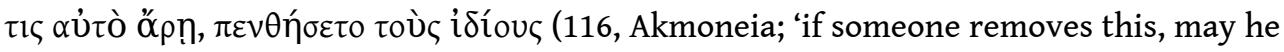

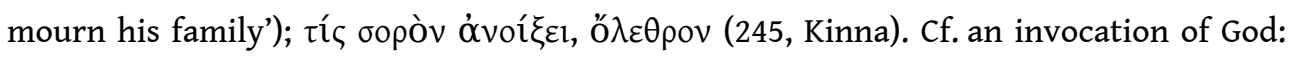

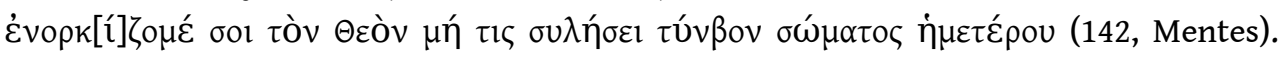
[For some critical remarks on individual texts see the review by C.P. JONES, JRA 27 (2014), p. 837-840].

119) A. TIRPAN, Z. GIDER, "Lagina ve Börükçü 2009 Yili Çalişmalari”, KST 32.2 (2011), p. 374-395: The authors report on new finds in Lagina (p. 379). An inscribed fragment of a lintel mentions an $\dot{\alpha} \rho x ı v \varepsilon \omega$ Kópoc. Fragments of vases are inscribed with the name of Hekate in the genitive.

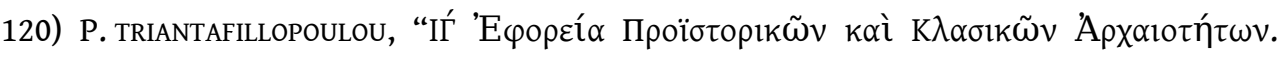

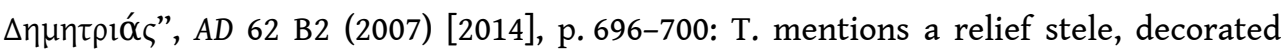


with an ear, dedicated to Meter Theon (Demetrias, Imperial period) [cf. EBGR 2012, 189. On the ph., after the partly preserved name of the female dedicant, one can read $\mathrm{M \eta \tau}$ $\rho \varepsilon \grave{~} \Theta \varepsilon \tilde{\omega} v \varepsilon[\dot{0}]|\xi \alpha \mu \varepsilon \dot{\varepsilon} v \eta, \delta \tilde{\omega}| \rho \circ v]$.

121) O. TRIBUlato, "Phoenician Lions. The Funerary Stele of the Phoenician Shem/ Antipatros", Hesperia 82 (2013), p. 459-486 [BE 2014, 35]: An Athenian funerary stele (IG $\mathrm{II}^{2}$ 8388; CEG 596; early 3rd cent.) with a bilingual Greek/Phoenician epitaph and a Greek epigram is decorated with an image that has puzzled scholars. A dead man is lying on a bed; a lion attacks the corpse from the left, while a man (on the right) defends it; the prow of a ship is depicted behind the man. The epigram explains the scene: 'Let no one wonder at this image - that on one side of me a lion and on the other a prow are stretched out. For a hateful lion came, wishing to scatter my things around. But friends came to the rescue and built me a tomb here, those whom, in my love, I desired [should rescue and bury me], coming from a sacred ship. I left Phoenicia and I am, in body, here hidden in earth.' T. proposes a symbolic interpretation of the relief and the text, adducing Near Eastern ideas about the afterlife. In her interpretation, the image alludes to the fear that if the Phoenician man's remains did not receive proper burial, his soul would be condemned to an unhappy fate in the underworld; the naked man grappling with the lion reflects Oriental ideas about a death-fighting god or hero, and the ship to the perception of death as a voyage by ship from this world to the next.

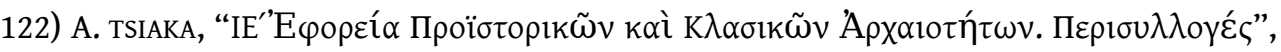
AD 63 B1 (2008) [2014], p. 712: Ed. pr. of two inscriptions delivered to the Museum of Larisa. An epitaph from Argissa is dedicated to Hermes Chthonios (3rd/2nd cent.). A stele from Larisa is inscribed with a dedication to Zeus Homoloios (undated).

123) N. TÜNER ÖNEN, "Hadrians Reisem im östlichen Mittelmeer anhand neuer Inschriften aus Phaselis", Adalya 16 (2013), p. 93-106 [BE 2014, 457]: Ed. pr. of dedications to Hadrian and Sabina Hera Sebaste (1), Thea Matidia (2), and Hadrian (3) from Phaselis.

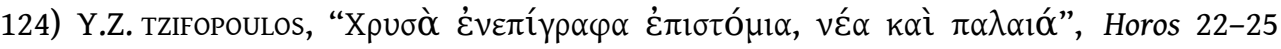
(2010-2013) [2014], p. 351-356: Ed. pr. of a new Hellenistic Orphic lamella from Crete, probably from one of the cemeteries of Eleutherna. The gold tablet is inscribed with a

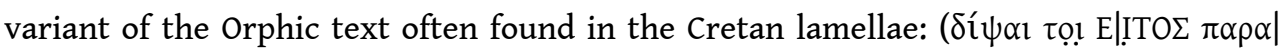

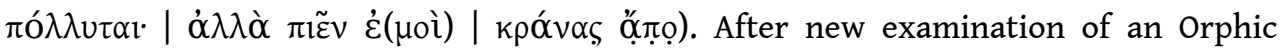
lamella from Methone (SEG XL 541), T. observes that the scribe corrected the name of

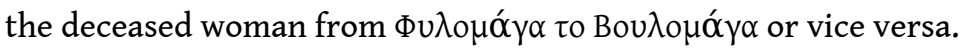

125) H. UZunoĞLu, E. TAşDELEN, “Parerga zum Stadiasmus Patarensis (14): Die Strecken 35 (Arykanda-Arneai) und 37 (Arykanda-Lesei)", Tekmeria 10 (2013) p. 121-131: Ed. pr. of an epitaph which mentions a slave appointed by her mistress as caretaker of her grave and that of her husband (Yeşilköy, territory of Arykanda, 3rd cent. CE; 'A $\mu \nu \mu o ́ v \eta \dot{\eta} \dot{\eta}[\gamma] \mid$

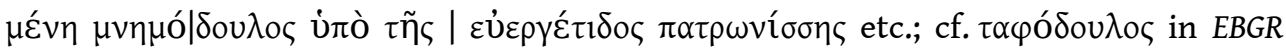
2012, 63). [In addition to receiving a payment for her service, Amymone must have been freed after her master's death; this explains the reference to her mistress as her 'patron'].

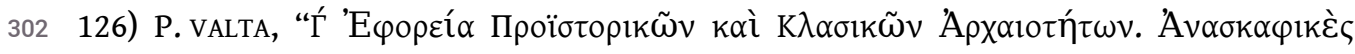

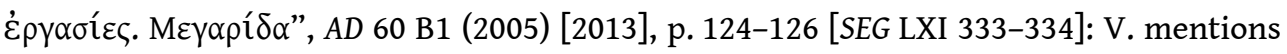
two epigraphic finds from the area of Megara (124 f.): the fragment of an inscribed vase 


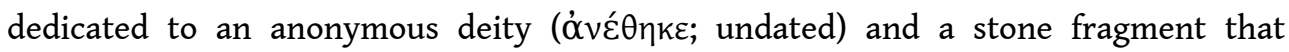
mentions Apollo Apotropaios (undated).

127) R. waGman, "From Song to Monument: Sacred Poetry and Religious Revival in Roman Epidaurus", in Hymnes, p. 219-231: W. examines the hymns that were inscribed in Epidauros between the 2nd and 3rd cent. and the possible reasons for the creation of this epigraphic collection of old musical compositions. The hymns, composed at different times and for different occasions, praise Hygieia and Pallas Athena, and probably Asklepios and Apollo (IG IV ${ }^{2} .1 .129-135$; SEG XXX 390). They were collected from various sources (inscriptions, tablets, papyri) and reinscribed, probably in order to promote the sanctuary's reputation. W. suggests that the dossier was inscribed in the hestiatorion, in whose central court a roofed music hall was built in the late 2nd cent. CE - a time in which interest in ancient traditions was fervent. In an appendix (p. 229-231), W. presents the Greek texts.

128) M.B. WALBANK, "Greek Inscriptions from the Athenian Agora", Hesperia 82 (2013), p. 301-339 [BE 2014, 155]: Ed. pr. of 25 small fragments of inscriptions, mostly leases, inventories, and other financial documents (Athenian Agora). $\mathrm{N}^{\circ} 9$ (lease?, 4th/3rd

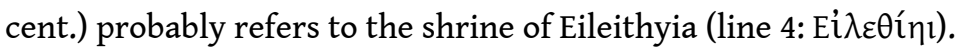

129) A.V. WALSER, "Kaiserzeitliche und frühbyzantinische Inschriften aus der Region von Germia in Nordwestgalatien", Chiron 43 (2013), p. 527-619 [BE 2014, 481, 581; SEG LXI 1102]: W. presents 43 inscriptions from the area of Germia, mostly inedita (cf. id., in P. NIEWÖHNER et alii, "Bronze Age Hüyüks, Iron Age Hilltop Forts, Roman Poleis, and Byzantine Pilgrimage in Germia and its Vicinity", Anatolian Studies 63 [2013], p. 106 f.). 5 texts are of religious interest (2nd/3rd cent.). A freedman made a dedication to Kyrios

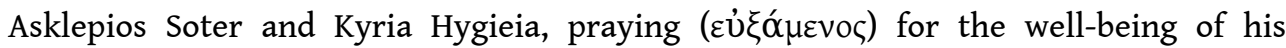
master, his own, and that of his family (6). An alumna and two men made dedications to

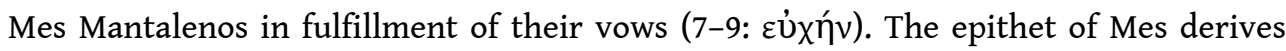
from the village Mantalos, which may be located near Ayvali, where the three dedications were found. W. presents an improved edition of an altar dedicated to

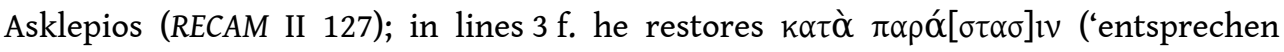
seiner Erscheinung'; cf. TAM V.1.361) [the dedication was probably made after a dream;

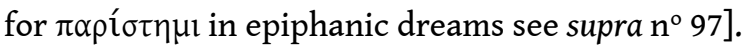

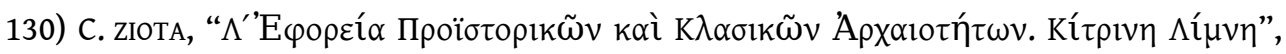
AD 62 B2 (2007) [2014], p. 1001-1007: Ed. pr. a marble statuette of an eagle dedicated by

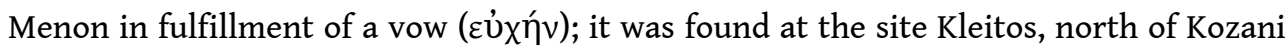
(Imperial period, p. 1005). Statuettes of eagles are a common dedication to Zeus Hypsistos. 


\section{AUTHOR}

\section{ANGELOS CHANIOTIS}

School of Historical Studies

Institute for Advanced Study

Einstein Drive

Princeton, NJ 08540

achaniotis@ias.edu 